\title{
Settling Accounts: The Duty To Prosecute Human Rights Violations of a Prior Regime
}

\author{
Diane F. Orentlicher $\dagger$
}

CONTENTS

INTRODUCTION

I. Why PUNISH?

A. The Case for Prosecutions 2542

B. The Case Against Prosecutions 2544

C. The Role of International Law 2546

II. The Duty To Punish Under CuRrent International LaW 2551

A. International Criminal Law 2552

1. General Principles - 2552

2. Human Rights Crimes 2555

a. The Nuremberg Precedent 2555

b. Post-Nuremberg Developments 2558

c. Domestic Enforcement 2560

$\dagger$ General Counsel, International League for Human Rights; Adjunct Professor, Graduate School of Business, Columbia University. The author is grateful to the Jacob Blaustein Institute for the Advancement of Human Rights, the John D. and Catherine T. MacArthur Foundation, and the Orville H. Schell, Jr. Center for International Human Rights of Yale Law School for supporting the research and writing of this Article. I am grateful, as well, for invaluable comments on earlier drafts of this Article and for other contributions by Floyd Abrams, Nicolas Bratza, Anne-Marie Burley, Roger S. Clark, Owen M. Fiss, Marvin E. Frankel, Alejandro M. Garro, Henry B. Hansmann, Louis Henkin, Paul W. Kahn, John J. Keller, Harold H. Koh, Theodor Meron, Herman I. Orentlicher, and Donna J. Sullivan, and by participants in a faculty workshop at the Yale Law School. Special thanks are owed to Robert K. Goldman, who generously shared research material as well as thoughtful insights and unfailing encouragement throughout the research and writing of this Article, and to Edwin B. Rekosh and George C. Rogers, who provided invaluable assistance in researching voluminous records of the preparatory work of conventions analyzed in this Article. I am also grateful to Drew S. Days, III and other members of the faculty of Yale Law School for countless forms of support and encouragement during academic year 1989-90, when I undertook the research and writing of this Article as the Orville H. Schell, Jr. Fellow: and to the students in my Fall 1989 seminar on Human Rights and Democratic Transitions, whose penetrating insights deepened my understanding of the complex dilemmas faced by transitional societies. And finally, I am indebted to numerous colleagues who have played a central part in fashioning their nations' responses to legacies of state violence for sharing their insights and for urging me to undertake this study. I am honored by their confidence and have been enriched by their friendship. 
B. Human Rights Conventions Specifying a Duty to Prosecute 2562

1. The Genocide Convention 2563

2. The Convention Against Torture 2566

C. Comprehensive Human Rights Conventions 2568

1. International Covenant on Civil and Political Rights 2569

a. Torture 2572

b. Extra-legal Executions 2573

c. Disappearances 2574

2. American Convention on Human Rights 2576

3. European Convention for the Protection of Human Rights and Fundamental Freedoms

D. Customary Law: Disappearances, Extra-legal Executions and Torture

E. Customary Law: Crimes Against Humanity 2585

1. Definition of Crimes Against Humanity 2587

2. Punishment: Permissive or Obligatory? 2593

3. Enduring Significance of Crimes Against Humanity 2594

III. Application of General Rule To Transitional Societies 2595

A. Mitigating the Burden $\quad 2596$

1. Application of Customary International Law 2599

2. Application of Comprehensive Human Rights Conventions 2599

3. Selection Criteria $\quad 2602$

4. Amnesty vs. Pardon 2604

B. Derogation $\quad 2607$

IV. FUTURE DEVELOPMENTS IN THE LAW 2613

$\begin{array}{ll}\text { CONCLUSION } & 2615\end{array}$ 
When we neither punish nor reproach evildoers, we are not simply protecting their trivial old age, we are thereby ripping the foundations of justice from beneath new generations.

\section{A. Solzhenitsyn ${ }^{1}$}

\section{INTRODUCTION}

From Latin America to Asia, from Eastern Europe to Africa, long-entrenched dictatorships have given way to elected civilian governments. ${ }^{2}$ The trend has been sweeping and, at times, astonishing. The outcome of recent transitions cannot yet be known, but it is now clear that nations emerging from dictatorship face formidable challenges as they seek to establish or restore the rule of law.

Many of the new governments replaced regimes responsible for brutal crimes-forced "disappearances," political killings and torture-inflicted on a staggering scale and with wholesale impunity. Whether these crimes should be prosecuted has loomed as one of the most urgent, and agonizing, issues confronting the nascent democracies. In some instances, security forces responsible for the worst abuses retain substantial power, and make clear that they will not brook any legal accounting. ${ }^{3}$ In several countries, governments have responded by granting de facto impunity; in others, the military has insisted upon amnesties which are designed, as one writer has observed, "to enforce a total amnesia regarding [its] crimes." With a tenuous grip on power, some of the fledgling democracies have been presented with a Hobson's choice between their very survival and the principles upon which their existence was founded. How to balance the demands of justice against the continued dangers of military or other force presents issues to which no one has yet proposed generally satisfactory resolutions.

While sharply divided over what policy would best promote a democratic transition, commentators agree on the importance of identifying relevant

1. The GUlag ARChipelago 178 (T. Whitney trans. 1974).

2. Examples include Uruguay, Chile, Argentina, Brazil, Peru, Bolivia, Honduras, El Salvador, Guatemala, Haiti, Nicaragua, Panama, Uganda, Zimbabwe, Namibia, Benin, the Philippines, South Korea, Nepal, Hungary, Poland, Czechoslovakia, Romania, the former German Democratic Republic, Albania, Bulgaria, and Turkey. Significant liberalization, typically a precursor to the establishment of democratic government, has begun in various other countries, including the U.S.S.R. and many African nations.

3. For example, when, after 16 years of military rule, General Augusto Pinochet prepared to turn the Chilean government over to an elected civilian president, he warned: "No one is going to touch my people. The day they do, the state of law will come to an end." AMERICAS WATCH, CHILE IN TRANSITION: HUMAN RIGHTS SINCE THE PLEBISCITE 1988-1989, at 73 (1989) [hereinafter AMERICAS WATCH CHILE REPORT]. In some Eastern European countries, remnants of the Communist Party, although recently removed from office, continue to exercise some autonomous power.

4. Weschler, Aftenword, JUSTICE AND SOC'Y PROGRAM OF THE ASPEN INST,, STATE CRIMES: PUNISHMENT OR PARDON 92 (1989) [hereinafter ASPEN INSTITUTE REPORT]. 
principles of international law. ${ }^{5}$ Are amnesty laws permissible? Does international law impose any affirmative duties to punish human rights violations? If so, are there any principles of law that "mitigate" the general duties in light of the peculiar constraints prevailing in transitional societies? To the extent that current law is not dispositive, is new law desirable? In addressing these questions, I will propose a resolution of critical aspects of the policy debate through the elucidation of principles of international law heretofore misunderstood, ignored, or simply unexamined.

I will argue (in Part I) that the central importance of the rule of law in civilized societies requires, within defined but principled limits, prosecution of especially atrocious crimes. I will also argue that international law itself helps assure the survival of fragile democracies when its clear pronouncement removes certain atrocious crimes from the provincial realm of a country's internal politics and thereby places those crimes squarely within the scope of universal concern and the conscience of all civilized people.

I next argue (in Part II) that recently developed principles of international law, both customary ${ }^{6}$ and conventional, already impose significant obligations in this regard. The most important conclusion in the sections analyzing conventional law is that three comprehensive human rights treaties that do not explicitly require States Parties to prosecute violations nonetheless impose a general duty to investigate allegations of torture, extra-legal killings, and forced disappearances, and, subject to evidentiary and other legitimate constraints, to prosecute those who are responsible. A state's complete failure to punish repeated or notorious instances of these offenses violates its obligations under customary international law.

These duties represent a departure from the traditional approach of international human rights law. While it has long been recognized that international law requires states to respect and ensure human rights, that same law has gener-

5. See, e.g., A. Henkin, Conference Report, in ASPEN INSTTTUTE REPORT, supra note 4, at 1-2. Identification of relevant international legal standards will become increasingly important as challenges to amnesty laws are considered by international bodies that supervise states' compliance with human rights conventions. Challenges to amnesty laws enacted in Argentina, El Salvador, Suriname, and Uruguay have been lodged with the Inter-American Commission on Human Rights of the Organization of American States. The Commission has requested the Inter-American Court to accept a case challenging Suriname's amnesty law. Case 10.150, Informe 3/90, OEA/ser.L./V/II.77, doc. 23 (1990). Although the issue of accountability for past abuses has generated rich discussion, there has been relatively little analysis to date of applicable rules of international law. But see Goldman, International Law and Amnesty Laws, HUM. RTS. INTERNET REP., Winter 1988, at 9; Rogers, Argentina's Obligation to Prosecute Military Officials for Torture, 20 COLUM. HUM. RTS. L. REV. 259 (1989); Roht-Arriaza, State Responsibility to Investigate and Prosecute Grave Human Rights Violations in International Law, 78 CALIF. L. REV. 451 (1990); J. Terry, Domestic Amnesties for Violators of International Human Rights: Sketching a Framework for International Legal Regulation (May 19, 1989) (unpublished manuscript on file with author).

6. Customary international law, which is binding on all states, arises from "a general and consistent practice of states followed by them from a sense of legal obligation." RESTATEMENT (THIRD) OF THE FOREIGN RELATIONS LAW OF THE UNITED STATES $§ 102(2)$ (1987) [hereinafter RESTATEMENT (THIRD)]; see also Statute of the International Court of Justice, art. 38(1)(b), 59 Stat. 1055, 1060 (1945) (sources of international law applied by Court include "international custom, as evidence of a general practice accepted as law"). 
ally allowed governments to determine how their obligations will be fulfilled. But the measures used to secure human rights are no longer subject to the broad discretion of governments when it comes to a core set of fundamental rights that merit special protection. When torture, disappearances, and illegal killings occur, governments must make good-faith efforts to bring the wrongdoers to justice.

I next consider (in Part III) whether successor governments must prosecute all such offenses committed by a previous regime. ${ }^{7}$ Analyzing the duties in light of their underlying rationales, I conclude that both the treaty and customary obligations to punish atrocious crimes are consistent with a limited program of prosecutions, but would be breached by wholesale impunity. Prosecutions of those most responsible for designing and implementing a past system of state violence or for the most notorious violations would best comport with common standards of justice.

Finally, I consider (in Part IV) whether new law clarifying governments' obligation to punish atrocious crimes should be developed. I support the current trend, evident in recent human rights instruments, toward specifying a duty to prosecute grave violations of physical integrity, and urge that future conventions should establish procedural measures enabling victims of such crimes (or their survivors) to act to ensure prosecution.

\section{WHY PUNISH?}

The debate over post-transition prosecutions ${ }^{8}$ has focused on their potential role in ending cycles of state violence and promoting consolidation of demo-

7. The legal analysis assumes that the violations were committed in the recent past, and does not consider whether the passage of time could extinguish a duty to prosecute atrocious crimes. But see infra notes $126,252$.

8. Human rights professionals have figured most prominently in the public debate. Other participants have included journalists, academics, and political leaders. While divided on many issues, commentators agree on two points. First, prosecutions for past crimes must accord with internationally recognized standards of due process. The potential for abuse of the prosecution power-underscored by the summary trial and execution of former Romanian leader Nicolae Ceausescu and his wife in December 1989-is cause for concern even for those who generally favor prosecutions. Second, some crimes must be punished pursuant to international law-a point conceded by those who oppose development of new law requiring governments to prosecute abuses of predecessor regimes. See, e.g., Zalaquett, Confronting Human Rights Violations Committed by Former Governments: Principles Applicable and Political Constraints, in ASPEN INSTITUTE REPORT, supra note 4, at 35, 41-42. There appears, however, to be a significant gap between existing law requiring punishment and general perceptions of the law. Many analysts have assumed that international law places few restraints on a government's discretion regarding punishment of a prior regime's crimes. See, e.g., id. at 41-42; R. Teitel, How Are the New Democracies of the Southern Cone Dealing With the Legacy of Past Human Rights Abuses? (May 10, 1990) (unpublished discussion paper prepared for Council on Foreign Relations, Latin America Project, Issue Series \#3); Transitions to Democracy and the Rule of Law, 5 AM. U.J. INT'L L. \& POL'Y 965, 1080-81 (1990). In fact, however, current law imposes rather significant requirements regarding punishment of atrocious crimes. See infra Part II. A chief reason for this gap is that key sources of a duty to prosecute human rights crimes include conventions that do not explicitly require States Parties to punish violations, but which have authoritatively been interpreted to do so. Looking only at the text of the conventions, many have assumed that the treaties have no bearing on the question of punishment. 
cratic transitions. These considerations have, in turn, informed a broader debate about the role that international law should play in shaping governments' policy toward violations of a prior regime.

\section{A. The Case for Prosecutions}

The fulcrum of the case for criminal punishment is that it is the most effective insurance against future repression. ${ }^{9}$ By laying bare the truth about violations of the past and condemning them, prosecutions can deter potential lawbreakers and inoculate the public against future temptation to be complicit in state-sponsored violence. ${ }^{10}$ Trials may, as well, inspire societies that are reexamining their basic values to affirm the fundamental principles of respect for the rule of law and for the inherent dignity of individuals. ${ }^{11}$

Above all, however, the case for prosecutions turns on the consequences of failing to punish atrocious crimes committed by a prior regime on a sweeping scale. If law is unavailable to punish widespread brutality of the recent past, what lesson can be offered for the future? A complete failure of enforcement vitiates the authority of law itself, sapping its power to deter proscribed conduct. ${ }^{12}$ This may be tolerable when the law or the crime is of marginal consequence, but there can be no scope for eviscerating wholesale laws that forbid violence and that have been violated on a massive scale. ${ }^{13}$ Societies recently scourged by lawlessness need look no farther than their own past to discover the costs of impunity. Their history provides sobering cause to believe, with William Pitt, that tyranny begins where law ends.

9. See Garro \& Dahl, Legal Accountability for Human Rights Violations in Argentina: One Step Forward and Two Steps Backward, 8 HuM. RTs. L.J. 283, 343 (1987); Malamud-Goti, Transitional Governments in the Breach: Why Punish State Criminals?, 12 HUM. RTS. Q. 1, 12 (1990). It might be objected that punishment of past crimes cannot be justified as necessary to deter future conduct. See $\mathrm{R}$. Teitel, supra note 8 , at 7,9. But it is precisely by imposing penalties after a crime has occurred-when it is too late to deter the sanctioned conduct-that criminal law attempts to ensure future lawful behavior. See Fingarette, Rethinking Criminal Law Excuses, 89 YALE L.J. 1002, 1013-16 (1980).

10. In this respect, Malamud-Goti asserts, post-transition prosecutions "address]] the community as well as the potential offender, creating incentives for citizens to withdraw support from potential dictatorial regimes." Malamud-Goti, Trying Violators of Human Rights: The Dilemma of Transitional Democratic Governments, in ASPEN INSTTUUTE REPORT, supra note 4, at 82; $f f$. O. KIRCHHELMER, POLITICAL JUSTICE 336 (1961).

11. Citing Hannah Arendt's view that "the first step on the road to total domination is to kill the juridicial person in man," David Remnick, the Moscow correspondent for The Washington Post, has observed: "Likewise, the first essential step toward liberty is the revival of the legal impulse in man." $L$. WESCHLER, A MIRACLE, A UNIVERSE 242 (1990) (quoting Remnick).

12. Cf. H. PACKER, THE LIMITS OF THE CRIMINAL SANCTION 287 (1968) ("respect for law generally is likely to suffer if it is widely known that certain kinds of conduct, although nominally criminal, can be practiced with relative impunity"); Fingarette, supra note 9, at 1014 (unless society imposes a sanction when its laws are violated, the law "becomes functionally a mere appeal"; "the concept of law as a requirement becomes unintelligible") (emphasis in original).

13. A paramount function of law-and, indeed, of government-is to protect citizens from harm, particulary physical violence. See J. LOCKE, II TWO TREATISES OF GOVERNMENT ๆI 127-131 (G. Rutledge ed. 1857); R. POUND, SOCIAL CONTROL THROUGH LAW 25 (1942). 
The harmful effects of impunity are compounded when prosecutions are foreclosed by an amnesty law ${ }^{14}$ enacted by, or to appease, the military or other autonomous sectors. For "[t]he essential precondition for the effectiveness of law ... is that it shall display an independence from gross manipulation and shall seem to be just. It cannot seem to be so without upholding its own ... criteria of equity ...."15

Some proponents believe that governments should prosecute their predecessors' atrocious crimes because the trials can advance a nation's transition to democracy. ${ }^{16}$ By demonstrating that no sector is above the law, prosecutions of state crimes can foster respect for democratic institutions and thereby deepen a society's democratic culture. ${ }^{17}$ Conversely, because law "is located in our myths and stories as a powerful attribute of legitimate authority,"18 failure to enforce the law may undermine the legitimacy of a new government and breed cynicism toward civilian institutions.

Some analysts urge that prosecutions strengthen fragile democracies because the rule of law is integral to democracy itself. ${ }^{19}$ This argument has several strands: Enforcement of legal safeguards against arbitrary state action is essential to the full exercise of political rights. ${ }^{20}$ Moreover capitulations to military demands for impunity reflect, and may enhance, the military's capacity to exercise a veto power over government policies, thereby vitiating the sover-

14. The term "amnesty" usually refers to an official act prospectively barring criminal prosecutions, and is often contrasted with pardons, which typically exempt convicted criminals from serving their sentences, in whole or in part, without expunging the conviction. But these distinctions are inexact; pardons, like amnesties, can be used to foreclose prosecutions, and amnesties sometimes cover persons serving prison terms. See A. DAMICO, DEMOCRACY AND THE CASE FOR AMNESTY 5 (1975); K. MOORE, PARDONS: JUSTICE, MERCY AND THE PUBLIC INTEREST 4-5 (1989). The word "amnesty"-like "amnesia"-derives from the Greek "amnestia," which means "forgetfulness" or "oblivion"; an amnesty constitutes a declaration that the government intends to obliterate (and not merely forgive) a crime. See K. Moore, supra, at 5; Goldman, Amnesty Laws, International Law and the American Convention on Human Rights, 6 THE LAW GROUP DOCKET 1, 3 (1989) (citing BLACK's LAW DICTIONARY definition of amnesty as "the abolition and forgetfulness of the offense," while "pardon is forgiveness").

15. E. P. THOMPSON, WHIGS AND HUNTERS 263 (1975). A popular conception of the rule of law is that a system of law replaces a private system of force. See K. DAVIS, DISCRETIONARY JUSTICE 28 (1969). Measured against this ideal, paralysis of legal institutions by an illegitimate threat of force is the very antithesis of the rule of law.

16. E.g., Malamud-Goti, supra note 10 , at 81 .

17. See id.; Garro \& Dahl, supra note 9, at 344. The Alfonsin government's prosecution of former junta leaders for human rights violations had a profound effect on Argentine society. Many Argentines felt enormous pride at their accomplishment in asserting the rule of law over former generals who had led the country during a period of sweeping state violence. (I am indebted to Professor Owen Fiss of Yale Law School for bringing this to my attention.)

18. Cover, The Folktales of Justice: Tales of Jurisdiction, 14 CAP. U.L. REv. 179, 180 n.7.

19. Professor Dahl, in contrast, asserts that it is theoretically possible for a country to be democratic without respecting the rule of law. He believes, nonetheless, that the political culture that supports stable democracies is also likely to give rise to a high public valuation of principles of fairness, legality and due process. R. Dahl, Democracy and Human Rights Under Different Conditions of Development 3 (June 20-23, 1988) (paper prepared for the Nobel Symposium on Human Rights).

20. $C f$. S. Huntington, The Modest Meaning of Democracy 14 (Nov. 18, 1986) (consultation paper prepared for Carter Center of Emory University Conference, Atlanta, Ga.) (harassment and jailing of political opponents are incompatible with democracy). 
eignty of the national polity. ${ }^{21}$ In contrast, when a government prosecutes military personnel for human rights violations, it affirms the supremacy of publicly accountable civilian institutions. ${ }^{22}$

Because the values secured by trials are crucially important and the harmful effects of impunity substantial, proponents of punishment believe that the authority of international law should be brought to bear to assure prosecution of atrocious crimes. Further, to the extent that a deterrence rationale justifies prosecution of state crimes, the underlying objective is best served when international law precludes the possibility of impunity. ${ }^{23}$

\section{B. The Case Against Prosecutions}

The chief argument against a general rule requiring prosecutions is that fragile democracies may not be able to survive the destabilizing effects of politically charged trials. ${ }^{24}$ Many countries emerging from dictatorship are polarized and unstable, ${ }^{25}$ and may be further fractured by prosecutions of the prior regime's depredations. Under these circumstances, some urge, democratic consoli-

21. See AMERICAS WATCh, ASIA WATCH, HELSINKI WATCH \& THE LAWYERS COMMTTEE FOR HUMAN RIGHTS, THE REAGAN ADMINISTRATION'S RECORD ON HUMAN RIGHTS IN 1987, at 2 (1987) [hereinafter 1987 REAGaN ReviEw]; Petras, Getting Away with Murder, N.Y. Times, Sept. 7, 1990, at A27, col. 2 (as long as Chilean armed forces determine "when and where and against whom laws will apply, Chile does not measure up to any internationally accepted standard of democracy"); L. Whitehead, The Consolidation of Fragile Democracies: A Discussion with Illustrations 26-28 (Nov. 18, 1986) (consultation paper prepared for Carter Center of Emory University Conference, Atlanta, $\mathrm{Ga}$.) (there can be no meaningful consolidation of democracy when a civilian government has to assure the military that human rights prosecutions will not be pursued).

22. Proponents also believe that prosecutions contribute to the rehabilitation of victims of past violations and, indeed, of society itself. Human rights activist Aryeh Neier asserts that punishment fulfills society's duty "to honor and redeem the suffering of the individual victim." L. WESCHLER, supra note 11, at 244; see also Neier, What Should Be Done About the Guilty?, N.Y. REv. BooKs, Feb. 1, 1990, at 34. Finally, some advocates of prosecutions assert claims of an absolute duty, based upon fundamental conceptions of justice, to punish atrocious crimes. See, e.g., Mignone, Estlund \& Issacharoff, Dictatorship on Trial: Prosecution of Human Rights Violations in Argentina, 10 YALE J. INT'L L. 118, 149 \& n.119 (1984). See generally $\mathrm{R}$. Teitel, supra note 8.

23. I am indebted to Professor Alan Schwartz of Yale Law School for this insight. Cf. H. PACKER, supra note 12, at 64 ("If people are to be deterred from engaging in criminal conduct by the punishment of those who have done so in the past, it is important that the imposition of punishment be as nearly certain as possible.").

24. See Zalaquett, supra note 8, at 27-28. A government's ability to prosecute a prior regime's abuses is partly a function of the circumstances of the political transition. The widest scope for punishment exists when the transition was brought about by external conquest, as happened in post-war Germany and Japan. Less latitude for punishment exists if a retreating military has been discredited but still retains autonomous power, and still less if the military relinquishes power to civilians when it could remain in power indefinitely, and thus is in a position to dictate the terms of a transition. See id. at 46-47; see also Stepan, Paths Toward Redemocratization: Theoretical and Comparative Considerations, in TRANSITIONS FROM AUTHORITARIAN Rule: COMPARATIVE PersPectives 64 (G. O'Donnell, P. Schmitter \& L. Whitehead eds. 1986).

25. This is particularly true of countries, like the Philippines, Chile, Argentina, and Uruguay, in which the armed forces committed grave violations against sectors perceived as political opponents of the state. 
dation can be furthered by implementing a policy of reconciliation embodied in an amnesty law covering past violations. ${ }^{26}$

In countries where the military retains substantial power after relinquishing office, efforts to prosecute past violations may provoke rebellions ${ }^{27}$ or other confrontations that could weaken the authority of the civilian government. ${ }^{28}$ And in countries where security forces have retained modest power relative to an elected government, prosecutions may induce the military to "close ranks." 29 In these circumstances, prosecutions could reinforce the military's propensity to challenge democratic institutions. ${ }^{30}$

In light of these constraints, some analysts believe that democratic consolidation may be best served if a precarious government stays the hand of prosecution. Their argument rests, in large measure, on the claim that transitional societies may not yet possess the attributes of a viable democracy-in particu-

26. E.g., Zalaquett, supra note 8, at 37-38; Lewis, Revenge or Reconciliation?, N.Y. Times, Apr. 10, 1990, at A21, col. 4. Uruguayan President Julio Maria Sanguinetti justified an amnesty law covering abuses of a previous military regime on this basis:

The Uruguayan government has decided to take measures of magnanimity or clemency utilizing

a mechanism provided for in the Constitution of the Republic (the amnesty). The 12 years of

dictatorship have left scars which will need a long time to heal and it is good to begin to do so.

The country needs reconciliation to face a difficult but promising future.

Letter from President Sanguinetti to Amnesty International (Mar. 31, 1987), reprinted in AMNESTY INTERNATIONAL, URUGUAY: LEgISLATION DEALING WTTH PAST HUMAN RIGHTS VIOLATIONS, app. at 2 (1987), AI Index: AMR 52/02/87. For a contrasting view, see The Administration of Justice and the Human Rights of Detainees, Question of the Human Rights of Persons Subjected to any Form of Detention or Imprisonment, Study on Amnesty Laws and Their Role in the Safeguard and Promotion of Human Rights, 37 U.N. ESCOR Comm'n on Hum. Rts. at 9, para. 35, U.N. Doc. E/CN.4/Sub.2/1984/15 [hereinafter U.N. Study on Amnesty Laws) (Special Rapporteur asserts that "an amnesty covering persons guilty of conduct involving a serious infringement of human dignity ..., far from encouraging national reconciliation, would only increase tension ....").

27. Dissatisfaction with prosecutions of military officers for past human rights violations was a key factor in three rebellions against the government of Argentine President Raull Alfonsín. See Argentine Departs, Democracy Hardly Bankrupt, N.Y. Times, July 8, 1989, at 2, col. 1; Revolt by 400 Argentine Troops Quelled, N.Y. Times, Dec. 3, 1988, at 3, col. 4. The Argentine military was prepared to accept prosecution of its leaders, but some factions rebelled when the scope of prosecutions broadened. See infra text accompanying note 271 . The experience of other countries tends to refute the claim that impunity can secure military acceptance of civilian rule. Emboldened by impunity, the military has continued to assert control over the civilian governments of El Salvador, Guatemala, Haiti, and the Philippines; military factions have launched coup attempts against the civilian governments in Guatemala, Haiti, and the Philippines.

28. A civilian government may risk a humiliating challenge to its authority if it seeks to bring a recalcitrant military to account. This happened when Uruguayan courts summoned military defendants to appear before them to answer charges relating to rights violations committed in the 1970's. In late 1986, in the face of reports that the defendants would not respond to the summonses, the government of Uruguayan President Julio María Sanguinetti hastily pushed through Congress an amnesty law covering the controverted prosecutions, thereby seeking to avert a challenge to the supremacy of civilian institutions which the government was not prepared to face. See AMERICAS WATCH, CHALLENGING IMPUNITY: THE LEY DE CADUCIDAD AND THE REFERENDUM CAMPAIGN IN URUGUAY 14-15 (1989) [hereinafter AMERICAS WATCH URUGUAY REPORT].

29. Prosecutions of military leaders undertaken by the government of Argentine President Raúl Alfonsín are believed to have had this effect, reinforcing the military's tendency to operate autonomously. See Malamud-Goti, supra note 9, at 13; Zalaquett, supra note 8, at 57.

30. For a general analysis of the threat to democratization posed by various dimensions of military "prerogatives," see A. STEPAN, RETHINKING MLLTARY POLITICS 68-92 (1988). 
lar, the new governments may lack the power to bring the military to account $^{31}$ - and holds that the international community should not press these governments to act as though they were fully consolidated when in fact the transition process has only begun. Stripped to its essence, their argument is one of lesser evils. Opponents of law requiring prosecutions concede that impunity erodes the rule of law. But, they argue, if a fragile democratic government institutes prosecutions, it may provoke its overthrow by sectors that are illdisposed to respect human rights. ${ }^{32}$

\section{The Role of International Law}

As thus framed, the policy debate has tended to view the imperatives of the rule of law as somehow fundamentally at odds with political reality. This approach is unwarranted. The law itself can accommodate the constraints sur-

31. See L. Moreno Ocampo, About the Trials and Punishment of the Massive Violations of Human Rights in Argentina \$ 2.1.1 (Mar. 4-8, 1990) (paper prepared for conference on the Transition to Democracy in Argentina, Yale Law School, New Haven, Conn.); Zalaquett, supra note 8, at 27-28.

32. Still, opponents of prosecutions concede that a successor government cannot ignore the legacy of dictatorship; a policy that meaningfully addresses past violations is necessary in order to draw a line between the past and present, and to enable a scarred society to come to terms with its past so that it can begin the process of healing. For this reason, even those who oppose prosecutions believe that governments that succeed regimes responsible for atrocious and widespread abuses should investigate and officially acknowledge the violations. See ASPEN INSTITUTE REPORT, supra note 4, at 4-5; Zalaquett, supra note 8, at 30-34. Many of the arguments advanced in support of an official accounting echo justifications voiced in support of prosecutions. Like prosecutions, an official account of past violations serves an exemplary function, stigmatizes those responsible for atrocious crimes, and, by illuminating the sphere of darkness in which abuses can proliferate, prevents future violations. Because the objectives served by an official truthtelling process resemble those associated with punishment, some analysts have suggested that the former might obviate, or at any rate diminish, the perceived need for prosecutions. See R. Teitel, supra note 8, at 11-12.

Whatever salutary effects it can produce, an official truthtelling process is no substitute for enforcement of criminal law through prosecutions. Indeed, to the extent that such an undertaking purports to replace criminal punishment (rather than to promote distinct goals that punishment cannot serve), it diminishes the authority of the legal process; it implicitly concedes that the machinery of justice is powerless to punish even those crimes that any civilized society views as most pernicious. Further, the most authoritative rendering of the truth is possible only as a result of judicial inquiry, and major prosecutions can generate a comprehensive record of past violations. Cf. Report to the President from Justice Robert H. Jackson, Chief of Counsel for the United States in the Prosecution of Axis War Criminals. June 7, 1945, reprinted in 39 AM. J. INT'L L. 178, 184 (Supp. 1945) [hereinafter Jackson Report] (stating that basis of case against major war criminals at Nuremberg must be "a well-documented history of what we are convinced was a grand, concerted pattern to incite and commit the aggressions and barbarities which have shocked the world," and asserting, "Unless we write the record of this movement with clarity and precision, we cannot blame the future if in days of peace it finds incredible the accusatory generalities uttered during the war. We must establish incredible events by credible evidence."); FINAL REPORT TO THE SECRETARY OF THE ARMY ON THE NUERNBERG WAR CRIMES TRIALS UNDER CONTROL COUNCIL LAW No. 10 (Aug. 15, 1949) (written by Telford Taylor, Brig. Gen., U.S.A., Chief of Counsel for War Crimes) [hereinafter TAYLOR REPORT] (asserting that "[t]he documents and testimony of the Nuernberg record can be of the greatest value in showing the Germans the truth about the recent past."); R. CONOT, JUSTICE AT NUREMBERG xiii (1983) (quoting Telford Taylor saying at Nuremberg trial, "We cannot here make history over again. But we can see that it is written true."). 
rounding transitional societies while securing crucially important values. ${ }^{33}$ Addressing the dilemma of tenuous democracies through law assures that an appropriate balance is struck between the demands of justice and potentially conflicting values, such as political stability. ${ }^{34}$

The alternative-leaving the decision about prosecution to the unbridled discretion of governments--does nothing to assure the bona fides of their choice. Governments may forego trials to avert a perceived challenge to their authority, however remote or speculative, even if long-term national interests would be better served by prosecutions. ${ }^{35}$ This consideration is by no means hypothetical; although numerous countries have begun transitions from repressive rule to democracy in recent years, relatively few successor governments

33. While an imprecise analogy, U.S. constitutional protection of speech provides an instructive example of how legal standards can protect fundamental rights without imperiling crucial national interests. Speech may be curbed, in narrow circumstances, if it poses an immediate threat to important governmental interests, but U.S. constitutional law protects fundamental values associated with expressive activity by forbidding interference with speech unless the restriction is justified by the appropriate legal standard-whether the "clear and present danger" test first enunciated by Justice Holmes, see Abrams v. United States, 250 U.S. 616, 627-28, 630 (1919) (Holmes, J., dissenting); Schenck v. United States, 249 U.S. 47, 52 (1919); or the "incitement to imminent lawless action" test of Brandenburg v. Ohio, 395 U.S. 444, 447 (1969) (per curiam); or, as in the case of prior restraints on the press, upon proof that publication "will surely result in direct, immediate, and irreparable damage to our Nation or its people," New York Times Co. v. United States, 403 U.S. 713, 730 (1971) (Stewart, J., concurring). While protecting overriding governmental interests, all of these tests seek to assure a free society-even at the risk of making governance a more precarious enterprise. Part III considers how relevant principles of international law can accommodate the constraints faced by societies emerging from dictatorship.

34. International law does this both by prescribing standards of conduct that take account of threats to public order and, at least with respect to conventional law, by establishing an oversight mechanism to ensure good faith compliance with those standards. Multilateral human rights conventions typically establish a body or bodies that are responsible for monitoring States Parties' compliance. These bodies have generally accorded states substantial discretion to determine how they will satisfy their treaty obligations, but nonetheless ensure that governments do not invoke inappropriate excuses for noncompliance. For an example of such treatment under the European Convention for the Protection of Human Rights and Fundamental Freedoms, adopted Nov. 4, 1950, 213 U.N.T.S. 221, Europ. T.S. No. 5 (entered into force Sept. 3, 1953) [hereinafter "European Convention"], see The Greek Case, 1969 Y.B. EUR. CONV. ON HUM. RTS. 71-76, paras. 152-65 (Eur. Comm'n of Hum. Rts.). See generally Higgins, Derogations Under Human Rights Treaties, 48 BRIT. Y.B. INT'L L. 281 (1976-77).

35. See L. WesCHLER, supra note 11, at 244. Cf. Montealegre, The Compatibility of a State Party's Derogation Under Human Rights Conventions with its Obligations Under Protocol II and Common Article 3,33 AM. U.L. REV. 41, 49 (1983) ("the real purpose" of amnesties covering criminal acts committed during internal conflicts, though ostensibly enacted to promote national reconciliation, "is to permit government officials responsible for human rights violations to escape responsibility for their acts"). 
have attempted prosecutions. ${ }^{36}$ While many have asserted that prosecutions were impossible, the claim has typically been overstated. ${ }^{37}$

I am not, of course, suggesting that governments should press prosecutions to the point of provoking their own collapse. Rather, I am suggesting that, by generally requiring prosecutions, international law helps assure that governments do not forego trials simply because it seems politically expedient to do so. A critical distinction to be drawn here is between military insubordination and a challenge that poses a genuine and serious threat to national life. Because trials

36. Amnesty laws or decrees have been adopted, inter alia, in Argentina, Brazil, Chile, Uruguay, Guatemala, El Salvador, Nicaragua, Namibia, and Suriname, and de facto impunity has been conferred in other countries, including the Philippines and Haiti. See LAWYERS COMMITTEE FOR HUMAN RIGHTS, IMPUNITY: PROSECUTIONS OF HUMAN RIGHTS VIOLATIONS IN THE PHILIPPINES (1991); LAWYERS COMMITTEE FOR HUMAN RIGHTS, PAPER LAWS, STEEL BAYONETS: BREAKDOWN OF THE RULE OF LAW IN HATTI (1990). But see 16 Convicted in Philippine Assassination, Wash. Post, Sept. 29, 1990, at A15, col. 1; Top Duvalier Aide, at a Rowdy Trial, Condemned To Die, N.Y. Times, July 17, 1986, at A1, col. 2 (reporting exceptional trials of abuses committed by prior regimes in Philippines and Haiti). Prosecutions for human rights violations by predecessor regimes have been undertaken in Guinea, Nicaragua, and the Central African Republic, see J. Terry, supra note 5, and investigations preparatory to prosecutions have been instituted in Uganda. The governments of several Eastern European countries, including Romania, Bulgaria, Czechoslovakia, Poland, and Germany, have instituted or are considering initiating criminal prosecutions for violent human rights crimes committed before the recent political transitions in those countries. See Upheaval in the East: Army Executes Ceausescu and Wife for "Genocide" Role, Bucharest Says, N.Y. Times, Dec. 26, 1989, at A1, col. 6; Evolution in Europe: Ceausescu's Fallen Heir Faces Court, N.Y. Times, May 27, 1990, at 14, col. 4; Inquiry on Deaths Going Nowhere in Romania, N.Y. Times, Feb. 14, 1991, at A10, col. 1; Czechoslovakia Detains Ex-Communist Party Leader and 4 Others, N.Y. Times, June 7, 1990, at Al0, col. 1; Bulgaria Presses Inquiries into the Communist Past, N.Y. Times, June 6, 1991, at A15, col. 1; Bulgaria's Ousted Dictator Agrees To Face His Accusers, N.Y. Times, July 19, 1990, at A6, col. 5; Poland Arrests 2 Police Generals in '84 Killing of Reformist Priest, N.Y. Times, Oct. 9, 1990, at A8, col. 3; Prosecutors for Unified Germany Seize Former Communist Officials, N.Y. Times, Oct. 7, 1990, at 14, col. 1; Honecker's Arrest Sought in Berlin Wall Shootings, N.Y. Times, Dec. 2, 1990, at 23, col. 1; Honecker Taken to Soviet Union; Germany Demanding His Return, N.Y. Times, Mar. 15, 1991, at A1, col. 1; 4 Ex-Officials of East Germany Arrested, N.Y. Times, May 22, 1991, at A3, col. 4; Berlin Wall Guards Accused of Shooting Escapees, N.Y. Times, June 16, 1991, at 6, col. 1; End of the Line: Leaders at Communism's Finish, N.Y. Times, Nov. 16, 1990, at A16, col. 1 .

37. For example, officials in the government of Philippine President Corazon Aquino justified their failure to prosecute violations committed under the aegis of President Ferdinand Marcos on the basis that the effort would have amounted to "political suicide." A former spokesman for President Aquino explained, "This government had an obligation to survive." Warning: Joining the Bar Is Hazardous to Your Health, FAR E. ECON. REV., Nov. 3, 1988, at 81 . Yet the Aquino government enjoyed considerable power relative to the armed forces in its early months in office, and was at that time in a position to press bold action without provoking a viable threat of military rebellion. Moreover its failure to hold the military to account scarcely assured stability; in its five years in office the Aquino government has weathered seven coup attempts. See D. Orentlicher, The Philippines Experience (Nov. 4-6, 1988) (paper presented at conference on State Crimes: Punishment or Pardon, Aspen Institute for Humanistic Studies, Wye Woods Conference Center).

Experts on Uruguay similarly believe that President Julio María Sanguinetti could have insisted upon some prosecutions of the military for past violations without derailing his country's transition to democracy. E.g., Telephone Interview with Professor Robert Kogod Goldman (May 21, 1990). In August 1984, Uruguay's political parties and the military government entered into a pact governing the terms of a transition to civilian rule. It is generally understood that the parties to the pact agreed that the executive branch of the future government would not initiate prosecutions for rights violations committed under the military government's auspices, but would not interfere with cases already before the courts. In August 1986, President Sanguinetti introduced legislation that would have established a sweeping amnesty for past violations. A different amnesty bill was enacted in December 1986. A subsequent effort to overturn the amnesty by referendum failed to secure the necessary votes. See AMERICAS WATCH URUGUAY REPORT, supra note 28 , at 11-15. 
secure preeminent rights and values, governments should be expected to assume reasonable risks associated with prosecutions, including a risk of military discontent. ${ }^{38}$

If leaving prosecutions to governments' discretion fails to ensure appropriate decisions, it also deprives governments that wish to restore the rule of law of potentially crucial support. International law requiring punishment of atrocious crimes-and, more to the point, international pressure for compliance-can provide a counterweight to pressure from groups seeking impunity. ${ }^{39}$

On the other hand, a virtual certainty of punishment could deter some abusive regimes from voluntarily relinquishing power. On balance, however, this concern is outweighed by the more harmful effects of failing to establish an effective deterrent to systematic violations of fundamental rights, in part because the prospect of facing prosecutions is rarely, if ever, the decisive factor in determining whether a transition will occur. ${ }^{40}$

Further, when prosecutions are undertaken pursuant to international law, they are less likely to be perceived-and opposed-as political revanchism. It is easy to believe that prosecutions are politically motivated when the decision to institute them is a matter of unbridled discretion; justice is readily mistaken for vengeance. ${ }^{41}$ When, however, international law insists upon punishment of atrocious crimes, the prosecutions can, as Otto Kirchheimer said of the Nuremberg prosecutions for crimes against humanity, "define where the realm of politics ends or, rather, is transformed into the concerns of the human condition, the survival of mankind in both its universality and diversity."

38. See Garro \& Dahl, supra note 9, at 343-44; Malamud-Goti, supra note 10 , at 76.

39. This point was underscored by Luis Moreno Ocampo, who in the mid-1980's prosecuted former junta leaders for human rights violations committed in Argentina during the 1970's. Mr. Moreno Ocampo subsequently stated that his work would have been made easier if the government's program of prosecutions had been backed by the weight and authority of international law. (This observation was made during a conference in Buenos Aires on Argentina's transition to democracy, sponsored by the Yale Law School, during October and November 1989, in which the author participated.) Prosecutions based upon international legal obligations-and expectations of their fulfiliment-may, in any event, be less likely to provoke organized opposition than prosecutions the initiation of which is perceived as optional. It is not surprising that outgoing military regimes have mounted strong opposition to prosecutions when the issue was understood to be negotiable. It is less clear that opposition in those circumstances is a reliable indicator of how the military would respond to mandatory prosecutions.

40. In Argentina, for example, the outgoing military regime opposed prosecutions but lacked the power to insist on impunity as a pre-condition to civilian rule. The last of three successive military juntas enacted a "self-amnesty" law, which was nullified by the Alfonsín government. See Garro \& Dahl, supra note 9, at 301, 305-06.

41. For an example of this type of reasoning, see Lewis, Revenge or Reconciliation?, N.Y. Times, Apr. 10, 1990, at A21, col. 4.

42. O. KIRCHHEMER, supra note 10 , at 341 . Kirchheimer's views about the effects of the Nuremberg prosecutions are instructive: "In spite of the Nuremberg trial's infirmities, the feeble beginning of transnational control of the crime against the human condition raises the Nuremberg judgment a notch above the level of political justice by fiat of a successor regime." Id. Precisely because the crimes prosecuted at Nuremberg were made subject to the "control" of international law, the trials helped establish "that the most atrocious offenses against the human condition lie beyond the pale of what may be considered contingent and fortuitous political action, judgment on which may change from regime to regime." Id. 
While helping to "depoliticize" trials of human rights violators, ${ }^{43}$ international law requiring prosecution does not prevent governments from instituting policies of national reconciliation. ${ }^{44}$ The argument that amnesty laws may be necessary to mend social divisions falsely assumes that such laws are the only means of achieving reconciliation. There are other means. ${ }^{45}$ Further, amnesty laws can be used to promote national reconciliation, provided they do not cover atrocious crimes which international law requires states to punish. ${ }^{46}$

By drawing a bright line between crimes that must be punished and those for which amnesties are permissible, international law helps answer an agonizing question confronting many transitional societies: How is it possible to seek accountability without setting off an endless chain of divisive recriminations? Writing of a proposal to purge Communist collaborators from formerly state-run enterprises, Polish Solidarity activist Adam Michnik evokes the dilemma confronting his nation in the wake of the prior regime's collapse:

The struggle for freedom is beautiful. Anyone who has taken part in this struggle has felt, almost physically, how everything that is best and most precious within him was awakened. Revenge has a different psychology. Its logic is implacable. First, there is a purge of yesterday's adversaries, the partisans of the old regime. Then comes the purge of yesterday's fellow-oppositionists, who now oppose the idea of revenge. Finally, there is a purge of those who defend them. A psychology of vengeance and hatred develops. The mechanics of retaliation become unappeasable. . . ${ }^{47}$

43. It is, of course, impossible fully to depoliticize prosecutions for human rights crimes-or for any crime that attracts a high level of public interest. Part III explores measures that can be taken to minimize the harmful political consequences of prosecutions.

44. Some analysts believe that forgiveness and national reconciliation cannot take place as long as justice is foreclosed. See L. WESCHLER, supra note 11, at 243 (quoting Hannah Arendt's view that "men are unable to forgive what they cannot punish"); $c f$. Neier, Amnesty at the Point of a Gun Isn't Genuine, N.Y. Times, Apr. 10, 1990, at A20, col. 5 (letter to the editor).

45. One of the most important measures taken by Nicaraguan President of Violeta Barrios de Chamorro to bridge divisions between her government and that of the Sandinista party she defeated was to retain as her defense minister Gen. Humberto Ortega Saavedra, who had served in the same capacity under the previous Sandinista government. See Chamorro Takes Nicaragua Helm; Hails a New Era: Retains the Army's Top Sandinista in a Gesture of Reconciliation, N.Y. Times, Apr. 26, 1990, at A1, col. 4.

46. An example of such an amnesty is the Colombian Amnesty Law (No. 35) of November 19, 1982, which did not apply to persons who killed noncombatants and those who otherwise behaved brutally. Sir Francis Bacon drew a distinction between crimes that can be subject to amnesty and those that cannot:

[T]he King may pardon any Offence whatever ... so far as the public is concerned in it, after it is over, and consequently may prevent a popular Action or a Statute, by pardoning the Offence before the suit is commenced; .....

But it seems agreed, that the King can by no previous Licence, Pardon or Dispensation, make an Offence dispunishable which is Malum in se; as being against the Law of Nature, or so far against the Public Good as to be indictable at Common Law, and that a Grant of this kind tending to encourage the doing of Evil, which is the chief End of Government to prevent, is plainly against Reason and the Common Good, and therefore void.

Goldman, supra note 14 , at 3-4 (quoting Bacon).

47. Weschler, A Reporter at Large, THE NEW YORKER, Dec. 10, 1990, at 127. 
Distinguishing "this sort of wholesale vengeance" from prosecutions for crimes, Michnik suggests an answer to Poland's dilemma: "In cases where laws have been broken," the perpetrators "should be indicted and tried, the law should take its course. But we have to remain a nation of laws-that is of crucial importance." $" 48$

\section{THE Duty To Punish Under CuRRENT International LAW}

While analysts agree that governments confronting a legacy of state violence should comply with established rules of international law, they have generally demurred on the question of what, precisely, the law requires. ${ }^{49}$ This tendency toward vagueness can be readily explained: the implications of the most pertinent areas of international law are not immediately obvious. International human rights law traditionally has allowed governments substantial discretion to determine the means they will use to ensure protected rights, ${ }^{50}$ while international penal law has often focused on the power-not duty - of governments to punish violations committed outside their territorial jurisdiction. ${ }^{51}$ When the law has required states to punish offenses committed in their territory, the duty traditionally has applied principally to crimes committed against foreign nationals. ${ }^{52}$

Increasingly, however, international law has required states to punish certain human rights crimes committed in their territorial jurisdiction. Several human rights treaties require States Parties to criminalize particular abuses, such as genocide and torture, investigate violations and seek to punish the wrongdoers. ${ }^{53}$ On their face the more comprehensive treaties, such as the International Covenant on Civil and Political Rights, ${ }^{54}$ are silent about a duty to punish violations of the rights they ensure. But authoritative interpretations of these treaties make clear that a State Party fails in its duty to ensure the cluster of rights protecting physical integrity if it does not investigate violations and seek

48. Id. at 126; cf. A. SOLZHENITSYN, supra note 1, at 177 ("It is unthinkable in the twentieth century to fail to distinguish between what constitutes an abominable atrocity that must be prosecuted and what constitutes that 'past' which 'ought not to be stirred up.'").

49. See supra note 8 .

50. See Tel-Oren v. Libyan Arab Republic, 726 F.2d 774, 777-78 (D.C. Cir. 1984) (per curiam) (Edwards, J., concurring), cert. denied, 470 U.S. 1003 (1985). International human rights undertakings have typically emphasized "obligations of result," leaving to states the determination of means for protecting the rights. See Schachter, The Obligation to Implement the Covenant in Domestic Law, in THE INTERNATIONAL BILL OF RIGHTS 311 (L. Henkin ed. 1981). Increasingly, however, international human rights treaties specify "obligations of means" as well as result. Further, bodies that enforce human rights treaties have often specified means that States Parties must use to fulfill their convention-based obligations of result. See infra text accompanying notes $92-93$.

51. See infra text accompanying notes 63-64.

52. See infra note 65 and accompanying text.

53. See infra Section $\mathrm{B}$.

54. Adopted Dec. 16, 1966, G.A. Res. 2200, 21 U.N. GAOR Supp. (No. 16) at 52, 999 U.N.T.S. 171, reprinted in 6 I.L.M. 368 (1967) [hereinafter "International Covenant"]. 
to punish those who are responsible..$^{55}$ Moreover a state's failure to punish repeated or notorious violations breaches the customary obligation to respect the same set of preeminent rights. ${ }^{56}$

\section{A. International Criminal Law}

\section{General Principles}

Each duty examined below applies to human rights violations that international law defines as criminal. While definitions of "international crimes" vary, ${ }^{57}$ the term in its broadest sense comprises offenses which conventional or customary law either authorizes ${ }^{58}$ or requires states to criminalize, prosecute, and/or punish. Although international law generally establishes rights and duties between and among states, international criminal law imposes obligations on individuals, ${ }^{59}$ making them liable to criminal punishment. ${ }^{60}$ It also impos-

\section{See infra Section C.}

56. See infra Section D.

57. Compare Wright, The Law of the Nuremberg Trial, 41 AM. J. INT'L L. 38, 56 (1947) (a crime against international law is "an act committed with intent to violate a fundamental interest protected by international law or with knowledge that the act will probably violate such an interest, and which may not be adequately punished by the exercise of the normal criminal jurisdiction of any state") with Dinstein, International Criminal Law, 20 ISR. L. REV. 206, 221 (1985) (while international crimes typically are grave offenses that "harm fundamental interests of the whole international community," an offense becomes an international crime only when defined as such by positive international law). Although it is not always clear in writings of international law scholars what consequences are believed to attach to "international crimes," the term is often used to refer to crimes that are subject to universal jurisdiction. See, e.g., Dickinson, Is the Crime of Piracy Obsolete?, 38 HARV. L. REV. 334, 335-38 (1924-25). But see I. BROWNLIE, PRINCIPLES OF PUBLIC INTERNATIONAL LAW 305 (4th ed. 1990) (noting distinction drawn by some publicists between breaches of international law that can be punished by any state, such as violations of the laws of war, and other offenses established by municipal law which international law authorizes any state to punish, such as piracy). The term "international criminal law" is sometimes used more broadly to refer to law pursuant to which "individuals are personally held to account for violations of the international order." Ruy \& Silving, International Criminal Law-A Search for Meaning, in I INTERNATIONAL CRIMINAL LAW 25 (M. Bassiouni \& V. Nanda eds. 1973). The International Law Commission's draft articles on state responsibility use the term "international crimes" to refer to the controversial concept of crimes of a state. Draft Articles on State Responsibility, [1976] 2 Y.B. INT'L L. COMM'N (pt. 2) at 119, U.N. Doc. A/CN.4/SER.A/1976/Add.1; T. MERON, HUMAN RIGHTS AND HUMANITARIAN NORMS AS CUSTOMARY LAW 210 (1989). In recent decades the term has also been used to refer to crimes that would be punishable by an international criminal court if one were established. See infra note 66.

58. In general, international law recognizes a state's right to exercise criminal jurisdiction in situations where it has a significant relationship to the case. Jurisdiction has been recognized, for example, under the "territorial" principle, which applies when the crime occurred in the territory of the prosecuting state; the "passive personality" principle, which applies when the victim is a national of the prosecuting state; the "nationality" principle, which applies when the offender is a national of the prosecuting state; and the principle of "protective" jurisdiction, which recognizes states' right to prosecute crimes that threaten their national security or fundamental governmental functions, regardless of where the crimes were committed. See I. BROWNLIE, supra note 57, at 300-05; Randall, Universal Jurisdiction Under International Law, 66 TEX. L. REV. 785, 786-88 (1988). See generally Harvard Research in Int'l Law, Jurisdiction with Respect to Crime, 29 AM. J. INT'L L. 435 (Supp. 1935). But see S.S. Lotus Case (Fr. v. Turk.), 1927 P.C.I.J. (ser. A) No. 10 (international law, rather than prohibiting exercise of jurisdiction when territorial princjple does not apply, permits exercise of jurisdiction except when specifically prohibited).

59. But see supra note 57 (noting concept of crimes of a state). 
es duties on states with respect to matters usually left to their discretion. ${ }^{61}$ Thus, an amnesty law or an exercise of prosecutorial discretion that is valid under domestic law may nonetheless breach a state's international obligations62

In the eighteenth century, offenses against the law of nations subject to criminal punishment fell into two categories. One comprised a narrow class of offenses, most notably piracy, ${ }^{63}$ that were viewed as a common concern of nations and which states lacking a direct nexus to the crime could nonetheless punish. ${ }^{64}$ The other comprised offenses, such as violations of safe conduct and infringements of the rights of ambassadors, which states were required to punish when committed by one of their citizens against a foreign national. Although different rationales supported international law's concern with these

60. The judgment of the International Military Tribunal at Nuremberg asserted:

[I]nternational law imposes duties and liabilities upon individuals as well as upon States .... [I]ndividuals can be punished for violations of international law. Crimes against international law are committed by men, not by abstract entities, and only by punishing individuals who commit such crimes can the provisions of international law be enforced.

International Military Tribunal, Judgment, reprinted in 41 AM. J. INT'L L. 172, 220-21 (1947) (hereinafter "IMT Judgment"]. As long ago as the eighteenth century it was well established that individuals were liable to punishment for committing offenses against the law of nations. See infra note 65 . But as positivist views of international law gained ascendency in the nineteenth century, international law was widely seen as a set of rules binding states in their mutual relations. Under this view, international law could not directly impose obligations upon individuals; only municipal law could do that. See Schwarzenberger, The Problem of an International Criminal Law, in INTERNATIONAL CRIMINAL LAW 3, 10, 16 (G. Mueller \& E. Wise eds. 1965); see also Manner, The Legal Nature and Punishment of Criminal Acts of Violence Contrary to the Laws of War, 37 AM. J. INT'L L. 407 (1943); cf. Kelsen, Collective and Individual Responsibility in International Law with Particular Regard to the Punishment of War Criminals, 31 CALIF. L. REV. 530, 55356 (1943) (international law specifies some offenses as criminal, though enforcement is undertaken by municipal courts). The concept of crimes against international law, the commission of which gives rise to individual liability, acquired renewed support in the wake of World War II. See Wright, supra note 57, at 56. The development of international human rights law in the second half of the twentieth century has played a significant part in reviving and fortifying the view that individuals can be subjects of international law. See generally T. MERON, HUMAN RIGHTS IN INTERNAL STRIFE: THEIR INTERNATIONAL PROTECTION 33-36 (1987); Janis, Individuals as Subjects of Imternational Law, 17 CORNELL INT'L L.J. 61 (1984); Sohn, The New International Law: Protection of the Rights of Individuals Rather than States, 32 AM. U. L. REV. 1 (1982).

61. In the words of one writer, "When international law defines an act as an offence, the upshot is that the decision whether or not to prosecute offenders is not left to the unfettered discretion of States, which are subjected to international obligations in the matter." Dinstein, supra note 57, at 225.

62. Cf. 1 L. OPPEnHed, INTERNATIONAL LAW 45 (H. Lauterpacht 8th ed. 1955) ("If a State ... possess[es] such rules of Municipal Law as it is prohibited from having by the Law of Nations, it violates an international legal duty."): Vienna Convention on the Law of Treaties, adopted May 23, 1969, art. 27, U.N. Doc. A/C.39/27 (1969), reprinted in 8 I.L.M 679 (1969) [hereinafter "Vienna Convention"); GrecoBulgarian Communities, 1930 P.C.I.J. (ser. B) No. 17, at 23; Polish Nationals in Danzig, 1931 P.C.I.J. (ser. A/B) No. 44, at 24; see also Goldman, supra note 14, at 4; Montealegre, supra note 35 , at 50 .

63. See $4 \mathrm{~W}$. BLACKSTONE, COMMENTARIES *68.

64. A variety of treaties prohibiting slave trade were adopted in the nineteenth and early twentieth centuries. See 1 INTERNATIONAL CRMinal LAw 506-10 (M. Bassiouni \& V. Nanda eds. 1973). Both slavery and slave trade are now generally recognized to be subject to universal jurisdiction. See RESTATEMENT (THIRD), supra note $6, \$ 702$ reporters' note 4 . The crime of brigandage, too, has long been subject to universal jurisdiction. See Cowles, Universality of Jurisdiction Over War Crimes, 33 CALIF. L. REv. 177, 190-94 (1945). 
offenses, ${ }^{65}$ in each instance national courts were the fora in which the law of nations was enforced.

In the wake of World War II, the concept of international crimes expanded to include offenses subject to the jurisdiction of an international tribunal. ${ }^{66}$ More recently, the trend has been toward adoption of conventions that require States Parties to criminalize, prosecute, and/or punish certain offenses when committed in their territorial jurisdiction or under other specified circumstances. ${ }^{67}$ These treaties, like the customary law of the eighteenth century, look to

65. Blackstone offered the following rationale for states' duty to punish offenses against the law of nations:

[W] here the individuals of any state violate [the law of nations], it is then the interest as well as duty of the government under which they live, to animadvert upon them with a becoming severity, that the peace of the world may be maintained. For in vain would nations in their collective capacity observe these universal rules, if private subjects were at liberty to break them at their own discretion, and involve the two states in a war. It is therefore incumbent upon the nation injured ... to demand satisfaction and justice to be done on the offender, by the state to which he belongs .....

4 W. BLACKSTONE, supra note 63 , at *68. Although Blackstone went on to identify three "principle offences against the law of nations," $i d$., the quoted passage appears relevant to only two: "violation of safeconducts," and "infringement of the rights of embassadors." $I d$. These offenses, when committed by a state's citizens, would have violated that state's duty toward the state whose nationals had been directly injured. If the first state fails to punish its offending citizen, Blackstone reasoned, it becomes "an accomplice or abettor of his subject's crime, and draws upon his community the calamities of foreign war." Id. Blackstone offered a different rationale for punishment of piracy, recognizing a right (not duty) of states to punish nonnationals (rather than their own citizens) for reasons of self-defense (rather than to redress an offense against another nation):

As therefore [the piratel has renounced all the benefits of society and government, and has reduced himself afresh to the savage state of nature, by declaring war against all mankind, all mankind must declare war against him: so that every community hath a right, by the rule of selfdefence, to inflict that punishment upon him, which every individual would in a state of nature

have been otherwise entitled to do, for any invasion of his person or personal property.

Id. at *71. But see Burley, The Alien Tort Statute and the Judiciary Act of 1789: A Badge of Honor, 83 AM. J. INT'L L. 461, 482-88 (1989) (in eighteenth century, governments viewed enforcement of law of nations as duty whose discharge was emblematic of civilized nations; while specific and varying interests justified punishment of particular offenses against law of nations, states viewed it as their duty to enforce law of nations as such).

66. See, e.g., Convention on the Prevention and Punishment of the Crime of Genocide, adopted Dec. 9, 1948, art. VI, G.A. Res. 260 A (III), 78 U.N.T.S. 227 (entered into force Jan. 12, 1951) [hereinafter "Genocide Convention"]; International Convention on the Suppression and Punishment of the Crime of Apartheid, art. V, adopted Nov. 30, 1973, G.A. Res. 3068 (XXVII)), 28 U.N. GAOR Supp. (No. 30) at 75, U.N. Doc. A/9030 (1974), reprinted in 13 I.L.M. 50 (1974) (entered into force July 18, 1976) [hereinafter "Apartheid Convention"]. The only instances in which such jurisdiction has been exercised were the prosecutions of major war criminals in Nuremberg by the International Military Tribunal established by the four Allied Powers, and by a similar tribunal, the International Military Tribunal for the Far East, established to try Japanese war criminals in Tokyo. Although efforts to establish a permanent international penal tribunal have been unsuccessful, the prospect of establishing such a court has had a significant impact in shaping the concept of international crimes. See generally 2 B. FERENCZ, AN INTERNATIONAL CRIMINAL COURT 1-61 (1980); Wright, Proposal for an International Criminal Court, 46 AM. J. INT'L L. 60 (1952).

67. See Dinstein, supra note 57, at 216-21. Some of these conventions also include provisions establishing universal jurisdiction, see, e.g., Convention Against Torture and Other Cruel, Inhuman or Degrading Treatment or Punishment, opened for signature Feb. 4, 1985, art. 5(2), reprinted in 23 I.L.M. 1027 (1984), as modified, 24 I.L.M. 535 (1984), 39 U.N. GAOR Supp. (No. 51) at I97, U.N. Doc. A/39/5I (1984) (entered into force June 26, 1987) [hereinafter "Convention Against Torture"], or authorizing international tribunals to exercise criminal jurisdiction, see, e.g., Genocide Convention, supra note 66, art. VI; Apartheid Convention, supra note 66, art. V. For a comprehensive listing of post-war conventions establishing crimes, see Clark, The Influence of the Nuremberg Trial on the Development of International Law, in 
national courts for enforcement. But in contrast to the older law of nations requiring states to provide legal redress for injury to foreign nationals, modern treaties often require states to enforce the rights of their own citizens.

\section{Human Rights Crimes}

\section{a. The Nuremberg Precedent}

Although relatively few violations of human rights are international crimes, international criminal law has played an important-indeed, foundational-role in the development of human rights law. The principle of universality supported the Allied Powers' assertion of jurisdiction over Nazi war criminals for crimes against humanity, ${ }^{68}$ the prosecution of which inaugurated the branch of international law recognizing and protecting human rights. ${ }^{69}$

To the extent that they reached Nazi offenses against German nationals, the Nuremberg prosecutions represented a radical innovation in international law. With few and limited exceptions, international law had not previously addressed a state's treatment of its own citizens, ${ }^{70}$ much less imposed criminal sanctions for such conduct. ${ }^{71}$ The Nuremberg prosecutions thus broadened the scope of international law in general, and of international criminal law in particular.

The Allied Powers and Nuremberg tribunals ${ }^{72}$ justified the innovation on

THE NUREMBERG TRIAL AND INTERNATIONAL LAW 253-54 (G. Ginsburgs \& V. Kudriavtsev eds. 1990).

68. See Demjanjuk v. Petrovsky, 776 F.2d 571, 582 (6th Cir. 1985), cert. denied, 475 U.S. 1016 (1986); Randall, supra note 58, at 789; see also Opening Statement of Prosecution, United States v. Ohlendorf (Case No. 9), IV TRIALS OF WAR CRIMINALS BEFORE THE NUERNBERg MILITARY TRIBUNALS UNDER CONTROL COUNCIL LAW No. 10, at 46-47 (1950) [hereinafter TRIALS OF WAR CRIMINALS].

69. Although the branch of international law concerned with human rights had several pre-war antecedents, it was "born in, and out of the Second World War." Henkin, Introduction, in THE INTERNATIONAL BILL OF RIGHTS 5 (L. Henkin ed. 1981).

70. Antecedents to modern international human rights law are described in $i d$. at 3-5, and in T. FARER, THE GRAND STRATEGY OF THE UNITED STATES IN LATIN AMERICA 63-65 (1988).

71. As noted previously, older principles of international law requiring states to punish delicts of their citizens committed in the states' territorial jurisdiction concerned conduct that violated the rights of other states. See supra note 65 .

72. In all, thirteen cases against war criminals were tried at Nuremberg. The first was prosecuted before the International Military Tribunal (IMT), the judges and prosecutors of which were nationals of the four Allied Powers. Twelve subsequent prosecutions were brought before U.S. Military Tribunals. Additional war criminals were prosecuted before tribunals in German war zones occupied by other Allied nations; before an international tribunal in Tokyo; by the U.S. Army before military courts under the jurisdiction of the theater commander in Germany; by various other countries, including those that had been occupied by German forces during the war; and, eventually, by German national courts.

The IMT trial began on November 14, 1945 and lasted nine and one-half months. Twenty-two leading Nazi figures were prosecuted; all but three were convicted of various crimes within the jurisdiction of the IMT. For comprehensive accounts of the proceedings, see R. CONOT, supra note 32; A. TUSA \& J. TUSA, THE NUREMBERG TRIAL (1984). Proceedings of the International Military Tribunal for the Far East, established in Tokyo to try war criminals from Japan, are described in A. BRACKMAN, THE OTHER NUREMBERG: THE UNTOLD STORY OF THE TOKYO WAR CRIMES TRIALS (1987). For discussion of human rights law generated by the Nuremberg trials, see infra Section E. 
several grounds, ${ }^{73}$ two of which are of interest here. ${ }^{74}$ First, crimes against humanity could be punished by an international court because the conduct, by its nature, offended humanity itself. ${ }^{75}$ Because the crime originated in "humanity"- - presumably under natural law ${ }^{76}$-its legal status and consequences transcended the province of municipal law. ${ }^{77}$ A person who committed crimes

73. The following discussion addresses the Nuremberg tribunals' punishment of crimes against humanity, and does not consider justifications for their assertion of jurisdiction over other crimes. But see infra note 79.

74. The Allied nations' chief response to charges that they were applying ex post facto law was that international law already recognized the human rights crimes for which Nazi war criminals were prosecuted since those crimes violated principles common to the major legal systems of the world. See Jackson Report, supra note 32, at 184, 186; United States v. von Leeb (Case No. 12), XI TRIALS OF WAR CRIMINALS, supra note 68, at 510; R. WOETZEL, THE NUREMBERG TRIALS IN INTERNATIONAL LAW 183 (1962); Clark, Crimes Against Humanity, in THE NUREMBERG TRIAL AND INTERNATIONAL LAW 193-94 (G. Ginsburgs \& V. Kudriavtsev eds. 1990). Proponents of the prosecutions also asserted that the extremely atrocious nature of the crimes put the defendants on notice that their conduct offended the law of nations. See Wright, supra note 57 , at 61 . Further, the prosecuting nations noted that murder was proscribed by German law, and that the acts constituting crimes against humanity generally involved deliberate murders. See The Legal Basis of the Nuremberg Trial, United States Department of State, Office of International Information (1945), at XVIIA (also suggesting that, as sovereign power in Germany following unconditional surrender of German government, Allies were entitled to enact retroactive laws).

75. This view was implicit in the tribunals' answer to charges that they were imposing "victors' justice." The U.S. Military Tribunal asserted in the Einsatzgruppen Case:

The defendants are in court not as members of a defeated nation but because they are charged with crime. They are being tried because they are accused of having offended against society

itself, and society, as represented by international law, has summoned them for explanation.

United States v. Ohlendorf (Case No. 9), IV TRIALS OF WAR CRIMINALS, supra note 68, at 462. Similarly, the tribunal asserted: "Humanity is the sovereignty which has been offended and a tribunal is convoked to determine why." Id. at 497; see also Opening Speech of Justice Robert H. Jackson, Chief Prosecutor for the United States, Nov. 21, 1945, II TRIAL OF THE MAJOR WAR CRIMINALS BEFORE THE INTERNATIONAL MILTARY TRIBUNAL 155 (1947) [hereinafter TRIAL OF MAJOR WAR CRIMINALS] (asserting to IMT, "The real complaining party at your bar is Civilization.").

76. See The Legal Basis of the Nuremberg Trial, supra note 74, at XVIII (actions of defendants before IMT "are certainly at least 'natural crimes' because they constitute inhuman acts"); see also Final Speech of Sir Hartley Shawcross, Chief Prosecutor for Great Britain, July 27, 1946, XIX TRIAL OF MAJOR WAR CRIMINALS, supra note 75, at 472; United States v. von Leeb (Case No. 12), XI TRIALS OF WAR CRMINALS, supra note 68 , at 476 (both quoting or citing passage from Grotius, infra note 77).

77. More than three centuries before the Nuremberg trials, the eminent Dutch jurist Hugo Grotius framed a natural law justification for foreign intervention that would support the prosecutions:

The fact must also be recognized that kings, and those who possess rights equal to those kings,

have the right of demanding punishments not only on account of injuries committed against

themselves or their subjects, but also on account of injuries which do not directly affect them but

excessively violate the law of nature or of nations in regard to any persons whatsoever. 2 H. GRotius, DE JURE BELl ET PACIS ch. XX, \$ XL, para. 1 (1625) (Carnegie trans. 1925). The British jurist Richard Zouche similarly held that "when crimes are very atrocious and very plain," kings "have the right to demand satisfaction not only for wrongs done to themselves or their subjects, but also for wrongs to any person whomsoever, which are in flagrant violation of the law of nature and nations; since the power of punishing is not merely derived from civil law, but comes from natural law also." 2 R. ZOUCHE, IURIS ET IUDICI FECIALIS, SIVE, IURIS INTER GENTES, ET QUAESTIONUM DE EODEM EXPLICATIO 116 (1650), reprinted in THE CLASSICS OF INTERNATIONAL LAW (1911). The Swiss publicist Emerich de Vattel, too, found justification for an exception to the general rule that states could punish only crimes against themselves if the offense were so heinous that it offended all mankind. E. DE VATTEL, 1 LE DROIT DES GENS, ch. XIX, paras. 232-33 (1758). 
against humanity was, like the pirate, hostis humani generis ${ }^{78}$ —"an enemy of all mankind"-over whom any state could assert criminal jurisdiction.

It was a short step from recognition of crimes against humanity as a violation of international law to the assertion that such crimes could be punished by an international court. ${ }^{79}$ The U.S. Military Tribunal in the Einsatzgruppen Case reasoned:

Where law exists a court will rise . . . . It would be an admission of incapacity, in contradiction of every self-evident reality, that mankind ... should be unable to maintain a tribunal holding inviolable the law of humanity, and, by doing so, preserve the human race itself. ${ }^{80}$

78. 4 W. BLACKSTONE, supra note 63 , at *68 (quoting Sir Edward Coke); see also H. WHEATON, ELEMENTS OF INTERNATIONAL LAW 162 (1866). The analogy of human rights criminals to pirates should not be overdrawn; many of the justifications for establishing universal jurisdiction over piracy are absent in the case of human rights violations. Those rationales include the fact that pirates' victims were genuinely international, see Cowles, supra note 64 , at $185-87$, lending many states a legitimate interest in prosecuting pirates; the notion (often factually incorrect) that pirates were stateless, see 1 L. OPPENHEM, supra note 62 , at 609 , thereby giving every state the right to assert jurisdiction; and the fact that piracy could disrupt international commerce, see B. DUBNER, THE LAW OF INTERNATIONAL SEA PIRACY 62 (1980), giving states generally a direct interest in deterring the crime through prosecution. In contrast, human rights crimes are, with some exceptions, committed by state of ficials or agents against their own citizens in their own territory, producing no direct injury to other states or their nationals. Accordingly, if universal jurisdiction was well established in international law by 1945 , its extension to human rights offenses nonetheless represented a significant inroad into traditional notions of international law, which placed overwhelming emphasis on state sovereignty. One rationale for universal jurisdiction that is equally applicable to pirates and human rights violators is that both offenders commit acts so antithetical to common standards of civilization that they have, in effect, renounced the right to be protected by its laws. $C f .2$ A. GENTILI, DE IURE BELLI LIBRI TRES 22 (1612) (J. Rolfe trans. 1932) ("malefactors do not enjoy the privileges of a law to which they are foes"); 4 W. BLACKSTONE, supra note 63 , at $* 71$ (a pirate can be punished because "he has renounced all the benefits of society and government"). Moreover, in both instances international cooperation may be necessary to ensure apprehension. See Dickinson, supra note 57, at 338.

79. The IMT in fact had a hybrid character, reflecting diverse justifications cited for its assertion of jurisdiction. Jurisdiction was based in part upon the long-established right of belligerents to prosecute their enemies for violations of the laws of war committed during hostilities. See Wright, supra note 57, at 45, 49. Even this basis of jurisdiction was controverted, see Schick, The Nuremberg Trial and the International Law of the Future, 41 AM. J. INT'L L. 770, 778-80 (1947), and the jurisdiction of the IMT in any event covered conduct that could not even arguably be prosecuted on this basis. Jurisdiction was also based on the prosecuting nations' status as occupying powers. See IMT Judgment, supra note 60, at 216 (the "making of the Charter was the exercise of the sovereign legislative power by the countries to which the German Reich unconditionally surrendered; and the undoubted right of these countries to Iegislate for the occupied territories has been recognized by the civilized world."); see also Finch, The Nuremberg Trial and International Law, 41 AM. J. INT'L L. 20, 22 (1947); Schwelb, Crimes Against Humanity, 23 BRIT. Y.B. INT'L L. 178, 210 (1946); Wright, supra note 57, at 51. The IMT also purported to operate as an international court applying the law of nations. See IMT Judgment, supra note 60 , at 216 (the "Charter is not an arbitrary exercise of power on the part of the victorious Nations, but in the view of the Tribunal, ... it is the expression of international law existing at the time of its creation; and to that extent is itself a contribution to international law."); see also R. WOETZEL, supra note 74, at 55-57. The IMT's status as an international tribunal was reinforced by the fact that the Nuremberg Charter, though executed by the United States, Great Britain, France and the Soviet Union, was ratified by nineteen other nations. The defendants were tried for crimes against international law, as codified in the Nuremberg Charter, without reference to German law. See id. at 35-36. Indeed, the Charter explicitly provided that the IMT would have jurisdiction over crimes against humanity "whether or not in violation of the domestic law of the country where perpetrated." See infra text accompanying note 220.

80. United States v. Ohlendorf, IV TRIALS OF WAR CRIMINALS, supra note 68, at 499-500; $c f$. United States v. von Leeb, XI TRIALS OF WAR CRIMINALS, supra note 68 , at 480 (since there is "no doubt of the 
Indeed, the notion that international judicial enforcement was the only means of genuinely establishing the rule of international law was a central premise of the Allied Powers' program of prosecution. ${ }^{81}$

Second, the Allied Powers sought to justify the novelty of judging matters traditionally subject to the exclusive sovereign power of states by linking crimes against humanity to conduct that had unambiguous international ramifications-international war. Crimes against humanity, the Allies asserted, are a menace to world peace; World War II supplied ample justification for their claim. ${ }^{82}$ The Allied nations hewed closely to this rationale in establishing the jurisdiction of the International Military Tribunal ("IMT") over crimes against humanity. These could be prosecuted only when committed "in execution of or in connection with" one of the other two crimes subject to IMT jurisdiction: crimes against peace and war crimes. ${ }^{83}$

\section{b. Post-Nuremberg Developments}

In the wake of World War II, it may have seemed plausible to maintain that the international community had an interest in suppressing crimes against humanity because they threatened world peace. But in subsequent years, states were more inclined to avoid pressing human rights concerns with other governments, in large part because they feared that such actions would actually exacerbate international tensions. ${ }^{84}$

criminality of the acts with which the defendants are charged," the fact that no court had previously been established to try such violations is no bar to tribunal's assertion of jurisdiction).

81. See Kahn, From Nuremberg to the Hague: The United States Position in Nicaragua v. United States and the Development of International Law, 12 YALE J. INT'L L. 1, 11 (1987) (for parties and IMT, "adjudication was to be the process by which 'enforcement' of international law occurred"). Telford Taylor, who assisted in the prosecution of major war criminals before the IMT and led the subsequent prosecutions before U.S. Military Tribunals in Nuremberg, made the point this way: "No principle deserves to be called such unless men are willing to stake their consciences on its enforcement. That is the way law comes into being, and that is what was done at Nuernberg." TAYLOR REPORT, supra note 32, at 112 .

82. Statements by prosecutors representing the Allied Powers and the decisions of the tribunals make constant reference to this theme. Telford Taylor stated the view succinctly in his final report on the U.S. prosecutions in Nuremberg: "The Second World War abundantly proved that dictatorship is the most constant and serious menace to world peace, as well as to the preservation of liberty and the maintenance of moral standards." TAYLOR REPORT, supra note 32, at 104; see also United States v. Altstoetter (Case No. 3), III TRIALS OF WAR CRIMINALS, supra note 68 , at 982.

83. Charter of the International Military Tribunal, art. 6(c), 59 Stat. 1546, 1547 (1945), E.A.S. No. 472 , 82 U.N.T.S. 284 [hereinafter Nuremberg Charter]. For further discussion of this subject, see infra text accompanying notes 229-37.

84. It took little time for this concern to prevail over international efforts to promote human rights. During its early years, as tensions between the U.S.S.R. and the United States mounted, the Commission on Human Rights of the United Nations faced substantial opposition, from both Eastern-bloc and Western nations, to its efforts to draft human rights conventions and to implement human rights guarantees. While the Commission was able to draft the nonbinding Universal Declaration of Human Rights, G.A. Res. 217, U.N. Doc. A/810, at 71 (1948), in short order, it did not finish drafting the International Covenant on Civil and Political Rights, supra note 54, and the International Covenant on Economic, Social and Cultural Rights, adopted Dec. 16, 1966, G.A. Res. 2200A, 21 U.N. GAOR Supp. (No. 16) at 49, U.N. Doc. A/6316 (1966) (entered into force Jan. 3, 1976), both of which would be binding on States Parties, until the mid-1950s; the covenants were not adopted by the General Assembly until 1966, and they did not enter into force until 
This reticence accounts for the failure of efforts, inspired by the Nuremberg prosecutions and contemplated in the Genocide Convention, ${ }^{85}$ to create a permanent international criminal court. ${ }^{86}$ Describing opposition to the creation of such a tribunal by state representatives who helped draft the Genocide Convention, one writer observed:

[S]ince the Convention envisaged that members of governments might be authors of the crime [of genocide], there was the danger that the attempt to punish offenders through an international tribunal might jeopardize peace. ${ }^{87}$

In effect, then, one of the asserted justifications for the Nuremberg prosecutions - the claim that the international community should prosecute crimes against humanity because they threaten world peace-was turned on its head in the post-war years. ${ }^{88}$ With this development, the vision nurtured by the Nuremberg precedent-that of a system of international criminal law whose authority depended upon its enforcement by a permanent international court-evanesced. ${ }^{89}$

1976.

85. Supra note 66

86. The idea of establishing an international criminal court had been discussed for some decades before the Nuremberg prosecutions, see Manner, supra note 60, at 428-32, and in 1937 the League of Nations adopted a Convention for the Creation of an International Criminal Court. Although several states signed the Convention, none ratified it, and the treaty never entered into force. See 1 B. FERENCZ, supra note 66, at 54. Efforts to establish an international criminal court gained substantial momentum only after the Nuremberg prosecution. In its wake, there was some enthusiasm within the United States Department of State for establishing a permanent international court, but in a few short years that support dissipated. Interview with Telford Taylor in New York City (June 21, 1990). See also 2 B. FERENCZ, supra note 66, at 4-5. Subsequent efforts encountered especially strong antipathy during periods of pronounced international tension. See generally id. A proposal to create an International Court of Human Rights, presented to the working group that drafted the International Covenant on Civil and Political Rights, also was rejected. See Pechota, The Development of the Covenant on Civil and Political Rights, in THE INTERNATIONAL BILL OF RIGHTS 49 (L. Henkin ed. 1981).

87. L. KUPER, GENOCIDE 37 (1982); cf. 2 B. FERENCZ, supra note 66, at 46 (establishment of a permanent international criminal court was opposed on the basis that its existence "might even impair the possibilities of peace by interfering with the process of political conciliation").

88. This development was virtually inevitable; the prospect of states asserting a right even to criticize other nations' treatment of their own citizens-let alone to prosecute such conduct-would be anathema to governments long accustomed to nearly absolute sovereign prerogative in such matters. The fact that the only precedent for such prosecutions had been tied so directly to conquest in war could only reinforce states' inclination to associate international prosecutions with hostile inter-state relations. In this regard it is noteworthy that the only significant prospect of international prosecutions since the Nuremberg trials has also arisen in the wake of the prospective defendants' resounding defeat in war-this time, the Persian Gulf war of January-March 1991.

89. States have also been reluctant to file inter-state complaints pursuant to human rights conventions that establish such a procedure. As of May 30, 1991, the European Commission of Human Rights had received, since 1953, only 11 inter-state complaints (submitted by 21 applicant states) alleging violations of the European Convention, supra note 34. In the same period, it had received some 18,300 applications from individuals, of which approximately 2,000 were still pending on May 30, 1991. To date, no state has filed an inter-state complaint pursuant to Article 41 of the International Covenant, supra note 54. See de Zayas, The Potential for the United States Joining the Covenamt Family, 20 GA. J. INT'L \& COMP. LAW 299,302 (1990). 
In contrast, the other justification for the Allies' prosecution of crimes against humanity - the principle that every human being enjoys fundamental rights independent of domestic law - gained broad acceptance in subsequent decades. This principle has been affirmed in numerous international instruments, and widespread adherence to human rights conventions has reinforced the claim that human rights violations are a legitimate concern of all nations. ${ }^{90}$ As human rights guarantees have acquired the status of positive international law, the legal fictions invoked by the Allied Powers to justify the Nuremberg prosecutions have diminished in importance-while, ironically, states' willingness to prosecute human rights violations committed outside their territory has dissipated. ${ }^{11}$

\section{c. Domestic Enforcement}

While issues of jurisdictional power dominated early developments in human rights law, more recent developments have emphasized domestic enforcement of international obligations. For example, human rights treaties drafted in recent years have often specified domestic means of enforcing rights recognized in earlier conventions, including criminal prosecution of violators. ${ }^{92}$

90. Virtually every nation has adhered to at least one international human rights agreement, Henkin, supra note 69 , at 1 , and human rights is now a prominent subject of international diplomacy. See The Text of the Political Declaration, N.Y. Times, July 11, 1990, at A4, col. 4; The Group of 7 Statement: Concern From East Europe to China, N.Y. Times, July 16, 1989, at 17, col. 1.

91. But see supra note 88 (noting possibility of international prosecutions for war crimes committed during recent Persian Gulf war). States have, in general, been more willing to assert universal jurisdiction to punish World War II criminals than to prosecute current offenders. A number of countries, including Israel and Australia, have enacted laws vesting domestic courts with jurisdiction over Nazi war crimes. See Study as regards ensuring the arrest, extradition and punishment of persons responsible for war crimes and crimes against humanity and the exchange of documentation relating thereto: Report of the U.N. Commission on Human Rights, U.N. Doc. E/CN.4/983, at 10, paras. 25,29 (1969) [hereinafter UN. Study on Punishment of War Criminals]. An Israeli court cited universal jurisdiction as one basis of its jurisdiction over Adolf Eichmann, who was prosecuted in Israel in 1961 for Nazi war crimes, including crimes against humanity and crimes against the Jewish people. Attorney Gen. of Isr. v. Eichmann, 36 I.L.R. 18, 26 (Isr. Dist. Ct.-Jerusalem 1961, aff'd, 36 I.L.R. 277 (Isr. Sup. Ct. 1962). The Sixth Circuit cited the principle of universal jurisdiction to justify extraditing another war criminal, John Ivan Demjanjuk, to Israel to face charges of crimes against humanity and crimes against the Jewish people. Demjanjuk v. Petrovsky, 776 F.2d 571, 582-83 (6th Cir. 1985), cert. denied, 475 U.S. 1016 (1986). The Israeli District Court in Jerusalem convicted Demjanjuk and sentenced him to death in 1988. A French court apparently invoked the principle of universality in rejecting a challenge to the legality of Nazi war criminal Klaus Barbie's arrest by French authorities in Guiana. The French Chambre d'accusation (of the Court of Appeal) found that the crimes against humanity with which Barbie was charged "do not simply fall within the scope of French municipal law but are subject to an international criminal order to which the notions of frontiers and extradition rules arising therefrom are completely foreign." Excerpted in Barbie, 78 I.L.R. 125, 130 (1988). This finding was affirmed by the Court of Cassation (Criminal Chamber) on October 6, 1983. See id. at 128-31. On July 4, 1987 Barbie was convicted by the Cour d'Assises du Rhone of 340 counts of 17 crimes against humanity, and was sentenced to life imprisonment. 78 I.L.R. 148 (1988) (editor's note).

92. The Convention Against Torture, supra note 67, adopted by the United Nations General Assembly in 1984, specifies a series of legal measures that States Parties must adopt to ensure suppression of torture-a practice already proscribed in the 1948 Universal Declaration of Human Rights, supra note 84, and in the International Covenant on Civil and Political Rights, supra note 54, which was adopted by the U.N. General Assembly in 1966. See J. BURGERS \& H. DANELIUS, THE UNITED NATIONS CONVENTION AGAINST 
Notably, bodies that monitor compliance with several human rights treaties that are textually silent about punishment have made clear that investigation and prosecution play a necessary part in States Parties' fulfillment of certain duties under the conventions. ${ }^{93}$

Although surprising in light of the treaties' failure to mention punishment, these interpretations are a natural outgrowth of broad trends in international law, as are recent conventions explicitly requiring punishment of human rights crimes. International law has long relied upon criminal sanctions to secure compliance with norms deemed essential to international order. ${ }^{94}$ When, more recently, international law established human rights guarantees, ${ }^{95}$ it was therefore natural that criminal law would play a role in securing rights that are of paramount importance. And with the collapse of states' resolve to establish a permanent international criminal court, it was also inevitable that human rights law would revert to the older paradigm of international penal law, which envisaged that domestic courts would enforce criminal prohibitions. ${ }^{96}$ Further, since human rights can be fully assured only when there are adequate safeguards in domestic law, it is scarcely surprising that states' duty to secure fundamental rights has been found to require an appropriate response by national courts when violations occur.

While modern law favors enforcement by courts of the state in which violations occur, that preference can be overridden if necessary to achieve the paramount aim of human rights criminal law: to prevent atrocious crimes by

TORTURE 1 (1988); G.A. Res. 39/46 (1984), preambular para. 5 (General Assembly, adopting Convention Against Torture, expresses its desire to achieve "a more effective implementation of the existing prohibition under international and national law of the practice of torture..."). Similarly, the Inter-American Convention to Prevent and Punish Torture, adopted Dec. 9, 1985, OEA/ser.A./42 (1986), 67 O.A.S.T.S., reprinted in 25 I.L.M. 519 (1986) (entered into force 1987), which was adopted by the General Assembly of the Organization of American States (O.A.S.) in 1985, sets forth measures that States Parties must adopt to eradicate torture-a practice prohibited by the American Convention on Human Rights, adopted Jan. 7, 1970, O.A.S. Official Records, OEA/ser.K./XVI/1.1, doc. 65 rev. 1, corr. 1 (1970), reprinted in 9 I.L.M. 673 (1970) [hereinafter "American Convention"]. Although obligatory for States Parties, the duties specified in these treaties are not the exclusive means states can use to enforce rights established by other sources of international law.

93. This trend, which is examined in Section C, may be partly attributable to the fact that international organizations, having drafted and promulgated major human rights treaties some decades ago, are now increasingly concerned with monitoring implementation of the conventions. A more particular explanation may have to do with the nature of human rights violations committed by many governments in recent decades. Torture and extra-legal executions are often committed in secrecy, and a lack of government accountability is an essential element of forced "disappearances." See Orentlicher, Bearing Witness: The Art and Science of Human Rights Fact-Finding, 3 HARV. HUM. RTS. J. 83, 94 (1990). As bodies that monitor compliance with human rights treaties began to examine these violations, it became increasingly important to identify states' affirmative duties to ensure fundamental rights, since direct state responsibility for violations often could not be established conclusively.

94. See supra notes 64-65 and accompanying text.

95. See supra text accompanying notes 69,90 .

96. See supra text accompanying note 65 . More generally, for purposes of establishing state responsibility under international law, courts have long been regarded as organs of the state. See C. EAGLETON, THE RESPONSIBILITY OF STATES IN INTERNATIONAL LAW 68-69 (1928); Kelsen, supra note 60, at 538. Consistent with this approach, the performance of national courts in securing protected rights is one measure of a state's compliance with its international human rights obligations. 
ensuring that offenders are punished. This scheme-a preference for domestic enforcement with allowance for "fallback" international jurisdiction-is embodied in several recent and draft conventions, which place primary responsibility for punishing proscribed conduct on the state where the crime occurred, but establish universal jurisdiction to ensure prosecution in the event that the government most responsible for suppressing violations fails to bring offenders to account. ${ }^{97}$

\section{B. Human Rights Conventions Specifying a Duty To Prosecute}

The most explicit obligations to punish human rights crimes that are likely to be relevant to societies emerging from dictatorship are established by the Convention on the Prevention and Punishment of the Crime of Genocide ${ }^{98}$ ("Genocide Convention") and the Convention Against Torture, and Other Cruel, Inhuman or Degrading Treatment or Punishment ${ }^{99}$ ("Convention Against Torture"). ${ }^{100}$ Although both require States Parties to prosecute the conduct they proscribe, the two conventions embody profoundly different visions of interna-

97. See infra text accompanying notes $123-25$; see also Clark, supra note 67 , at 256.

98. See supra note 66 . As of June $6,1991,101$ countries had ratified the convention.

99. See supra note 67 . As of June $6,1991,55$ countries had ratified the convention.

100. Various other human rights treaties require States Parties to criminalize particular acts, e.g., International Convention on the Elimination of All Forms of Racial Discrimination, adopted Dec. 21, 1965, art. 4, G.A. Res. $2106 \mathrm{~A}(\mathrm{XX})$ (entered into force Jan. 4, 1969); Apartheid Convention, supra note 66, art. $\mathrm{V}$, or to punish violations of a particular right, e.g., Supplementary Convention on the Abolition of Slavery, the Slave Trade, and Institutions and Practices Similar to Slavery, adopted Sept. 7, 1956, 3 U.S.T. 3201, T.I.A.S. No. 6418, 266 U.N.T.S. 40, 42-43. The four Geneva Conventions of 1949 also require States Parties to prosecute certain violations. Each of these conventions, which set forth standards of conduct relating to armed conflict, identifies several prohibitions the violation of which is deemed a "grave breach" of the convention. These include such acts as "wilful killing, torture or inhuman treatment, including biological experiments, wilfully causing great suffering or serious injury to body or health, unlawful deportation or transfer or unlawful confinement . ..." Geneva Convention Relative to the Protection of Civilian Persons in Time of War, adopted Aug. 12, 1949, art. 147, 6 U.S.T. 3516, T.I.A.S. No. 3365, 75 U.N.T.S. 287; see also Geneva Convention for the Amelioration of the Condition of the Wounded and Sick in Armed Forces in the Field, adopted Aug. 12, 1949, art. 50, 6 U.S.T. 3114, T.I.A.S. No. 3362, 75 U.N.T.S. 31; Geneva Convention for the Amelioration of the Condition of Wounded, Sick and Shipwrecked Members of Armed Forces at Sea, adopted Aug. 12, 1949, art. 51, 6 U.S.T. 3217, T.I.A.S. No. 3363, 75 U.N.T.S. 85; Geneva Convention Relative to the Treatment of Prisoners of War, adopted Aug. 12, 1949, art. 130, 6 U.S.T. 3316, T.I.A.S. No. 3364, 75 U.N.T.S. 135. The conventions require High Contracting Parties to "enact any legislation necessary to provide effective penal sanctions for persons committing, or ordering to be committed, any of the grave breaches" to the conventions, Geneva Conventions of 1949, arts. 146/49/50/129, and further provide:

Each High Contracting Party shall be under the obligation to search for persons alleged to have committed, or to have ordered to be committed, such grave breaches, and shall bring such persons, regardless of their nationality, before its own courts. It may also, if it prefers, ... hand such persons over for trial to another High Contracting Party concerned, provided such High Contracting Party has made out a prima facie case.

Id. Although Article 3 common to all four conventions proscribes such conduct as torture and summary execution in the context of non-international armed conflict, it is generally thought that the "grave breaches" provisions apply only to acts committed during international armed conflicts. See, e.g., T. MERON, supra note 57, at 33 n.93. Because this Article is concerned with the duty of successor governments vis-a-vis abuses committed against their own citizens, the duty to punish under the Geneva Conventions is not analyzed here. 
tional human rights law. Drafted in the wake of World War II, the Genocide Convention reflects a paradigm, inspired by the Nuremberg prosecutions, of a world order in which internationally recognized rights are enforced by an international tribunal. Establishment of a world court was a key objective of the convention's chief proponents, but their efforts were built on an edifice that was crumbling even as their labor progressed. By the time the drafters' work was completed, support for an international penal tribunal had so dissipated ${ }^{101}$ that the convention's provision for jurisdiction by such a court was little more than an acknowledgment of a faded vision, and chief responsibility for prosecuting genocide fell to the state most responsible for the crimes. ${ }^{102}$ Thus the Genocide Convention at once embodies a vanishing commitment to a system of international enforcement and an early manifestation of the more modern emphasis on domestic enforcement. ${ }^{103}$

The Convention Against Torture, which the General Assembly adopted thirty-six years after it adopted the Genocide Convention, reflects a pragmatic acceptance of the limited role of international enforcement in securing protected rights. No mention is made of an international tribunal. And while the Convention establishes a form of universal jurisdiction over torturers, chief responsibility for punishing violations lies with the state in which the crime occurred.

\section{The Genocide Convention}

The principle purpose of the Convention on the Prevention and Punishment of the Crime of Genocide was, as its name suggests, to prevent genocide ${ }^{104}$ by ensuring punishment of the crime. ${ }^{105}$ Virtually the entire convention is

101. See supra text accompanying notes 84-89.

102. See infra text accompanying notes 106-07.

103. See supra text accompanying notes 92-96.

104. Article II of the Genocide Convention, supra note 66, defines genocide as one of the following acts when committed "with intent to destroy, in whole or in part, a national, ethnical, racial or religious group, as such":

(a) Killing members of the group;

(b) Causing serious bodily or mental harm to members of the group;

(c) Deliberately inflicting on the group conditions of life calculated to bring about its physical

destruction in whole or in part;

(d) Imposing measures intended to prevent births within the group;

(e) Forcibly transferring children of the group to another group.

105. See U.N. Doc. E/AC.25/3 at 8 (1948) (remarks of United Nations Secretary General); U.N. GAOR, 178 th, 179th plen. mtg., at 832 (1948) (remarks of delegate from Netherlands). While the travaux preparatoires suggest that one impetus behind the Convention was a desire to condemn World War II atrocities, see, e.g., id. at 825 (remarks of delegate from France), the drafting records indicate that the overriding purpose was to prevent a recurrence by assuring punishment of offenders. See, e.g., id. at 811 (remarks of Soviet delegate); id. at 819 (remarks of delegate from Pakistan); id. at 820 (remarks of U.S. delegate); id. at 823 (remarks of Australian delegate); $i d$. at 840 (remarks of Polish delegate). Another impetus was a desire to correct what many viewed as a serious shortcoming of the Nuremberg prosecutions: the IMT's determination that it could convict Nazis of crimes against humanity only when the offenses were committed "in execution of or in connection with" crimes against peace or war crimes. See Office of United States Chief of Counsel for Prosecution of Axis Criminality, Nazi Conspiracy and Aggression (Opinion and Judgment of the International Military Tribunal) 84 (1947), quoted in Genocide: A Commentary on the 
designed to serve this purpose. Pursuant to Article I, Contracting Parties "confirm that genocide ... is a crime under international law which they undertake to prevent and to punish," and Article III sets forth various forms of participation in genocide that "shall be punishable." Article IV provides that persons "committing genocide or any of the other acts enumerated in article III shall be punished, whether they are constitutionally responsible rulers, public officials or private individuals," while Article V requires Contracting Parties to enact legislation necessary to give effect to the Convention "and, in particular, to provide effective penalties for persons guilty of genocide." Article VI specifies the tribunals that should try cases of genocide:

Persons charged with genocide or any of the other acts enumerated in article III shall be tried by a competent tribunal of the State in the territory of which the act was committed, or by such international penal tribunal as may have jurisdiction with respect to those Contracting Parties which shall have accepted its jurisdiction.

Since the "international penal tribunal" contemplated by the Convention was never created, the duty established by Article VI devolves upon the state in which the crimes occurred.

What has widely been viewed as a major flaw in the Genocide Convention-its reliance on domestic courts for punishment ${ }^{106}$-leaves unambiguous

Convention, 58 YALE L.J. 1142, 1143 (1949); U.N. GAOR, 178th, 179th plen. mtg., at 820 (1948) (comments of U.S. delegate); $i d$. at 822-23 (remarks of delegate from Australia). This limitation had precluded prosecution of abominations against Germany's Jewish population before 1939, see infra note 230 and accompanying text; the definition of genocide contained in the Genocide Convention imposes no requirement of a nexus to war.

106. In the view of the U.S. delegate, "If the punishment of [genocide] was left to the State in question, the convention on genocide would be in the nature of a fraud." U.N. GAOR, 178th, 179th plen. mtg., at 821 (1948). Other delegates voiced similar doubts about the willingness of national courts to prosecute genocide. See, e.g., id. at 823 (remarks of delegate from Australia); id. at 829 (remarks of delegate from Egypt); see also L. KUPER, supra note 87, at 37-38; Genocide: A Commentary on the Convention, supra note 105 , at 1147. But a "storm of protest" was directed against a draft provision that would have required Contracting Parties to submit persons guilty of genocide for trial before an international court if 1 ) the states were unwilling to try or extradite the offenders, or 2) the offenders were acting with the support or on behalf of the state. L. KUPER, supra note 87, at 36-37. Opponents charged that an international court would infringe national sovereignty, see U.N. GAOR, 178th, 179 th plen. mtg., at 815 (1948) (remarks of Soviet representative); id. at 842 (remarks of delegate from Poland), and, as noted earlier, expressed concern that international prosecution of offenders could jeopardize world peace. See text accompanying note 87 , supra. While delegates to the drafting committee doubted states' willingness to prosecute acts of genocide committed in their territory, there was no question of Contracting Parties' duty to do so. Indeed, a proposal to include a provision contemplating reparations for genocide was defeated because some delegates feared that the draft provision would dilute the Convention's emphasis on criminal punishment. The provision had been included in the original draft convention prepared by the Secretary General. Draft Convention on the Crime of Genocide, art. XIII, U.N. Doc. E/447 (1947). Delegates who had opposed earlier proposals relating to an international penal tribunal were willing to accept the final text in part because efforts to include in the definition of genocide acts directed against "political groups" had been defeated. With this, the risk that states would be brought to account for persecuting political opponents had significantly diminished. See L. KUPER, supra note 87, at 38. Proposals to establish universal jurisdiction were also defeated. Again, opponents claimed that allowing courts to punish officials of another state would infringe national sovereignty and could provoke international tension. See N. ROBINSON, THE GENOCIDE CONVENTION 31-32 (1960). 
Contracting Parties' duty to punish persons who commit genocide in the states' territory. ${ }^{107}$ In practice, however, few post-transition situations would be covered by the Convention. Systematic repression is often directed against perceived or actual political opponents. But acts directed against "political groups" were excluded from the Convention's definition of genocide. ${ }^{108}$ Also, even the most depraved violations would lie beyond the scope of the Convention unless "committed with intent to destroy, in whole or in part," one of the specified groups "as such." 109

The jurisdiction established by the Genocide Convention is not exclusive. Scholars and judicial bodies concur that customary law establishes universal jurisdiction over genocide. ${ }^{110}$ Moreover there is substantial support for the view that customary law requires states to prosecute acts of genocide committed in their territory. The International Court of Justice has asserted, in an advisory opinion, that the principles underlying the Genocide Convention "are recognized by civilized nations as binding on States, even without any conventional obligation." All Although the opinion does not specify which provisions reflect customary norms, those requiring punishment pursuant to the territorial principle, ${ }^{112}$ which are the heart of the Convention, surely are included. ${ }^{113}$ The

107. The duty probably would not arise under the Convention unless a state became a party before the acts constituting genocide took place. See Vienna Convention, supra note 62, art. 28 (establishing general rule that treaty provisions do not apply to acts that took place before entry into force of treaty for relevant party). An amnesty foreclosing prosecution of persons who committed genocide would, however, violate a state's obligations under customary law. See infra text accompanying notes 111-15.

108. See supra note 106. Proposals to include "political groups" in the definition were rejected in large part because delegates feared that their governments would face interference in their internal affairs if genocide were defined to include acts committed to destroy political groups. See L. KUPER, supra note 87, at 29. Kuper adds: "I think. . . that one may fairly say that the delegates, after all, represented governments in power, and that many of these governments wished to retain an unrestricted freedom to suppress political opposition." Id. at 30.

109. Genocide Convention, supra note 66, art. II. For example, the majority of persons killed by the Khmer Rouge, whose savage policies caused the deaths of over a million Cambodians in the 1970's, may not have been victims of genocide because it is not clear that the Khmer Rouge intended to kill members of a national group "as such." See generally B. Kiernan, The Cambodian Genocide: Issues and Responses (paper presented at conference on Genocide: The Theory-The Reality, Yale Law School, New Haven, Conn., Feb. 16, 1991). The United Nations Special Rapporteur on Genocide has stated that the Khmer Rouge was guilty of genocide "[e]ven under the most restricted definition, since the victims included target groups such as the Chams (an Islamic minority) and the Buddhist monks." Revised and updated report on the question of the prevention and punishment of the crime of genocide prepared by Mr. B. Whitaker, 38 U.N. ESCOR Comm'n on Hum. Rts. at 10 n.17, U.N. Doc. E/CN.4/Sub.2/1985/6.

110. See, e.g., Attorney Gen. of Isr. v. Eichmann, 36 I.L.R. 18, 39 (Isr. Dist. Ct.-Jerusalem 1961), aff $d$, 36 I.L.R. 277 (Isr. Sup. Ct. 1962); RESTATEMENT (THIRD), supra note 6. $\$ 404$, reporters' note 1 (1987); Randall, supra note 58, at 836.

111. Reservations to the Convention on the Prevention and Punishment of the Crime of Genocide, 1951 I.C.J. 15, at 23.

112. See supra note 58 .

113. In a passage preceding the above-quoted language, the Court observed that "it was the intention of the United Nations to condemn and punish genocide as "a crime under international law ...." Id. The RESTATEMENT (THIRD) OF THE FOREIGN RELATIONS LAW OF THE UNITED STATES suggests that the Convention's definition of genocide also reflects customary law. RESTATEMENT (THIRD), supra note $6, \S 702$ comment d. 
Restatement (Third) of Foreign Relations Law of the United States supports this view:

A state violates customary law if it practices or encourages genocide, fails to make genocide a crime or to punish persons guilty of it, or otherwise condones genocide. Parties to the Genocide Convention are bound also by the provisions requiring states to punish persons guilty of conspiracy, direct and public incitement, or attempt to commit genocide, or complicity in genocide, and to extradite persons accused of genocide. ${ }^{114}$

In this view, customary law requires all states to punish persons who commit genocide in their territorial jurisdiction, ${ }^{115}$ while Parties to the Genocide Convention are additionally required to punish persons who participate less directly in the crime.

\section{The Convention Against Torture}

Like the Genocide Convention, the Convention Against Torture imposes an unambiguous duty to prosecute the acts it defines as criminal. ${ }^{116}$ States Parties pledge to "ensure that all acts of torture are offences under [their] criminal law,"117 and, under specified circumstances, to undertake measures to establish jurisdiction over such offenses. ${ }^{118}$ Article 7 requires that States Parties either extradite an alleged torturer or "submit the case to [their] competent authorities for the purpose of prosecution." 119

In contrast to the analogous provision in the Genocide Convention, the duty established by Article 7 was understood to be a practical and effective means

114. Id. (emphasis added).

115. For reasons indicated infra note 198 and text accompanying notes $198-99$, it is possible that the customary duty framed by the Restatement would be violated only by a complete failure to punish genocide, and not by a failure to punish every individual who participated in the crime.

116. The Inter-American Convention to Prevent and Punish Torture, supra note 92, similarly requires States Parties to criminalize torture and to punish violations. Id., arts. $6,12$.

117. Convention Against Torture, supra note 67, art. 4. Article 1 defines "torture" as:

any act by which severe pain or suffering, whether physical or mental, is intentionally inflicted on a person for such purposes as obtaining from him or a third person information or a confession, punishing him for an act he or a third person has committed or is suspected of having committed, or intimidating or coercing him or a third person, or for any reason based on discrimination of any kind, when such pain or suffering is inflicted by or at the instigation of or with the consent or acquiescence of a public official or other person acting in an official capacity. It does not include pain or suffering arising only from, inherent in or incidental to lawful sanctions.

118. Id., art. 5. This article effectively establishes a form of universal jurisdiction. See infra note 123 and accompanying text.

119. This provision was designed to ensure that "no offender would have the opportunity to escape the consequences of his acts of torture." Report of the Working Group on a Draft Convention Against Torture and Other Cruel, Inhuman or Degrading Treatment or Pumishment, 36 U.N. ESCOR Comm'n on Hum. Rts. at 11, para. 61, U.N. Doc. E/CN.4/1367 (1980). 
of suppressing torture. ${ }^{120}$ This much is evident both from statements of the drafting committee ${ }^{121}$ and from the text of the Convention, which establishes an array of domestic measures designed to assure freedom from torture. ${ }^{122}$

While focusing on domestic means of preventing torture, the Convention also establishes a form of universal jurisdiction to ensure punishment in the event a State Party fails to prosecute torturers. ${ }^{123}$ Drafted primarily to address situations in which a complicit government is unwilling to prosecute its officials for torture, ${ }^{124}$ this provision would also make it "more difficult for the perpetrators to escape the consequences of their acts by fleeing to another country."125

The explicit duty to institute criminal proceedings against alleged torturers precludes adherents to the Convention Against Torture from enacting, or at least applying, an amnesty law that forecloses prosecution of torturers. ${ }^{126}$ The committee established to monitor compliance with the Convention ${ }^{127}$ has made clear, however, that the duty arises only when the alleged torture occurred after the Convention entered into force with respect to the State Party. ${ }^{128}$

120. This difference between the Convention Against Torture and the Genocide Convention stems from the nature of the conduct proscribed in the two treaties. Genocide is, by its nature, likely to involve state complicity. Although torture, too, is often committed pursuant to state policy, it is more likely than genocide to be inflicted by state agents acting in contravention of official policy.

121. The first draft convention contained relatively weak language: "Each State Party shall, except [in the case of extradition], ensure that criminal proceedings are instituted in accordance with its national law ...." Summary Prepared by the Secretary-General in accordance with Commission Resolution 18 (XXXIV), 35 U.N. ESCOR Comm'n on Hum. Rts. at 16, U.N. Doc. E/CN.4/1314 (1978). The language of the final text of Article 7 was substituted at the suggestion of the French delegation, which urged that it was "essential to retain the principle of the advisability of instituting proceedings." Id. at 17, para. 81 .

122. E.g., Convention Against Torture, supra note 67, art. 14 (civil remedies for torture); $i d$., art. 10 (training of law-enforcement personnel).

123. Id., art. 5(2). This provision would ensure that "[n]o one guilty of torture [would] feel safe from prosecution." Summary Records of the 32nd Meeting, 40 U.N. ESCOR Comm'n on Hum. Rts. (32d mtg.) at 16, para. 85, U.N. Doc. E/CN.4/1984/SR.32 (delegate from Germany). Although some delegations were at first reluctant to accept a provision establishing universal jurisdiction, by early 1984 no state opposed its inclusion in the draft convention. See Question of the Human Rights of All Persons Subjected to any Form of Detention or Imprisonment, Torture and Other Cruel, Inhuman or Degrading Treatment or Punishment, 40 U.N. ESCOR Comm'n on Hum. Rts. (32d mtg.) at 5, para. 26, U.N. Doc. E/CN.4/1984/72.

124. See Report of the Working Group on the Draft Convention Against Torture, 38 U.N. ESCOR Comm'n on Hum. Rts. at 7, para. 40, U.N. Doc. E/CN.4/1982/L.40.

125. J. BURGERS \& H. DANELIUS, supra note 92 , at 58.

126. Nevertheless, a State Party might be allowed to enact a statute of limitations covering prosecutions for torture, provided the torture did not constitute a crime against humanity. See infra note 252 . It would, however, probably be inconsistent with a State Party's obligations under the Convention to enact a statute of limitations that failed to provide a reasonable time for instituting criminal proceedings. In a situation where criminal prosecution was foreclosed because torture was carried out pursuant to state policy, the statute of limitations should be considered to have tolled during the period when prosecutions were effectively impossible.

127. Convention Against Torture, supra note 67, art. 17.

128. At its third session, the Committee Against Torture held inadmissible three communications challenging the application of two laws enacted by the government of Argentina that precluded prosecution of military authorities allegedly responsible for torturing to death relatives of the complainants. Both laws were enacted after Argentina had signed and ratified the Convention Against Torture but before the Convention entered into force, and the torture that was the basis of the communications had occurred before the Convention was even drafted. The Committee held that the Convention did not apply to the acts, including the legislative enactments, that occurred before the Convention entered into force, but observed 


\section{Comprehensive Human Rights Conventions}

In contrast to the conventions on torture and genocide, three comprehensive human rights treaties-the International Covenant on Civil and Political Rights ("International Covenant"), ${ }^{129}$ the European Convention for the Protection of Human Rights and Fundamental Freedoms ("European Convention"), ${ }^{130}$ and the American Convention on Human Rights ("American Convention") 131-do not explicitly require States Parties to prosecute or punish violations of rights set forth in the conventions. Authoritative interpretations make clear, however, that these treaties require States Parties generally to investigate serious violations of physical integrity - in particular, torture, extra-legal executions, and forced disappearances-and to bring to justice those who are responsible. The rationale behind these duties is straightforward: prosecution and punishment are the most effective - and therefore only adequate-means of ensuring a narrow class of rights that merit special protection.

The duties derive from States Parties' affirmative obligation to ensure rights set forth in these conventions. Adherents to all three treaties pledge not only to respect enumerated rights, but also to ensure that persons subject to their jurisdiction enjoy the full exercise of those rights. ${ }^{132}$ The International Coven-

that the government of Argentina was nonetheless "morally bound to provide a remedy to victims of torture and to their dependents." O.R., M.M. and M.S. v. Argentina, Comms. Nos. 1/1988, 2/1988 and 3/1988, Decisions of the Committee against Torture under article 22 of the Convention against Torture and Other Cruel, Inhuman or Degrading Treatment or Punishment, U.N. Doc. CAT/C/3/D/1, 2, and 3/1988, Annex, para. 9 (1989).

129. See supra note 54. As of June 6, 1991, 95 countries had ratified this convention.

130. See supra note 34 . The European Convention has been ratified by 23 states.

131. See supra note 92. As of 1990,22 of the 32 member states of the Organization of American States had ratified the American Convention. This Article does not consider duties imposed by the Banjul Charter on Human and Peoples' Rights, adopted June 27, 1981, O.A.U. Doc. CAB/LEG/67/3/Rev. 5, reprinted in 21 I.L.M. 58 (1982) [hereinafter "Banjul Charter"], because the Charter does not explicitly require States Parties to investigate or prosecute violations of its substantive guarantees, and the commission established to monitor States Parties' compliance has not yet rendered any decisions interpreting the Charter.

132. A Party to the International Covenant undertakes "to respect and to ensure to all individuals within its territory and subject to its jurisdiction the rights recognized" in the convention. International Covenant, supra note 54, art. 2(1). Parties to the American Convention similarly "undertake to respect the rights and freedoms recognized [in the Convention] and to ensure to all persons subject to their jurisdiction the free and full exercise of those rights and freedoms. ..," American Convention, supra note 92, art. 1(1), and Parties to the European Convention pledge to "secure to everyone within their jurisdiction the rights and freedoms" set forth the Convention. European Convention, supra note 34, art. 1. Professor Buergenthal writes that the duty to "ensure" rights set forth in the International Covenant "implies an affirmative obligation by the state to take whatever measures are necessary to enable individuals to enjoy or exercise the rights guaranteed in the Covenant, including the removal of governmental and possibly also some private obstacles to the enjoyment of these rights." Buergenthal, To Respect and To Ensure: State Obligations and Permissible Derogations, in THE INTERNATIONAL BILL OF RIGHTS 77 (L. Henkin ed. 1981) (footnote omitted). Although the Banjul Charter differs significantly from the other comprehensive conventions, it too establishes affirmative obligations. The Charter provides that States Parties "shall recognize the rights, duties and freedoms enshrined in [the] Charter and shall undertake to adopt legislative or other measures to give effect to them." Banjul Charter, supra note 131, art. 1. It also declares that "[e]very individual shall be entitled to the enjoyment of the rights and freedoms recognized and guaranteed in the ... Charter.", id., art. 2 (emphasis added), and shall have "the right to an appeal to competent national organs against acts violating his fundamental rights. ..." Id., art. $7(1)(a)$. 
ant and American Convention further require States Parties to adopt legislation or other measures necessary to give effect to the rights and freedoms recognized in the treaties, ${ }^{133}$ and all three conventions require Parties to ensure that individuals whose rights are violated have an effective remedy before a competent body, even if the violation was committed by someone acting in an official capacity. ${ }^{134}$ To underscore the importance of ensuring the right to life through legal guarantees, each convention provides that the right to life shall be protected by law. ${ }^{135}$

\section{International Covenant on Civil and Political Rights}

The possibility of requiring States Parties to punish violations was never seriously considered by the drafters of the International Covenant. The United Nations Commission on Human Rights, which drafted the Covenant, debated extensively the nature of a State Party's duty under Article 2(3) to provide an "effective remedy" for violations of the Covenant, and in this context briefly considered explicitly requiring States Parties to punish violators. The delegate from the Philippines proposed adding a new subparagraph to Article 2(3), providing that "violators shall swiftly be brought to the law, especially when they are public officials." 136 The proposal was rejected without significant

133. International Covenant, supra note 54, art. 2(1); American Convention, supra note 92, art. 2.

134. International Covenant, supra note 54, art. 2(3); American Convention, supra note 92, art. 25; European Convention, supra note 34, art. 13. In cases challenging amnesty laws enacted in Argentina and Uruguay that are currently pending before the Inter-American Commission on Human Rights, counsel for the petitioners have argued that the laws breach the American Convention's guarantee of legal redress (Article 25), as well as States Parties' affirmative duty under Article 1(1) to "ensure" rights enumerated in the Convention. The cases are Case 10.240, E.S.M.A. (Argentina); Case 10.029, de los Santos Mendoza (Uruguay); Case 10.036, Balbi (Uruguay); Case 10.305, Menotti Cobas et al. (Uruguay); Case 10.145, Rodríguez Larreta (Uruguay); Case 10.372, Brieba (Uruguay); Case 10.372, Ortiz (Uruguay); Case 10.374, Sanjurjo Casal (Uruguay); and Case 10.375, Paitta (Uruguay). The Commission's decisions on the merits are expected to be rendered in September 1991.

135. International Covenant, supra note 54, art. 6(1); American Convention, supra note 92, art. 4(1); European Convention, supra note 34, art. 2(1). Article 6(1) of the International Covenant was intended to ensure in particular that human life is protected "against unwarranted actions by public authorities as well as by private persons." Annotations on the text of the draft lnternational Covenants on Human Rights, 10 U.N. GAOR Annex (Agenda Item 28, Part II) at 30, para. 4, U.N. Doc. A/2929 (1955). See also M. BoSSUYT, GUIDE TO THE "TRAVAUX PRÉPARATOIREs" OF THE INTERNATIONAL COVENANT ON CIVIL AND POLITICAL RIGHTS 120 (1987). Interpreting Article 2(1) of the European Convention, a former President of the European Commission of Human Rights has written that it could "reasonably be implied that the State must make the deliberate taking of life by individuals a punishable offence." J. FAWCETT, THE APPLICATION OF THE EUROPEAN CONVENTION ON HUMAN RIGHTS 37 (1987). Citing an early, unpublished decision, Fawcett wrote that a Contracting State's failure to prosecute such offenses nonetheless could not "be made the ground of an individual application to the Commission." Id., citing 809/60 Recueil (1962) i. More recently, however, a state's failure to provide for prosecution of a rapist was the ground of an individual application, resulting in a determination by the European Court of Human Rights that the state had breached Article 8 (respect for private life) of the European Convention. See infra text accompanying notes 182-88.

136. 6 U.N. ESCOR Comm'n on Hum. Rts. at 6, para. 24, U.N. Doc. E/CN.4/SR.195 (1950). The Philippine government had also prepared a proposal to add the following sentence to paragraph 2: "The perpetrators shall be duly and swiftly repressed, especially when they are public officials." This proposal was not voted upon. M. BosSUYT, sipra note 135, at 65, citing U.N. Doc. E/CN.4/365 (1950). The Philippine delegation made the following statement in support of the proposed amendment: "This addition 
discussion, ${ }^{137}$ but the general debate over Article 2(3) provides some insight into the delegates' possible concerns.

First, the Commission sought to ensure the broadest possible range of remedies for violations of human rights, and eschewed language implying that judicial remedies were the exclusive form contemplated by the Covenant. ${ }^{138}$ Second, delegates sought to avoid language that would give rise to the same consequences regardless of the seriousness of a state's infraction. ${ }^{139}$ More generally, Article 2(3) was designed principally to ensure that states provided noncriminal remedies, such as restitution or an order to desist wrongful conduct, ${ }^{140}$ and delegates may have viewed the Philippine proposal to be out of place in such an article. ${ }^{141}$

places upon the $S$ tate the responsibility of taking the initiative in the investigation and prosecution of abusive acts. The victim is too often under the influence of fear, so the Government itself should act with energy to bring the criminals swiftly to justice." Compilation of the Comments of Governments on the Draft International Covenant on Human Rights and on the Proposed Additional Articles, 6 U.N. ESCOR Comm'n on Hum. Rts. at 15, U.N. Doc. E/CN.4/365 (1950).

137. See 6 U.N. ESCOR Comm'n on Hum. Rts. at 6, para. 24, U.N. Doc. E/CN.4/SR.195 (1950). The Summary Record of the meeting in which the vote occurred reports only that, following defeat of the proposed amendment, the Philippine delegate "said that the vote should not be taken to mean that the Commission was indifferent to the fate of violators of human rights." Id., para. 25.

138. An initial draft ensuring "an effective remedy before the competent national tribunals" was opposed by the Chairwoman of the Commission, Eleanor Roosevelt, because it "appeared to imply that all violations of the Covenant would take the form of justiciable issues subject to adjudication by the courts or by the judicial process, with the usual relief given by courts, such as damages or injunctions." 6 U.N. ESCOR Comm'n on Hum. Rts. at 20, para. 74, U.N. Doc. E/CN.4/SR.138 (1950). But, she asserted, the most effective remedy for violations might sometimes lie in the political realm, through legislative action. Id. at 20-21, para. 74; see also 18 U.N. GAOR 3d Comm. at 248, para. 9, U.N. Doc. A/C.3/SR.1259 (1963) (delegate from Chile asserts that expansion of remedies to include relief from "political" branches was "in no way intended to make the political authorities the sole guardians and defenders of human rights, but simply to make available to the victims of violations of human rights the greatest possible number of remedies from the greatest possible number of authorities."); id. at 247-48, para. 8 (delegate from France asserts that in some cases, the only remedy available might come from nonjudicial bodies).

139. Commenting on the early draft language requiring States Parties to provide a remedy before "the competent national tribunals," see supra note 138, the Chairwoman said:

[W] here the exercise of discretion and judgment by administrative officials was involved it would seem highly improper to penalize government officials for errors of judgment, as distinguished from malicious misconduct. It would therefore be undesirable to require a penalty in such a case without making due allowance for the facts involved.

6 U.N. ESCOR Comm'n on Hum. Rts. at 21, para. 74, U.N. DoC. E/CN.4/SR.138 (1950). By implication, the Chairwoman seemed to regard judicial penalties to be appropriate when infractions were the product of "malicious conduct" and were otherwise appropriate in light of the "facts involved."

140. See, e.g., 18 U.N. GAOR 3d Comm. at 247, para. 8, U.N. Doc. A/C.3/SR.1259 (1963) (statement of delegate from France).

141. In virtually every legal system, civil remedies and criminal prosecutions serve different functions.

One writer describes the distinction this way:

Criminal law is generally considered to be that field of jurisprudence which is concerned with wrongs against society. Such a wrong may arise by reason of an act directed against an isolated individual, but it is the tort against the social structure, resulting from such act, which is punishable. The trial of the wrongdoer is not for the purpose of furnishing redress to the person or persons injured-that is left to the processes of the civil law. The purposes of the criminal law are rather to punish the wrongdoer for his offense against the mores of society and to deter others from acting likewise.

J. APPLEMAN, MilTTARY TRIBUNALS AND INTERNATIONAL CRMES 9 (1954); see also Koh, Civil Remedies for Uncivil Wrongs: Combatting Terrorism Throngh Transnational Public Law Litigation, 22 TEX. INT'L L.J. 169, 173 (1987) (while criminal sanctions are concerned solely with punishment and deterrence, civil 
But if the drafters did not seriously consider requiring States Parties to prosecute violations of the Covenant, ${ }^{142}$ nothing in the drafting history is inconsistent with such a duty. The text could, moreover, reasonably be interpreted to require States Parties to ensure at least some rights through use of criminal sanctions. ${ }^{143}$

The Human Rights Committee established to monitor compliance with the Covenant has, in fact, repeatedly asserted that States Parties must investigate summary executions, torture, and unresolved disappearances; bring to justice those who are responsible; and provide compensation to victims. These pronouncements stand in notable contrast to the Committee's more characteristic practice of granting states substantial leeway to determine how they will implement the Covenant ${ }^{144}$ and to fashion an appropriate remedy when found in breach of their treaty obligations. ${ }^{145}$

remedies are designed to compensate victims as well as to sanction and deter wrongdoers). Authoritative interpretations make clear that the International Covenant imposes a duty criminally to prosecute certain violations that is distinct from the duty to provide effective civil remedies. See infra text accompanying notes $147-48,155-56,160$.

142. The most extensive consideration of punishment arose during debate over Article 15. That debate reflected a strong consensus in favor of prosecuting certain violations, but the delegates were principally concerned with punishment of war criminals pursuant to principles of international law established outside the parameters of the Covenant, and not with domestic enforcement of the Covenant. Article 15(2) provides that the general ex post facto proscription set forth in Article 15(1) shall not "prejudice the trial and punishment of any person for any act or omission which, at the time when it was committed, was criminal according to the general principles of law recognized by the community of nations." The initial impetus behind this provision was the delegates' desire to ensure that Article 15(1) did not inadvertently call into question the validity of the prosecutions of war criminals at Nuremberg and Tokyo. See 2 U.N. ESCOR Comm'n on Hum. Rts. at 12, U.N. Doc. E/CN.4/SR.36 (1947); 6 U.N. ESCOR Comm'n on Hum. Rts. at 12, para. 57, U.N. Doc. E/CN.4/SR.159 (1950). But as the drafting progressed, many delegates supported the provision for more affirmative reasons as well: it would ensure that persons who committed crimes against humanity did not escape punishment simply because national law did not recognize the offense. See I5 U.N. GAOR 3d Comm. at 131, para. 20, U.N. Doc. A/C.3/SR.1007 (1960) (delegate from United Kingdom, citing prospect of amnesty being granted for genocide, argues that if "such crimes against humanity came to be considered a less serious crime than they were felt to be at present, criminals who had been guilty of them might escape scot free. That must be avoided at all costs . . ."); 15 U.N. GAOR 3d Comm. at 134, para. 3, U.N. Doc. A/C.3/SR.1008 (1960) (delegate from Poland asserts that if war crimes like those punished at Nuremberg "should be perpetrated in the future, they must be judged with the same severity ....."); id. at 135, para. 14 (delegate from Yugoslavia supports Article 15(2), which "provided that crimes against humanity should always be punished.").

143. That the duties set forth in the Covenant could be given greater precision through subsequent interpretation clearly was contemplated by the delegates to the drafting committee. See, e.g., 9 U.N. GAOR 3d Comm. at 96, para. 9, U.N. Doc. A/C.3/SR.562 (1954). Several writers have found a duty to discipline wrongdoers to be implicit in states' duty to "ensure" rights. Professor Buergenthal writes: "The obligation to 'ensure' rights creates affirmative obligations on the state-for example, to discipline its officials . . .." Buergenthal, supra note 132, at 77; see also Dinstein, The Right to Life, Physical Integrity, and Liberty, in THE INTERNATIONAL BILL OF RIGHTS 119 (L. Henkin ed. 1981) (States Parties to Covenant arguably must exercise due diligence to prevent intentional deprivation of life by individuals, "as well as to apprehend murderers and to prosecute them in order to deter future takings of life").

144. See CCPR/C/21, General comment 3/13, para. (1) (Human Rights Committee observes that the International Covenant "generally leaves it to the States Parties concerned to choose their method of implementation ....").

145. See, e.g., Varela Nuñez v. Uruguay, Comm. No. 108/1981, 38 U.N. GAOR Supp. (No. 40) Annex XXIII, para. 11, U.N. Doc. A/38/40 (1983) (State Party must provide "effective remedies pursuant to article 2(3) of the Covenant" for violating right to travel by denying complainant a passport). The Committee has, however, occasionally found that States Parties are required to perform specific acts, even when physical 


\section{a. Torture}

In "general comments" 146 interpreting Article 7 of the Covenant, which prohibits torture and cruel, inhuman or degrading treatment or punishment, the Committee has asserted:

[I]t is not sufficient for the implementation of [article 7] to prohibit [torture or other cruel, inhuman or degrading] treatment or punishment or to make it a crime. Most States have penal provisions which are applicable to cases of torture or similar practices. Because such cases nevertheless occur, it follows from article 7, read together with article 2 of the Covenant, that States must ensure an effective protection through some machinery of control. Complaints about ill-treatment must be investigated effectively by competent authorities. Those found guilty must be held responsible, and the alleged victims must themselves have effective remedies at their disposal, including the right to obtain compensation. $^{147}$

As this comment makes clear, a state's duty to investigate allegations of torture and hold the wrongdoers responsible exists over and above its duty to provide victims an effective civil remedy. ${ }^{148}$

harm is not threatened. In one case, finding a violation of the right to be free from arbitrary detention, the Committee expressed the view that the offending State should provide the detainee a "fresh trial." Sendic v. Uruguay, Comm. No. 63/1979, 37 U.N. GAOR Supp. (No. 40) Annex VII, para. 21, U.N. Doc. A/37/40 (1982); see also Magana v. Zaire, Comm. No. 90/1981, 38 U.N. GAOR Supp. (No. 40) Annex XIX, para. 9, U.N. Doc. A/38/40 (1983) (State Party is under obligation to return complainant's property). Moreover, pursuant to the Covenant's explicit provision that persons unlawfully arrested or detained "shall have an enforceable right to compensation" (Article 9(5)), the Committee has repeatedly found compensation due to victims of arbitrary detention. E.g., Viana Acosta v. Uruguay, Comm. No. 110/1981, 39 U.N. GAOR Supp. (No. 40) Annex XI, para. 15, U.N. Doc. A/39/40 (1984); Cámpora v. Uruguay, Comm No. 66/1980, 36 U.N. GAOR Supp. (No. 40) Annex VIII, paras. 19 and 20, U.N. Doc. A/36/40 (1981). The Committee has also repeatedly expressed the view that $S$ tates Parties should provide immediate medical care to detainees in cases where physical harm is threatened. See, e.g., Larrosa v. Uruguay, Comm. No. 88/1981, 38 U.N. GAOR Supp. (No. 40) Annex XVI, para. 13, U.N. Doc. A/38/40 (1983); Nieto v. Uruguay, Comm. No. 92/1981, 38 U.N. GAOR Supp. (No. 40) Annex XX, para. 12, U.N. Doc. A/38/40 (1983).

146. States Parties undertake to prepare periodic reports describing measures they have taken to implement the Covenant, and the Committee is directed to transmit both the reports and "such general comments as it may consider appropriate" to the States Parties and, if it wishes, to the Economic and Social Council. International Covenant, supra note 54, art. 40. Professor Schachter notes that some States Parties' compliance reports have made reference to "the role of procurators, ombudsmen and comparable officials who have the responsibility of investigating and instituting action against authorities who have abused their power or otherwise infringed on human rights." He observes that "ideally the procurator generals, directors of public prosecutions, and parliamentary commissioners could be effective instruments for holding governmental officials accountable for their acts." Schachter, The Obligation to Implement the Covenant in Domestic Law, in THE INTERNATIONAL BILL OF Rights 330 (L. Henkin ed. 1981). The Committee has periodically prepared "general comments" interpreting specific articles of the Covenant.

147. Report of the Human Rights Committee, 37 U.N. GAOR Supp. (No. 40) Annex V, general comment 7(16), para. 1, U.N. Doc. E/CN.4/Sub.2/Add.1/963 (1982) (emphasis added).

148. The obligatory nature of these measures is suggested by comparing the use of the term "must" in the quoted language with the word "may" in the discussion that follows. Immediately following the above-quoted passage, the Committee introduces a series of additional measures, such as training of lawenforcement personnel, with the phrase, "Among the safeguards which may make control effective are. ...." 
Whether the requirement that offenders "be held responsible" necessarily connotes criminal penalties is unclear. The United Nations Declaration on the Protection of All Persons from Being Subjected to Torture and Other Cruel, Inhuman or Degrading Treatment or Punishment ${ }^{149}$ suggests, however, that criminal punishment would be appropriate with respect to torture, while other disciplinary action might be appropriate for less serious forms of ill-treatment. ${ }^{150}$

Subsequent decisions on individual communications have reinforced the Committee's "general comment" on Article $7{ }^{151}$ For example, in Muteba $v$. Zaire, ${ }^{152}$ the Committee found that the government of Zaire had committed torture in violation of Article 7, and concluded that the government was "under an obligation to . . conduct an inquiry into the circumstances of [the victim's] torture, to punish those found guilty of torture and to take steps to ensure that similar violations do not occur in the future."153

\section{b. Extra-legal Executions}

In a case involving the arrest and subsequent killing of " 15 prominent persons . . ., including journalists, lawyers, professors and businessmen," 154 the Committee found that Surinamese military police had intentionally deprived the victims of life in violation of Article 6(1) of the Covenant, and urged the government "to take effective steps (i) to investigate the killings ... .; (ii) to

149. G.A. Res. 3452, 30 U.N. GAOR Supp. (No. 34) at 91, U.N. Doc. A/10034 (1975). This declaration was a precursor to the 1984 Convention Against Torture.

150. Article 10 of the Declaration provides that criminal proceedings should be instituted against persons who allegedly committed torture, and that, "[i]f an allegation of other forms of cruel, inhuman or degrading treatment or punishment is considered to be well founded, the alleged offender or offenders shall be subject to criminal, disciplinary or other appropriate proceedings."

151. The Committee is empowered to "receive and consider" communications from individuals who are subject to the jurisdiction of states that have ratified an Optional Protocol and who claim to have suffered a violation of any of the rights protected by the Covenant. Optional Protocol to the International Covenant on Civil and Political Rights, G.A. Res. 2200A, 21 U.N. GAOR Supp. (No. 16) at 59, art. 1, U.N. Doc. A/6316 (1966). While the Optional Protocol does not empower the Committee to order states to afford remedies for violations, it authorizes the Committee to "forward its views to the State Party concerned and to the individual" after considering the communication in closed session. Id., art. 5(4) and (3). In practice, the Committee has expressed (and published) its views as to whether States Parties' conduct violates their duties under the Covenant, and regarding the steps that should or must be taken to rectify a breach. Pursuant to Article 4I of the Covenant, States Parties can also recognize the competence of the Committee to receive inter-state complaints and to attempt conciliation between the complaining state and the state allegedly in breach of its obligations. No such complaint has ever been filed. See supra note 89 .

152. Comm. No. 124/1982, 39 U.N. GAOR Supp. (No. 40) Annex XIII, U.N. Doc. A/39/40 (1984).

153. Id., para. 13. Curiously, in a case preceding Muteba v. Zaire, the Committee found the Uruguayan government responsible for torture but did not state that an investigation or prosecution was required. The Committee did, however, express the view that the government was "under an obligation . . . to take steps to ensure that similar violations do not occur in the future," Estrella v. Uruguay, Comm. No. 74/1980, 38 U.N. GAOR Supp. (No. 40) Annex XII, para. 11, U.N. Doc. A/38/40 (1983), a mandate broad enough to include investigation and prosecution. See also Gilboa v. Uruguay, Comm. No. 147/1983, 41 U.N. GAOR Supp. (No. 40) Annex VIII, U.N. Doc. A/41/40 (1985).

154. Baboeram v. Suriname, Comm. Nos. 146/1983 and 148-154/1983, 40 U.N. GAOR Supp. (No. 40) Annex X, para. 13.2, U.N. Doc. A/40/40 (1985). 
bring to justice any persons found to be responsible for the death of the victims: (iii) to pay compensation to the surviving families; and (iv) to ensure that the right to life is duly protected in Suriname." ${ }^{155}$ Similarly, finding the government of Uruguay in breach of Article 6 for the death-in-detention of Hugo Haroldo Dermit Barbato, the Committee expressed "the view that the State party is under an obligation to take effective steps ... to establish the facts of Hugo Dermit's death, to bring to justice any persons found to be responsible for his death and to pay appropriate compensation to his family." 156

\section{c. Disappearances}

Although "disappearances" are not proscribed as such in the International Covenant, ${ }^{157}$ the Committee has interpreted the Covenant to impose a duty to "investigate, punish and compensate" when disappearances occur. In the Bleier $^{158}$ and Quinteros ${ }^{159}$ cases, the Committee concluded that the government of Uruguay should take effective steps: (a) to establish what had happened to the victims, and, in the Quinteros case, to secure the victim's release from detention; (b) to bring to justice any persons found to be responsible for the victims' disappearance and ill-treatment and, in the Bleier case, for the victim's

155. Id, para. 16. In earlier "general comments" on Article 6, the Committee alluded to a duty to punish, but did not elaborate: "The Committee considers that States Parties should take measures not only to prevent and punish deprivation of life by criminal acts, but also to prevent arbitrary killing by their own security forces." Report of the Human Rights Committee, 37 U.N. GAOR Supp. (No. 40) Annex V, para. 3, U.N. Doc. E/CN.4/Sub.2/Add.1/963 (1982).

156. Dermit v. Uruguay, Comm. No. 84/1981, 38 U.N. GAOR Supp. (No. 40) Annex IX, para. 11.a, U.N. Doc. A/38/40 (1983) (emphasis added). In one case in which the Committee found a State Party's conduct to have violated Article 6, it found compensation due but did not urge the State to undertake an investigation and prosecution. In that case, however, the government had already carried out an administrative inquiry into the incident, dismissed responsible police officers and criminally prosecuted the alleged offenders. The defendants were acquitted on the basis of an emergency decree in force at the time of their conduct; the Human Rights Committee expressed the view that "the right to life was not adequately protected by the law of Colombia as required by article 6 (1)," Camargo v. Colombia, Comm. No. R.11/45, 37 U.N. GAOR Supp. (No. 40) Annex XI, para. 13.1, U.N. Doc. A/37/40 (1982), and that "the State party should take the necessary measures ... to ensure that the right to life is duly protected by amending the law." Id., para. 15.

157. A "disappearance" is a forced abduction by agents of the state, followed by a complete denial of knowledge of the victim's whereabouts and of other forms of accountability by state officials. Disappearances violate the right to be free from arbitrary arrest and detention, which is protected by guarantees set forth in Articles 9 and 14. When followed by torture or summary execution, a disappearance also entails a violation of Article 7 or 6, respectively. In "general comments" on Article 6, the Committee has observed that ". . . States should establish effective facilities and procedures to investigate thoroughly cases of missing and disappeared persons in circumstances which may involve a violation of the right to life." Report of the Human Rights Committee, 37 U.N. GAOR Supp. (No. 40) Annex V, U.N. Doc. E/CN.4/Sub.2/Add.1/963 (1982).

158. Bleier v. Uruguay, Comm. No. R.7/30, 37 U.N. GAOR Supp. (No. 40) Annex X, U.N. Doc A/37/40 (1982).

159. Quinteros v. Uruguay, Comm. No. 107/1981, 38 U.N. GAOR Supp. (No. 40) Annex XXII, U.N. Doc. $A / 38 / 40$ (1983). 
probable death; (c) to pay compensation for the wrongs suffered; and (d) to ensure that similar violations do not occur in the future. ${ }^{160}$

Because the Committee has not set forth a rationale for its views in these cases, it is not clear whether it regards investigation and punishment to be generally required when torture, extra-legal killings, or disappearances occur, or merely the most appropriate response in the cases it has considered. ${ }^{161}$ The distinction may, in any event, be inconsequential. Implicit in the Committee's decisions is the view that investigation and prosecution are the most effective means of securing the right to life and the right to be free from torture and forced disappearance. In view of the paramount importance that the Committee has attached to these three rights, it is reasonable to assume that States Parties must use the most effective means available to ensure their enjoyment. ${ }^{162}$

Under this interpretation of the Committee's jurisprudence, prosecution leading to an appropriate sanction is generally required when a disappearance, an extra-legal execution, or torture is credibly alleged. Some departures from

160. Bleier v. Uruguay, Comm. No. R.7/30, 37 U.N. GAOR Supp. (No. 40) Annex X, para. 15, U.N. Doc. A/37/40 (1982); Quinteros v. Uruguay, Comm. No. 107/1981, 38 U.N. GAOR Supp. (No. 40) Annex XXII, para. 16, U.N. Doc. A/38/40 (1983). The Committee's views in the Quinteros case make clear that a duty to clarify the fate of the "disappeared" is owed to the victim's family for reasons distinct from the deterrence rationale supporting the general duty to investigate possible criminal conduct. The case had been submitted by the mother of a woman who had been missing for five years. The Committee found that, in light of the "anguish and stress caused to the mother by the disappearance of her daughter and by the continuing uncertainty concerning her fate and whereabouts ... [ [the mother] too is a victim of the violations of the Covenant suffered by her daughter in particular, of article 7." Accordingly, the Committee asserted, the mother "has the right to know what has happened to her daughter." Id., para. 14.

The duty to investigate, prosecute and provide compensation may not apply if the disappearance is later acknowledged and the victim survives. In Dermit the Committee found the government of Uruguay in violation of Article 6 because of the death-in-detention of Hugo Dermit and in violation of Articles 9 and 14 because of the arbitrary arrest and detention of Guillermo Dermit. Guillermo Dermit's arrest and detention was unacknowledged for 17 days, leading the Committee to assert that he "disappeared on 2 December 1980." Dermit v. Uruguay, Comm. No. 84/1981, 38 U.N. GAOR Supp. (No. 40) Annex IX, para. 8.3, U.N. Doc. A/38/40 (1983). While finding the government liable to provide an investigation, prosecution and compensation with respect to Hugo Dermit's death, in his younger brother's case the Committee found Uruguay responsible for "ensur[ing] strict observance of all the procedural guarantees prescribed by ... the Covenant"; for transmitting a copy of its views to Guillermo Dermit; and for ensuring that similar violations did not recur. Id., para. 11. Compare A. \& H. Sanjuan Arevalo v. Colombia, Comm. No. 181/1984, 45 U.N. GAOR Supp. (No. 40) Annex IX, para. 11, U.N. Doc. A/45/40 (1989) (in case involving unresolved disappearance of two brothers, Committee finds breach of Articles 6 and 9 despite ongoing investigations and disciplinary proceedings by State Party).

Although the decisions in Bleier, Quinteros and Sanjuan Arevalo implied that disappearances are a continuing violation of the Covenant as long as the fate of the victim is unresolved, the Committee has held inadmissible a communication concerning disappearances that took place before the Covenant entered into force with respect to the respondent state, even though the victims' fate had never been clarified. S.E. v. Argentina, Comm. No. 275/1988, 45 U.N. GAOR Supp. (No. 40) Annex X, para. 5.3, U.N. Doc. A/45/40 (1990).

161. In the Bleier case the Committee "urge[d]" the government of Uruguay to take the steps enumerated supra; in the subsequent Quinteros case it expressed the view that the government "should" take those steps.

162. This interpretation of the Committee's jurisprudence is similar to another legal argument advanced by several international law experts: Under both customary and conventional law, a narrow class of fundamental rights are nonderogable. If governments are required to uphold those rights in all circumstances, including situations of public emergency, they should not be permitted to suspend operation of the legal machinery necessary to ensure the rights. See Goldman, supra note 5, at 11; see also Part III, Section B. 
this norm might be justified, however. The clearest justification would be evidentiary constraints, provided they were not the product of government malfeasance. A measure of flexibility is implied, moreover, in the Committee's use of such phrases as "bring to justice" and "hold responsible." While these terms seem to contemplate appropriately severe criminal penalties, in some instances administrative disciplinary procedures might satisfy a state's duty. Clearly, however, a State Party's routine failure to punish extra-legal killings, torture, and disappearances would constitute a breach of its duties.

While the Committee has made clear that punishment plays a necessary part in States Parties' fulfillment of certain duties under the Covenant, it has stopped short of recognizing a right by individuals to ensure that a particular person is prosecuted. In H.C.M.A. v. the Netherlands, ${ }^{163}$ the Committee rejected the complainant's claim that Article 14(1) of the Covenant, which guarantees the right to a fair trial, establishes a right "to see another person criminally prosecuted."164

\section{American Convention on Human Rights}

The American Convention, like the International Covenant, has been interpreted to require States Parties to investigate and punish serious violations of physical integrity. ${ }^{165}$ In its first contentious case, ${ }^{166}$ the Inter-American Court of Human Rights interpreted Article 1(1) of the American Convention to impose on each State Party a "legal duty to take reasonable steps to prevent human rights violations and to use the means at its disposal to carry out a serious investigation of violations committed within its jurisdiction, to identify those responsible, to impose the appropriate punishment and to ensure the victim adequate compensation." 167 The decision was rendered in the Velás-

163. Comm. No. 213/1986, 44 U.N. GAOR Supp. (No. 40), U.N. Doc. A/44/40 (1989).

164. Id., para. 11.6. The complainant had unsuccessfully challenged a Dutch military prosecutor's decision not to prosecute a police officer who had allegedly maltreated the complainant at the time of his arrest. There was no suggestion in the Committee's decision that failure to prosecute police for violating citizens' rights was a general pattern in the Netherlands. The Committee noted that the Dutch Parliament was then considering legislation that would enable citizens to appeal decisions by the military prosecutor not to prosecute cases-a right already available with respect to civilian prosecutors' determinations. Id., paras. 4.4 and 4.5; see also S.E. v. Argentina, Comm. No. 275/1988, 45 U.N. GAOR Supp. (No. 40) Annex X, para. 5.5, U.N. Doc. A/45/40 (1990) (citing H.C.M.A. v. the Netherlands in dictum).

165. The travaux preparatoires contain little indication that punishment was contemplated as a necessary means of enforcing the American Convention. Discussion of the role of the judiciary arose principally in the context of Article 25, which establishes a right to effective remedies, and of provisions prohibiting arbitrary arrest and detention and ensuring due process protections for criminal defendants.

166. The Court is empowered both to render advisory opinions interpreting the Convention (as well as other treaties concerning the protection of human rights in the Americas), American Convention, supra rote 92 , art. 64 , and to consider "contentious cases" alleging a violation of the Convention by a State Party that has recognized its competence, id., art. 62. See generally Buergenthal, The Inter-American Court of Human Rights, 76 AM. J. INT'L L. 231 (1982); Méndez \& Vivanco, Disappearances and the Inter-American Court: Reflections on a Litigation Experience, 13 HAMLINE L. REv. 507, 527-30 (1990).

167. Velásquez Rodríguez Case, Inter-Arn. Ct. H.R. (ser. C) No. 4, para. 174 (1988) (judgment). The Velasquez Rodríguez Case was one of three cases filed with the Court by the Inter-American Commission 
quez Rodríguez Case, brought by the Inter-American Commission on Human Rights against the government of Honduras for the unresolved disappearance of Manfredo Velásquez in September 1981. Although the fate of the victim could not be established conclusively, the Court heard testimony indicating that he had been tortured and killed by Honduran security forces.

The Court found the Honduran government responsible for multiple violations of the American Convention, basing much of its analysis on the affirmative duties established by Article 1(1). ${ }^{168}$ Writing of the duty, pursuant to Article 1(1), to "ensure" rights set forth in the Convention, the Court asserted:

This obligation implies the duty of the States Parties to organize the governmental apparatus and, in general, all the structures through which public power is exercised, so that they are capable of juridically ensuring the free and full enjoyment of human rights. As a consequence of this obligation, the States must prevent, investigate and punish any violation of the rights recognized by the Convention and, moreover, if possible attempt to restore the right violated and provide compensation as warranted for damages resulting from the violation . . . . ${ }^{169}$

These obligations are not fulfilled if an investigation is a "mere formality preordained to be ineffective"; instead, it "must be undertaken in a serious manner . . . "170 Significantly, the Court found that Honduras' duties under the Convention persisted even though the government in power at the time of its decision was not the same one that had presided over the practice of disappearances whose victims included Manfredo Velásquez. ${ }^{171}$

on Human Rights alleging Honduran government responsibility for disappearances, and was the first to result in a decision on the merits. The chief findings summarized below were affirmed in the judgment of January 20, 1989 in the Godínez Cruz Case, Inter-Am. Ct. H.R. (ser. C) No. 5 (1989). The Court did not find the Honduran government responsible for the disappearances alleged in the third companion case. See Fairén Garbi and Solís Corrales Case, Inter-Am. Ct. H.R. (ser. C) No. 6, para. 158 (1989) (judgment).

168. See supra note 132. The Court found Article $I(1)$ to be "essential" in determining whether conduct infringing one of the rights set forth in the Convention could be attributed to the government, giving rise to state responsibility for a violation of the Convention. Velásquez Rodríguez Case, Inter-Am. Ct. H.R. (ser.

C) No. 4, para. 164 (1988) (judgment).

169. Id., para. 166 (emphasis added). Similarly, the Court asserted:

The State is obligated to investigate every situation involving a violation of the rights protected by the Convention. If the State apparatus acts in such a way that the violation goes unpunished and the victim's full enjoyment of such rights is not restored as soon as possible, the State has failed to comply with its duty to ensure the free and full exercise of those rights to the persons within its jurisdiction. The same is true when the State allows private persons or groups to act freely and with impunity to the detriment of the rights recognized by the Convention.

Id., para. 176; see also id., para. 174.

170. Id., para. 177. The Court implied that an investigation undertaken by the same body accused of responsibility for alleged disappearances prima facie fails to satisfy this standard. See id., para. 180.

171. The Court wrote:

According to the principle of the continuity of the State in international law, responsibility exists both independently of changes of government over a period of time and continuously from the time of the act that creates responsibility to the time when the act is declared illegal. The foregoing is also valid in the area of human rights although, from an ethical or political point of view, the attitude of the new government may be much more respectful of those rights than that of the government in power when the violations occurred. 
Although the judgment suggested that a duty to punish applies to "every" violation of the American Convention, ${ }^{172}$ it is unlikely that the Court intended the obligation to extend to all violations, regardless of the severity of the breach. Instead, the Court's reasoning should, pending further clarification, be confined to the especially serious violations raised in the case before it-disappearances, probable torture, and probable extra-judicial execution. ${ }^{173}$

The judgment in the Velásquez Rodríguez Case was prefigured by numerous decisions of the Inter-American Commission on Human Rights interpreting the American Declaration of the Rights and Duties of Man ${ }^{174}$ ("American Declaration") and the American Convention. ${ }^{175}$ In cases involving violations of Article I of the Declaration, which assures the right to life, liberty, and personal security, the Commission has repeatedly recommended that the offending state "order a thorough and impartial investigation" and, in accordance with domestic law, "punish the individual or individuals responsible."176 It has similarly recommended that States Parties to the American Convention investigate serious

Id., para. 184. The Court emphasized that the duty to clarify the fate of someone who has disappeared, and to inform the victim's relatives of the results of these efforts, persists as long as the victim's fate remains uncertain. Id., para. 181.

172. Id., para. 176.

173. It is also unclear why the Court, in ordering remedies, did not direct the Honduran government to institute criminal proceedings against those responsible for the disappearance of Manfredo Velásquez. The most likely explanation is that the Court viewed the acts of declaring Honduras in breach of its duties and of enunciating States Parties' affirmative obligations under the American Convention to be less of an intrusion on sovereignty than ordering the government to institute criminal proceedings. $C f$. T. MERON, supra note 57 , at 145 (decisions ordering injunctive relief "tend to generate tension between international authority and state sovereignty," whereas "a declaration of a right by an international judicial body does not significantly clash with the right of a sovereign state to choose the necessary remedies"). Still, the Court found that Honduras was required to pay compensation to the victim's relatives. See Velásquez Rodriguez Case, Inter-Am. Ct. H.R. (ser. C) No. 4, para. 194(5) (1988) (judgment). In its judgments on damages in Velasquez and Godinez, the Court referred to its earlier judgments on the merits as establishing a duty to prevent, investigate and punish violations and stated that the duty remains binding until the government fully complies. Judgment of July 21, 1989 (damages), Velásquez Rodriguez Case, paras. 34-36; Judgment of July 21, 1989 (damages), Godinez Cruz Case, paras. 32-34.

174. Adopted May 2, 1948, OEA/ser.L./V/II.23, doc. 21 rev. 6 (1979).

175. The Commission was created to further respect for human rights among O.A.S. member states. Declaration at the Fifth Meeting of Consultation of Ministers of Foreign Affairs, Santiago, Chile, Aug. 1218, 1959, Final Act, OAS Official Records, OEA/ser.C./II.5, at 4-6 (1959). The Commission's statute provides that it promotes the observance of human rights. "Human rights" refers to rights set forth in the American Convention in relation to States Parties, and to rights set forth in the American Declaration with respect to other states that are O.A.S. members. Statute of the Inter-American Commission on Human Rights, art. 1. In 1965, the Second Special Inter-American Conference empowered the Commission to examine communications alleging human rights violations, to request information from the relevant government, to make appropriate recommendations and to publish observations on matters covered in the communications in its annual report. Resolution XXII, "Expanded Functions of the Inter-American Commission on Human Rights," Final Act of the Second Special Inter-American Conference, OAS/ser.E./XIII.1, at 45-46 (1965). The American Convention, adopted five years later, explicitly authorizes the Commission to receive both individual and inter-state petitions alleging violations of the Convention by States Parties. 1985 INTER-AM. Y.B. ON HUM. RTS. 66-68. For a description of the Commission's powers and activities, see Méndez \& Vivanco, supra note 166 , at 519-27.

176. Case 1870, INTER-AM. C.H.R. 52, OEA/ser.L./V/II.43, doc. 21 (1978); see also Case 1967, INTERAM. C.H.R. 55, OEA/ser.L./V/II.43, doc. 21 (1978); Case 1783, para. 3, IACHR, TEN YEARS OF ACTIVITIES, 1971-1981 at 142-46; Case 2126, INTER-AM. C.H.R. 77, OEA/ser.L./V/II.47, doc. 13 rev. 1 (1979); Case 2088, INTER-AM. C.H.R. 38, OEA/ser.L.N/II.50, doc. 13 rev. 1 (1980). 
violations of physical integrity and that they "try and punish those responsible for their occurrence," as well as provide compensation. ${ }^{177}$

Despite these decisions, in 1986 the Commission expressed a general inclination to allow national authorities to determine the validity of amnesty laws enacted by previous governments, subject to the qualification that the truth about past violations must be fully known. ${ }^{178}$ More recently, however, the Commission's Chairman has voiced strong opposition to amnesty laws that foreclose prosecution of atrocious crimes:

A compact by which a whole nation is called upon to suspend its memories of torture, murder, forcible "disappearances" of loved ones, a compact which would have citizens pretend that the tragic losses and suffering which they have undergone never occurred, this ... is no bargain. This is not amnesty; it is forcible amnesia. The "peace" that is bought at this price is supported by a thread slenderer even than the thread by which the sword of Damocles was suspended. ${ }^{179}$

The Chairman suggested that such amnesties violate rights set forth in the American Convention and Declaration: "The rights set out in the American Convention on Human Rights and in the American Declaration of the Rights and Duties of Man by their very nature cannot be subject to extinction by national fiat."

\section{European Convention for the Protection of Human Rights and Fundamental Freedoms}

The European Court and Commission of Human Rights ${ }^{180}$ have had comparatively few occasions to elucidate the role of punishment in securing rights set forth in the European Convention. Decisions of both bodies make clear, however, that punishment plays a part in Contracting States' fulfillment of certain duties under the Convention. ${ }^{181}$

177. E.g., Case 10.150, Informe 3/90 (Suriname), OEA/ser.L./V/II.77, doc. 23, at 14 (1990).

178. INTER-AM. HUM. RTS., OEA/ser.L./V/II.68, doc. 8 rev.1 (1986).

179. Speech by Ambassador Oliver H. Jackman before the First Committee of the XIX Regular Meeting of the General Assembly to Present the Annual Report of the IACHR, Nov. 1989.

180. The European Commission can receive both individual petitions and inter-state complaints alleging violations of the Convention by Contracting States. European Convention, supra note 34, arts. 24, 25. When it finds a petition admissible, the Commission attempts a friendly settlement of the dispute. When this cannot be achieved, the Commission prepares a detailed report setting forth its finding of facts and its conclusions regarding whether there has been a breach of the Convention. Id., arts. 28-31. Within three months of the transmittal of such reports to the parties and to the Council of Ministers, the government-parties or the Commission can refer the case to the European Court of Human Rights. Id., art. 48. If the Court determines that it has jurisdiction over the case, it determines whether there has been a breach of the Convention; its judgment is final and binding. Id., arts. 50, 52. See generally Higgins, The European Convention on Human Rights, in 2 HuMAN RIGHTS IN INTERNATIONAL LAW: LEGAL AND POLICY ISSUES 505-11 (T. Meron ed. 1984).

181. The European Commission has, however, repeatedly rejected claims that Article 6 of the Convention, which guarantees the right to a fair trial, establishes a right to have criminal proceedings instituted 
In $X$ and $Y$ v. Netherlands, ${ }^{182}$ the Court found the Dutch government in breach of the European Convention by virtue of a gap in Dutch law that had precluded a victim of rape from instituting criminal proceedings against her attacker. The victim, Miss Y, was mentally handicapped, and had been deemed incompetent to initiate a criminal complaint. The relevant provision of the Netherlands Criminal Code could be invoked only by a victim, and Miss Y's attacker escaped prosecution. ${ }^{183}$

The Court found that the respondent state's failure to provide for prosecution of Miss Y's assailant violated its affirmative duty to secure her enjoyment of the right to respect for private life, as guaranteed in Article 8 of the Convention. Acknowledging that in general Contracting States enjoy a "margin of appreciation" in determining the means they will use to secure rights protected by Article $8,{ }^{184}$ the Court found, nonetheless, that only the criminal law is an adequate means of protecting the crucial values at stake in this case:

[T] he protection afforded by the civil law in the case of wrongdoing of the kind inflicted on Miss $Y$ is insufficient. This is a case where fundamental values and essential aspects of private life are at stake. Effective deterrence is indispensable in this area and it can be achieved only by criminal-law provisions; indeed, it is by such provisions that the matter is normally regulated. ${ }^{185}$

On this basis, the Court rejected the Dutch government's claim that the applicant's ability to seek civil damages or an injunction against her attacker discharged its duties under the Convention. ${ }^{186}$ Finding the Dutch government partly responsible for the harm suffered by the applicant in consequence of her rape, the Court ordered the government to pay compensation. ${ }^{187}$

against officials or third persons. See, e.g., X v. Federal Republic of Germany, 24 Collection of Decisions 50, 61-62 (1967); Kiss v. United Kingdom, 7 Decisions and Reports 55, 64 (1976).

182. 91 Eur. Ct. H.R. (ser. A) (1985) (judgment).

183. Miss Y's father believed her to be incapable of signing a complaint, and signed one on her behalf. The police officer who received the complaint also regarded Miss $Y$ to be incapable of signing the complaint in light of her "mental condition." Id., paras. 9-10. Despite the father's complaint, the public prosecutor decided not to prosecute the attacker provided he did not repeat the crime. Id., para. 11. The victim's father appealed this decision to a Court of Appeal. The appeal was dismissed on the ground that the principal provision of Dutch criminal law that might have been a basis for prosecution could be invoked only if the victim herself took action-but this was precluded by virtue of her incapacity. $I d$., para. 12. The gap in protection afforded by Dutch law was narrow; under most provisions of the Netherlands Criminal Code establishing sexual offenses, institution of criminal proceedings did not require a complaint by the victim. See id., paras. 15, 27. Still, the lacuna was substantial enough to place the Dutch government in breach of the European Convention. See id., para. 30; infra text accompanying notes 184-87.

184. 91 Eur. Ct. H.R. (ser. A), para. 24 (1985) (judgment).

185. Id., para. 27.

186. See id., paras. 24-25. The Court noted that the Delegate of the European Commission of Human Rights had argued that "the need for protection existed erga omnes, whilst an injunction could only be directed to a limited circle of persons," and that "the civil law lacked the deterrent effect that was inherent in the criminal law." Id., para. 26.

187. Id., para. 40. The only remedial power explicitly given the Court under the European Convention is to "afford just satisfaction to the injured party." European Convention, supra note 34, art. 50. The Court 
In their analyses of the European Convention's admissibility requirement that applicants exhaust domestic remedies, the Court and Commission have indirectly affirmed the principle that punishment plays a necessary part in Contracting States' duty to secure certain rights set forth in the Convention. ${ }^{188}$ Both bodies have found that applicants need not exhaust domestic remedies if their complaint concerns an "administrative practice," 189 characterized by "repetition of acts, and official tolerance." 190 The term "official tolerance" means

that, though acts of torture or ill-treatment are plainly illegal, they are tolerated in the sense that the superiors of those immediately responsible though cognisant of such acts, take no action to punish them or prevent their repetition; or that higher authority, in face of numerous allegations, manifests indifference by refusing any adequate investigation of their truth or falsity, or that in judicial proceedings, a fair hearing of such complaints is denied. ${ }^{191}$

can afford just satisfaction if it finds that a Contracting Party has violated the Convention and the Party's domestic law "allows only partial reparation to be made for the consequences" of the breach. Id. In Ireland v. United Kingdom, the Court held that it "cannot direct the respondent State to institute criminal or disciplinary proceedings against those members of the security forces" found to have violated Article 3 by inflicting cruel, inhuman or degrading treatment on detainees or against "those who condoned or tolerated such breaches." Ireland v. United Kingdom, 25 Eur. Ct. H.R. (ser. A) at 95, concluding para. 10 (1978) (judgment); see also id. at 72, para. 187.

188. In various other contexts, the Commission has seemingly assumed that criminal prosecution plays a necessary part in Contracting States' fulfillment of their duty to secure certain fundamental rights. For example, the headnote to one decision, in which the Commission rejected a claim that the U.K. government should have done more than it did to prevent the murder of the applicant's brother by Irish Republican Army terrorists, asserts: "The obligation to protect the right to life is not limited for the High Contracting Parties to the duty to prosecute those who put life in danger but implies positive preventive measures appropriate to the general situation. In the present case, however, this obligation did not go so far as to provide individual protection." Mrs. W. v. United Kingdom, 32 Collection of Decisions 190, 190 (1983) (emphasis added). (Curiously, the decision itself is not so explicit in recognizing a "duty to prosecute those who put life in danger." The Commission noted that an alleged killer was awaiting trial for murder, id. at 199, para. 10, and that the applicant had argued that the European Convention required the U.K. to take measures beyond criminal prosecution to protect the right to life. Id., para. 11. But its conclusions on this issue were confined to the observation that the Convention "may indeed give rise to positive obligations on the part of the State," id. at 200 , para. 12, and that the Commission "cannot find that the United Kingdom was required under the Convention to protect the applicant's brother by measures going beyond those actually taken by the authorities ...." id., para. 15.) The Commission's report of the friendly settlement reached in the case of France. Norway. Denmark. Sweden and The Netherlands $v$. Turkey noted that measures taken by Turkey to respond to allegations of torture included "criminal prosecutions and convictions concerning cases of torture." 8 EUR. HUM. RTS. REP. 205, 213 (1985).

189. The Court has defined an administrative practice as "an accumulation of identical or analogous breaches which are sufficiently numerous and inter-connected to amount not merely to isolated incidents or exceptions but to a pattern or system. . . ." Ireland v. United Kingdom, 25 Eur. Ct. H.R. (ser. A) at 64, para 159 (1978) (judgment). Where there is an administrative practice, the Commission has reasoned, the assumption underlying the exhaustion requirement-that an effective remedy is available in domestic law-does not apply. The Greek Case, 1969 Y.B. EuR. Conv. ON HUM. RTS. 194, paras. 24, 25 (Eur. Comm'n of Hum. Rts.).

190. Id. at 195 , para. 28.

191. Id. at 196 , para. 29 (emphasis added). 
The European Court has termed such a practice "incompatible" with the European Convention, ${ }^{192}$ reasoning that "under the Convention [higher State] authorities are ... under a duty to impose their will on subordinates and cannot shelter behind their inability to ensure that it is respected."193

\section{Customary Law: Disappearances, Extra-legal Executions, and Torture}

Although publicists disagree about the range of human rights protected by customary law, ${ }^{194}$ there is general agreement that customary law prohibits torture, disappearances, and extra-legal executions and that these prohibitions are peremptory norms. ${ }^{195}$ But if the legal status of these prohibitions is clear, their precise meaning is not. Some experts believe that a single violation of a right protected by customary law engages international responsibility, while others assert that state responsibility is generated only when violations have occurred on a systematic basis ${ }^{196}$ or as a matter of state policy. ${ }^{197}$

Still less clear is whether customary law's prohibition of torture, extra-legal killing, and involuntary disappearance imports a duty to prosecute violations when they occur, or whether, instead, customary law requires only that governments not directly inflict these abuses. Even under the latter view, however, it is necessary to determine what constitutes sufficiently direct government participation in violations to generate state responsibility.

The Restatement (Third) of the Foreign Relations Law of the United States adopts the view that a complete failure to punish repeated or notorious violations of rights protected by customary law renders a government sufficiently complicit to generate state responsibility. Asserting that a state violates customary law "if, as a matter of state policy, it practices, encourages or condones," inter alia, torture, murder, or disappearances, ${ }^{198}$ the Restatement suggests that

192. Ireland v. United Kingdom, 25 Eur. Ct. H.R. (ser. A) at 64, para. 159 (1978) (judgment).

193. Id. The Court linked this obligation to Contracting States' affirmative duty to "secure" rights:

The Convention does not merely oblige the higher authorities of the Contracting States to respect for their own part the rights and freedoms it embodies; as is shown by Article 14 [rights in Convention to be "secured" without discrimination on any ground], and . . . Article 1 ("shall secure"), the Convention also has the consequence that, in order to secure the enjoyment of those rights and freedoms, those authorities must prevent or remedy any breach at subordinate levels. Id. at 91 , para. 239.

194. For discussion of different catalogues of human rights protected by customary law, see T. MERON, supra note 57 , at $94-99$.

195. See RESTATEMENT (THIRD), supra note $6, \S 702$ comment $\mathrm{n}$ and reporters' note 11 ; J. BURGERS \& H. DANELIUS, supra note 92, at 12; Goldman, supra note 5, at 4. For general discussion of peremptory norms (rules that have jus cogens status), see M. MCDOUGAL, H. LASSWELL \& L. CHEN, HUMAN RIGHTS AND WORLD PUBLIC ORDER 338-50 (1980); I. BROWNLIE, supra note 57, at 512-517; see also Vienna Convention, sipra note 62, art. 53.

196. For discussion of these issues, see T. MERON, supra note 57, at 103.

197. RESTATEMENT (THIRD), supra note $6, \S 702$.

198. Id. Other practices which the Restatement identifies as violations of customary law are genocide; slavery or slave trade; cruel, inhuman, or degrading treatment or punishment; prolonged arbitrary detention; systematic racial discrimination; and a consistent pattern of gross violations of internationally recognized human rights. Id. 
"[a] government may be presumed to have encouraged or condoned [these] acts ... if such acts, especially by its officials, have been repeated or notorious and no steps have been taken to prevent them or to punish the perpetrators." 199

The Restatement's approach is not novel. Arbitral tribunals have interpreted the traditional rule of customary law establishing state responsibility for injury to aliens to require states to "act vigorously and diligently to punish crimes against aliens." ${ }^{200}$ The analysis of the Mexican-American Claims Commission in the Janes case evokes the reasoning of the Restatement: "If the nonprosecution and nonpunishment of crimes (or of specific crimes) in a certain period and place occurs with regularity such nonrepression may even assume the character of a nonprevention and be treated as such."201

A wide range of activities of the United Nations and other intergovernmental organizations reinforce the view that punishment plays a necessary part in states' duty under customary law to ensure the rights to life, freedom from torture, and freedom from involuntary disappearance. For example, reports prepared by Special Rapporteurs, Special Representatives, and Working Groups appointed by the Commission on Human Rights of the United Nations to report on human rights conditions in particular countries ${ }^{202}$ or on particular types of human rights violation $\mathrm{s}^{203}$ have repeatedly condemned governments' failure to punish torture, disappearances, and extra-legal executions. ${ }^{204}$ Echoing the

199. Id., comment b.

200. Id., $\$ 711$, reporters' note 2, citing the following decisions of Mexican-American Claims Commission: Kennedy, G.C.C. 289 (1926) (responsibility generated by failure to impose adequate penalty); Mallen, id. at 254 (1927) (responsibility generated by failure to enforce penalty); West, id. at 404 (1927) (amnesty and pardon unduly granted).

201. In re Janes (U.S. v. Mex.), 4 REP. INT'L ARB. AwARDS $82,89-90$ (1926). In this case the Commission ordered the Mexican government to provide damages to the United States on behalf of relatives of a United States citizen whose murder had been inadequately investigated by Mexican authorities, constituting a denial of justice.

202. Reports have been prepared on such countries as Chile, El Salvador, Afghanistan, Iran, and Guatemala. Reports have also been prepared by special "experts" appointed by the Commission to provide advisory services in the field of human rights to particular governments. The latter, like the former, have given substantial attention to the role of investigation and prosecution of serious human rights violations. See, e.g., Report on Haiti by the Expert, Mr. Philippe Texier, prepared in conformity with Commission on Human Rights resolution 1989/73, 46 U.N. ESCOR Comm'n on Hum. Rts., paras. 55, 61, 67, 87, 91, 102, 106 (c) \& (e), U.N. Doc. E/CN.4/1990/44; Report by the Expert, Mr. Héctor Gros Espiell, on Guatemala, prepared in accordance with paragraph 9 of Commission resolution 1989/74, 46 U.N. ESCOR Comm'n on Hum. Rts., paras. 48, 49, 57, 66(c), U.N. Doc. E/CN.4/1990/45.

203. "Theme" rapporteurs and working groups have been appointed to report upon such violations as religious discrimination, torture, disappearances, extra-legal executions, and arbitrary detention. For discussion of three of the theme rapporteurs, see Weissbrodt, The Three "Theme" Special Rapporteurs of the UN Commission on Human Rights, 80 AM. J. INT'L L. 685 (1986).

204. These reports often cite the International Covenant, various U.N. human rights declarations and customary international law as the bases of the rights examined. Several resolutions adopted by the Commission on Human Rights suggest that a duty to prevent human rights violations may inhere in member states' human rights obligations under the U.N. Charter, a legally binding instrument. Article I provides that the purposes of the United Nations include the achievement of international cooperation "in promoting and encouraging respect for human rights ...." Pursuant to Articles 55 and 56 of the Charter, member states pledge to take action to achieve "universal respect for, and observance of, human rights." In language that evokes the human rights provisions of the Charter, the United Nations Commission on Human Rights has asserted "that the obligation to promote and protect human rights and fundamental freedoms calls not 
reasoning of the Restatement, these reports have asserted that a state's failure to punish repeated violations of physical integrity encourages further violations. ${ }^{205}$ Although these reports are not authoritative interpretations of international law, resolutions of the U.N. General Assembly have endorsed many of the reports' conclusions regarding punishment of persons responsible for torture, disappearances, and extra-legal executions. ${ }^{206}$

The duty to prosecute grave violations of physical integrity has been rendered explicit in a number of international instruments drafted in recent years. These include the Inter-American Convention to Prevent and Punish Torture; ${ }^{207}$ a Draft Declaration on the Protection of All Persons From Enforced or Involuntary Disappearances ${ }^{208}$ prepared under United Nations auspices; ${ }^{209}$ a Draft Inter-American Convention on the Forced Disappearance of Per-

only for measures to guarantee the protection of human rights and fundamental freedoms but also for measures intended effectively to prevent any violation of those rights." Comm'n on Hum. Rts. Res. 1988/51; Comm'n on Hum. Rts. Res. 1988/50.

205. E.g., Report prepared by the Special Rapporteur on the situation of human rights in Chile in accordance with paragraph 11 of the Commission on Human Rights resolution 1983/38 of 8 March 1983, U.N. Doc. A/38/385, para. 341 (1983) (impunity enjoyed by Chilean security organs "is the cause, and an undoubted encouragement in the commission, of multiple violations of fundamental rights"); Final report on the situation of human rights in El Salvador submitted to the Commission on Human Rights by Mr. Jose Antonio Pastor Ridruejo in fulfillment of the mandate conferred under Commission resolution 1986/39, 43 U.N. ESCOR Comm'n on Hum. Rts. at 13, para. 60, U.N. Doc. E/CN.4/1987/21 (failure of Salvadoran courts to render convictions that bear reasonable relationship to number of violations of right to life creates "climate of impunity"); Report of the Working Group on Enforced or Involuntary Disappearances, 45 U.N. ESCOR Comm'n on Hum. Rts. at 85, para. 312, U.N. Doc. E/CN.4/1989/18 (impunity in the face of repeated disappearances "creates conditions conducive to the persistence of such practices"); Report of the Working Group on Enforced or Involuntary Disappearances, 47 U.N. ESCOR Comm'n on Hum. Rts. at 86, para. 406 ("impunity is perhaps the single most important factor contributing to the phenomenon of disappearance. Perpetrators of human rights violations . . . become all the more irresponsible if they are not held to account before a court of law.").

206. E.g., G.A. Res. 37/185, para. 10 (1982) (urging Salvadoran judiciary to "assume its obligation to ... prosecute and to punish those found responsible for assassinations, acts of torture and other forms of cruel, inhuman or degrading treatment"); G.A. Res. 36/157, para. 4(e) (1981) (urging Chilean authorities to "investigate and clarify the fate of persons who have disappeared for political reasons, to inform the relatives of those persons of the outcome of the investigation and to prosecute and punish those responsible for such disappearances"); G.A. Res. 33/173, para. 1(b) (1978) (calling upon governments to "ensure that law enforcement and security authorities or organizations are fully accountable, especially in law, in the discharge of their duties, such accountability to include legal responsibility for unjustifiable excesses which might lead to enforced or involuntary disappearances. . ..").

207. Supra note 92.

208. U.N. Doc. E/CN.4/1991/49 [hereinafter "Draft Declaration on Disappearances"].

209. The draft declaration provides that every state "shall ensure that all forms of partipation in enforced or involuntary disappearance . . . are specific crimes of the gravest kind under its criminal law," $i d$., art. 4, and that, "[w] henever there are reasonable grounds to believe that an enforced or involuntary disappearance has been committed, the State shall promptly refer the matter [for an impartial] investigation, even if there has been no formal complaint." Id., art. 13(1). The draft further provides that states shall ensure that a person alleged to have committed a disappearance is brought to justice either through prosecution or extradition "regardless of the individual's nationality or the place where the offence was committed." Id., art. 14. The draft also asserts a duty to ensure that persons alleging that an involuntary disappearance has occurred have a right to file a complaint and to have the complaint promptly and impartially investigated. Id., art. 13(1). 
sons; ${ }^{210}$ and Principles on the Effective Prevention and Investigation of Extralegal, Arbitrary and Summary Executions ${ }^{211}$ endorsed by the U.N. General Assembly. ${ }^{212}$ While not conclusive, the frequent reiteration of a duty to punish grave violations of physical integrity in international instruments is evidence that the duty is-or is emerging as-a customary norm. ${ }^{213}$

\section{E. Customary Law: Crimes Against Humanity}

The search for legal standards governing transitional societies' policy toward past abuses has led to renewed interest in the substantive law generated by the Nuremberg prosecutions. Several analysts and organizations interpret that law to require punishment of crimes against humanity. ${ }^{214}$ While their view is wellfounded, the law of crimes against humanity is difficult to apply, in part because the meaning of the term is shrouded in ambiguity. With no precedent

210. INTER-AM. C.H.R. 352, OEA/ser.L.V/II.74, doc. 10 rev. 1 (1988). The draft convention requires States Parties "to prevent and to punish the perpetrators of forced disappearance of persons," id., art. 1, and to establish jurisdiction over acts constituting forced disappearances committed in their jurisdiction and under several other circumstances. Id., art. 5. The draft convention also provides that "perpetrators of forced disappearances shall not benefit from any legal act adopted by the Executive or Legislative branches of government that might have the effect of exempting such persons from punishment." Id., art. 8.

211. Ecosoc. Res. 1989/65, Annex (endorsed by G.A. Res. 44/162 (1989)). These principles, which seek to give effect to the internationally-recognized right to life, provide, inter alia:

1. Governments shall prohibit by law all extra-legal, arbitrary and summary executions and shall ensure that any such executions are recognized as offences under their criminal laws, and are punishable by appropriate penalties which take into account the seriousness of such offences.

The first principle appearing under the heading "Investigation" begins: "9. There shall be a thorough, prompt and impartial investigation of all suspected cases of extra-legal, arbitrary and summary executions . . .." The Principles further establish a duty to "bring to justice" persons identified in the investigation under the principle aut dedere aut judicare (either extradite or try). Id., para. 18. The Special Rapporteur on Summary or Arbitrary Executions has expressed the view that "[a]ny Government's practice that fails to reach the standards set out in the principles may be regarded as an indication of the Government's responsibility, even if no government officials are found to be directly involved in the acts of summary or arbitrary execution." Report by the Special Rapporteur, Mr. S. Amos Wako, pursuant to Economic and Social Council resolution 19S8/38, 46 U.N. ESCOR Comm'n on Hum. Rts. at 105, para. 463, E/CN.4/1990/22.

212. Moreover principles designed to implement the Declaration of Basic Principles of Justice for Victims of Crime and Abuse of Power, G.A. Res. 40/34, 40 U.N. GAOR Supp. (No. 53) at 213, U.N. Doc. $A / 40 / 53$ (1985), call upon states to investigate deaths and serious injuries apparently caused by law enforcement or other professional personnel and to prosecute or extradite those who are responsible. Implementation Principles $R 4(d) .5$ and $R 4(d) .6$, reprinted in INTERNATIONAL PROTECTION OF VICTIMS 31-32 (M. Bassiouni ed. 1988). The implementation principles also prohibit immunity from prosecution for public officials and agents. Id., Implementation Principle $R 4(d) .8$.

213. See Filartiga v. Peña-Irala, 630 F.2d 876, 882-884 (2d Cir. 1980); T. MERON, supra note 57, at 93-94. Further evidence that a rule has attained the status of customary law may be found in the practice of states in their diplomatic relations. In this regard it is noteworthy that the U.S. government has repeatedly pressed foreign governments to prosecute serious human rights violations. See, e.g., Salvador Promises Quayle Full lnquiry on Jesuits, N.Y. Times, Jan. 28, 1990, at A3, col. 1; Salvadoran Chief, in U.S., Vows to Solve Jesuit Case, N.Y. Times, Sept. 25, 1990, at A3, col. 3: Samuel T. Dickens, Assassins in Managua, N.Y. Times, April 16, 1991, at A23, col. 2 (opinion piece).

214. Sce, e.g., AMERICAS WATCH CHILE REPORT, supra note 3, at 84; HUMAN RIGHTS WATCH, SPECIAL ISSUE: ACCOUNTABILITY FOR PAST HUMAN RIGHTS ABUSES 2 (Dec. 1989); Zalaquett, From Dictatorship to Democracy: Kicking Out the Generals Is Only the First Chapter, THE NEW REPUBLIC, Dec. 16, 1985, at 20; see also Rogers, supra note 5, at 276; AMERICAS WATCH, TRUTH AND PARTIAL JUSTICE IN ARGENTINA 81 (1987) [hereinafter AMERICAS WATCH ARGENTINA REPORT]. 
to guide them, the Nuremberg tribunals developed somewhat differing interpretations of the scope of the crime. ${ }^{215}$ Subsequent legal developments have done little to clarify the issues raised by Nuremberg case law: the most significant efforts to clarify and codify the law applied at Nuremberg have occurred outside the rubric of crimes against humanity, ${ }^{216}$ and various efforts to enlarge the scope of the crime have generated more controversy than consensus. ${ }^{217}$ Further, it is not immediately obvious that Nuremberg law establishes an obligation to punish crimes against humanity; the most controversial legal issue surrounding the prosecution of those crimes at Nuremberg was whether the Allied nations had the power to prosecute acts committed by German nationals against other Germans. ${ }^{218}$

But if the law of crimes against humanity is somewhat lacking in clarity, its normative implications are clear. The Nuremberg precedent, as subsequently ratified, reflects the international community's resolve that atrocious crimes carried out as part of a mass campaign of persecution must not go unpunished.

215. See infra note 231. Although prosecuting German nationals for offenses against other Germans represented an innovation in international law, the offense of crimes against humanity had been prefigured by the 1907 Hague Convention's reference to "laws of humanity" as a principle governing the conduct of international war, Preamble, Fourth Hague Convention Respecting the Laws and Customs of War on Land, done October 18, 1907, 36 Stat. 2277, T.S. No. 539; a 1915 declaration of the governments of France, Great Britain and Russia describing the massacres of Armenians in Turkey as "crimes against humanity," see HISTORY OF THE UNITED NATIONS WAR CRIMES COMMISSION AND THE DEVELOPMENT OF THE LAW OF WAR 189, compiled by the United Nations War Crimes Commission, His Majesty's Stationery Office (1948); and the determination of a commission appointed by the Preliminary Peace Conference at the conclusion of World War I that the Allied nations should prosecute "persons belonging to to enemy countries . . . who have been guilty of offences against . . . the laws of humanity," quoted in Schwelb, supra note 79, at 181.

216. Crimes against humanity prosecuted at Nuremberg fell into two categories: 1) violations of the rights of civilian populations in German-occupied territories, and 2) violations of the rights of civilian populations in Germany. The first category overlapped with the category of "war crimes" subject to the jurisdiction of the IMT, and some offenses prosecuted at Nuremberg were found simultaneously to constitute war crimes and crimes against humanity. Crimes against humanity that were also war crimes were subsequently codified and clarified, along with other rules of humanitarian law, in the four Geneva Conventions of 1949. Although each of the conventions requires High Contracting Parties to punish certain offenses that were punishable as war crimes/crimes against humanity under the Nuremberg Charter, see supra note 100, the term "crimes against humanity" does not appear in any of the four conventions. The Genocide Convention establishes a duty to punish the principal crime against humanity committed in German territory against German nationals-genocide-but its definition of the crime is not coextensive with crimes against humanity punished at Nuremberg. The conduct made punishable by the Convention does not require a nexus to war, and in that respect is broader than crimes against humanity as defined in the Charter. See infra text accompanying notes 220, 229. But the Convention's definition of genocide is narrower than the Charter's definition of crimes against humanity insofar as the former imposes an intent requirement that was not included in the Charter. Moreover the Genocide Convention excludes "political groups" from targets of genocide; in contrast, the Nuremberg Charter included political grounds as a basis of persecution constituting a crime against humanity. See infra text accompanying note 220 . While numerous other conventions adopted since World War II have expanded the catalogue of rights that governments must assure to individuals subject to their jurisdiction, these conventions generally have not purported to develop the law of crimes against humanity.

217. See infra text accompanying notes $238-40$.

218. See supra text accompanying notes 70-83. 


\section{Definition of Crimes Against Humanity}

Article 6(c) of the Nuremberg Charter, as amended by the so-called "Berlin Protocol," ${ }^{219}$ defined crimes against humanity as:

murder, extermination, enslavement, deportation, and other inhumane acts committed against any civilian population, before or during the war, or persecutions on political, racial or religious grounds in execution of or in connection with any crime within the jurisdiction of the Tribunal, whether or not in violation of the domestic law of the country where perpetrated. ${ }^{220}$

The definition of crimes against humanity set forth in Control Council Law No. 10 , which established the jurisdiction of military tribunals operating in the Allied Powers' respective zones of occupation, ${ }^{221}$ closely tracked the Charter definition. ${ }^{222}$

As interpreted by the IMT and the U.S. Military Tribunals in Nuremberg, ${ }^{223}$ crimes against humanity had several elements. First, they comprised only grave crimes such as murder and extermination, and not less serious forms of "inhumane acts." 224 Second, inhumane acts constituted crimes against hu-

219. Executed Oct. 6, 1945, E.A.S. No. 472.

220. Nuremberg Charter, supra note 83, art. 6(c). The Berlin Protocol substituted a comma for a semicolon between "war" and "or" in the English and French texts of Article 6(c). The Protocol essentially brought the English and French texts into conformity with the Russian text.

221. Article III of Control Council Law No. 10, which was adopted by the Allied Powers on December 20,1945 , delegated to each occupying power the right to arrest suspected war criminals and to initiate prosecutions within its zone. For data relating to prosecutions undertaken pursuant to this instrument, see A. RUCKERL, THE INUESTIGATION OF NAZI CRIMES 1945-1978, at 29-31 (1980).

222. Article II(I)(c) defined Crimes against Humanity as:

Atrocities and offences, including but not limited to murder, extermination, enslavement, deportation, imprisonment, torture, rape, or other inhumane acts committed against any civilian population, or persecutions on political, racial or religious grounds whether or not in violation of the domestic laws of the country where perpetrated.

223. See supra note 72. The twelve prosecutions undertaken by U.S. tribunals in Nuremberg began in October 1946 and ended in April 1949. The U.S. tribunals prosecuted 185 defendants who had held important positions in the German High Command, government ministries, private industry, the Gestapo, the SS and other organizations.

224. See infra note 227 . The definition of crimes against humanity in both the Charter and Control Council Law potentially covered a sweeping range of conduct. Both instruments defined the crime to include not only enumerated acts such as murder and extermination, but also "other inhumane acts," and the Control Council Law used the phrase "including but not limited to ... "in its enumeration of acts constituting crimes against humanity. See supra text accompanying note 220 and supra note 222 . But as one legal expert observed, applying the eiusdem generis rule, the term "other inhumane acts" in Article 6(c) of the Charter should be interpreted to include "only' serious crimes of a character similar to murder, extermination, enslavement, and deportation." Schweib, supra note 79, at 191. This principle of construction is equally pertinent to the enumerated "inhumane acts" set forth in Control Council Law No. 10, which specifically mentions imprisonment, rape and torture in addition to the acts set forth in the Charter's definition. Applying the eiusdem generis rule, the term "imprisonment" should probably be understood to refer to the type of internment in concentration camps for which Nazis were prosecuted by the Allied nations. 
manity only when committed on a mass scale. ${ }^{225}$ Further, despite language in the Charter and Control Council Law indicating that "inhumane acts" and "persecutions" are distinct crimes against humanity, ${ }^{226}$ the decisions of various Nuremberg tribunals suggest that "persecution" constitutes a crime against humanity only when it entails atrocious "inhumane acts." 227 Summing up the law generated by the twelve post-IMT prosecutions in Nuremberg, Brigadier General Telford Taylor, United States Chief of Counsel for War Crimes, wrote that "the concept of 'crimes against humanity' comprises atrocities which are part of a campaign of discrimination or persecution."228

225. This element is implied in the phrase "any civilian population," which appears in both the Charter and Control Council Law's definition of crimes against humanity. A U.S. military tribunal endorsed this interpretation of the Control Council Law in the Justice Case. Making clear that it was interpreting Control Council Law No. 10 in a manner consistent with its view of international law, the tribunal asserted "that crimes against humanity as defined in C. C. Law 10 must be strictly construed to exclude isolated cases of atrocity or persecution." United States v. Altstoetter (Case No. 3), II TRIALS OF WAR CRIMINALS, supra note 68 , at 982; see also id. at 984-85. The tribunal noted that, although the record was "replete with evidence of specific criminal acts," they were "not the crimes charged in the indictment," but instead constituted "evidence of the intentional participation of the defendants and serve as illustrations of the nature and effect of the greater crimes charged in the indictment." Id. at 985. Still, defendants in the Einsatzgruppen Case were charged with direct responsibility for numerous specific atrocities, and a particular murder was also specifically charged in the Ministries Case. See TAYLOR REPORT, supra note 32, at 73. Thus, it appears that individual instances of murder and the like were punishable as crimes against humanity if undertaken as part of a mass program of similar crimes.

According to one writer, the Supreme Court of the British Zone found in one case that a mass element was not essential to the legal definition of crimes against humanity since isolated acts, such as torture or rape, fall within the concept of "inhumane acts." Meyrowitz, La répression par les tribunaux allemands des crimes contre l'humanité et de l'appartenance da une organisation criminelle en application de la loi no. 10 du Conseil de contrôle allié (Paris 1960), at 347, cited in Fourth Report on the Draft Code of Offences against the Peace and Security of Mankind, U.N. Doc A/CN.4/398, at 59, para. 44 (1986). Yet any "isolated acts" considered in the British-prosecuted case presumably took place in the context of massive Nazi atrocities. Although some writers have asserted that a mass element is not necessarily integral to crimes against humanity, see id. at 58-59, paras. 33-42, the view asserted in the Justice Case is a more authoritative statement of the law.

226. See supra text accompanying note 220 and supra note 222.

227. For example the tribunal that presided over the Flick Case concluded that discriminatory expropriation of Jewish property did not constitute a crime against humanity. Applying the eiusdem generis rule, the tribunal reasoned that the phrase "other persecutions" in Control Council Law No. 10 "must be deemed to include only such as affect the life and liberty of the oppressed peoples." United States v. Flick (Case No. 5), VI TRIALS OF WAR CRIMINALS, supra note 68, at 1215. Citing the Flick Case, the tribunal that presided over the I.G. Farben Case ruled that plunder and spoliation of properties located in Germanoccupied countries, while constituting war crimes, "would not constitute crimes against humanity, as the acts alleged related wholly to offenses against property." United States v. Krauch (Case No. 6), VIII TRIALs OF WAR CRIMINALS, supra note 68, at 1129 . The tribunal that presided over the Ministries Case found that certain decrees that discriminated against Jews in food rationing, while evincing "rank discrimination" and a "callous social sense," did not produce sufficiently harsh consequences to constitute crimes against humanity. United States v. von Weizsaecker (Case No. 11), XIV TRIALS OF WAR CRMinals, supra note 68 , at 558 .

228. TAYLOR REPORT, supra note 32, at 64; see also id. at 69 (referring to crimes against humanity as "atrocities committed in the course or as a result of racial or religious persecutions"). The quintessential crime against humanity punished at Nuremberg was genocide. Although neither the Charter nor IMT used this term, it appeared in the indictment of the Major War Criminals. U.S. prosecutors frequently charged defendants with genocide in the subsequent Nuremberg trials, and various U.S. Military Tribunals cited genocide as the principal crime against humanity committed by Nazi defendants. E.g., United States v. Altstoetter (Case No. 3), III TRIALS OF WAR CRIMINALS, supra note 68, at 983; United States v. Greifelt (Case No. 8), IV TRIALS OF WAR CRMINALS, supra note 68, at 88. Rendered before the United Nations 
Finally, crimes against humanity were punished at Nuremberg only if they had a nexus to war. ${ }^{229}$ The legal status of the nexus requirement-then and now-is ambiguous, however. The IMT interpreted Article 6(c) generally to exclude acts of persecution against Germany's Jewish population committed before the onset of war in 1939, but the judgment left unclear whether the tribunal believed the nexus requirement to be an element of crimes against humanity as prohibited by the law of nations, or merely a limitation on its jurisdiction. ${ }^{230}$ Decisions of U.S. "tribunals in subsequent Nuremberg trials failed to resolve this ambiguity. ${ }^{231}$ And while post-Nuremberg developments have

adopted the Genocide Convention, these judgments generally used the term "genocide" in a less restrictive sense than it was defined in that Convention. For example in the Justice Case the U.S. tribunal cited the definition of genocide set forth in a then recently-adopted resolution of the United Nations General Assembly, which declared genocide to be "a denial of the right of existence of entire human groups ... " United States v. Altstoetter, supra, at 983 (quoting The Crime of Genocide, G.A. Res. 96 (I), U.N. Doc. A/64/Add.1, at 188 (1946)).

229. By substituting a comma for a semi-colon in the Charter's definition of crimes against humanity, see supra note 220, the Berlin Protocol indicated that the phrase "in execution of or in connection with any crime within the jurisdiction of the Tribunal" qualified the entire definition of crimes against humanity, and not just acts involving persecution. See Schwelb, supra note 79, at 188. As previously noted, the other two crimes subject to the jurisdiction of the IMT were crimes against peace and war crimes. See supra text accompanying note 83 .

230. After reviewing conduct involving persecution of Jews in Germany before 1939, the IMT, which declared that it was "bound by the Charter, in the definition which it gives [of] Crimes against Humanity," IMT Judgment, supra note 60 , at 248 , concluded:

The Tribunal is of the opinion that revolting and horrible as many of these crimes were, it has not been satisfactorily proved that they were done in execution of, or in connection with, any [crime within the jurisdiction of the Tribunall. The Tribunal therefore cannot make a general declaration that the acts before 1939 were Crimes against Humanity within the meaning of the Charter, but from the beginning of the war in 1939 War Crimes were committed on a vast scale, which were also Crimes against Humanity; and insofar as the inhumane acts charged in the Indictment, and committed after the beginning of the war, did not constitute War Crimes, they were all committed in execution of, or in connection with, the aggressive war, and therefore constituted Crimes against Humanity.

Id. at 249 (emphasis added). See generally Clark, Crimes Against Humanity, in THE NUREMBERg TRIAL AND INTERNATIONAL LAW 195-96 (G. Ginsburgs \& V. Kudriavtsev eds. 1990) (expressing view that, in applying nexus requirement, the IMT was concerned with questions of its jurisdiction and proof, and not with concept of crimes against humanity more broadly).

231. Although the definition of crimes against humanity set forth in Control Council Law No. 10 closely tracked the Charter definition, it omitted the language requiring a nexus to a war-related offense. Sce supra note 222. Other provisions suggested, however, that the linkage persisted in the Control Council law. The Preamble asserted that the law "was enacted to give effect to the . . London Agreement of 8 August, 1945 and the Charter issued pursuant thereto," and Article I provided that the Nuremberg Charter was made an integral part of the Control Council Law.

The judgment in one case brought under this law asserted that crimes against humanity were not limited to war-related acts, United States v. Ohlendorf (Case No. 9), IV TRIALS OF WAR CRIMINALS, supra note 68 , at 499 , and the decision in another case contained language that was supportive of this view. United States v. Altstoetter (Case No. 3), III TRIALS OF WAR CRIMINALS, supra note 68, at 974, 979. But two other tribunals concluded that they had no jurisdiction over conduct charged as crimes against humanity that occurred before the war. United States v. Flick (Case No. 5), VI TRIALS OF WAR CRMINALS, supra note 68, at 1213; United States v. von Weizsaecker (Case No. 11), XIV TRIALS OF WAR CRIMINALS, supra note 68 , at 553,558 . 
tended to free crimes against humanity from a wartime context, ${ }^{232}$ the trend has been inconclusive. ${ }^{233}$

If post-Nuremberg developments have failed decisively to resolve the nexus issue, they have removed the requirement's justification. Subsequent ratification of the principles of law applied by the $\mathrm{IMT}^{234}$ has obviated the ex post facto concerns underlying insistence on the nexus requirement at Nuremberg. ${ }^{235}$ And there are compelling reasons to punish crimes against humanity regardless of their nexus to war. As Justice Jackson, Chief of Counsel for the United States, argued in his opening speech before the IMT, a crime against humanity is an offense that becomes the concern of the international community not only when its repercussions literally traverse national borders, but also when (and because) it surpasses "in magnitude and savagery any limits of what is tolerable by modern civilization." 236 Punishment of such conduct-whether or not connected to war-is necessary to vindicate constitutional principles of the international legal order. ${ }^{237}$

A variety of post-Nuremberg efforts to enlarge the scope of crimes against humanity have brought more confusion than clarity to the term's meaning. These initiatives range from U.N. resolutions, conventions, and other documents denouncing apartheid and other forms of racial discrimination as crimes against

232. See Carey, Procedures for International Protection of Human Rights, 53 IowA L. REv. 291, 299 (1967) and infra notes $233,238-39$.

233. A codification of the "Nürnberg Principles" adopted by the United Nations General Assembly in 1950 preserved a nexus requirement, but the principles were intended to be a restatement of Charter/LMT law rather than of potentially broader international law. Report of the International Law Commission to the General Assembly, 5 U.N. GAOR Supp. (No. 12) at 11, U.N. Doc. A/1316 (1950), reprinted in [1950] 2 Y.B. INT'L L. COMM'N 374. When, at the request of the General Assembly, the International Law Commission (ILC) prepared a Draft Code of Offenses Against the Peace and Security of Mankind, it omitted a nexus-to-war element from the definition of crimes against humanity set forth in this draft international criminal code. See 1954 U.N.Y.B. at 409. In the ILC's fourth report on the draft code, its Special Rapporteur asserted that the autonomy of crimes against humanity from war crimes "has now become absolute. Today, crimes against humanity can be committed not only within the context of an armed conflict, but also independently of any such conflict." Fourth Report on the Draft Code of Offences Against the Peace and Security of Mankind, by Mr. Doudou Thiam, Special Rapporteur, 38 U.N. GAOR C.4 at 56, U.N. Doc. A/CN.4/398 (1986). But the draft code remains just that, and is unlikely to be adopted in the foreseeable future-if ever. Various other international instruments purporting to expand the concept of crimes against humanity have omitted a nexus requirement, but these have failed to command the consensus necessary to generate a new rule of customary international law. See infra text accompanying notes 238-40.

234. See infra text accompanying notes 241-45.

235. See supra text accompanying notes 70-74, 82-83.

236. Opening Speech of Justice Robert H. Jackson, supra note 75, at 127.

237. Violations of fundamental human rights committed on a mass scale are, in general, of paramount concern in international penal law. This is reflected in the ILC's Draft Articles on State Responsibility, which provide that "international crimes"-a term the ILC uses to refer to crimes of a state rather than of an individual-include "a serious breach on a widespread scale of an international obligation of essential importance for safeguarding the human being, such as those prohibiting slavery, genocide and apartheid." Draft Articles on State Responsibility, art. 19, para. 3(c), [1976] 2 Y.B. INT'L L. COMM'N (pt. 2), at 95, U.N. Doc. E/CN.4/Ser.A/1976/Add.1 (Part 2) (1977). Cf. T. MERON, supra note 57, at 215 (ILC's "concept of state crimes suggests that the international community cannot be relied upon to tolerate endlessly certain egregious violations of human rights"). 
humanity ${ }^{238}$ to a draft international criminal code including breaches of international obligations essential to safeguarding the environment in its definition of the crime. ${ }^{239}$ Although numerous, efforts to broaden the scope of crimes against humanity have typicaily failed to garner broad consensus. ${ }^{240}$

238. E.g., G.A. Res. 2022, 20 U.N. GAOR Supp. (No. 14) at 150, para. 4, U.N. Doc. A/6014 (1966) (condemning "the policies of racial discrimination and segregation practised in Southern Rhodesia, which constitute a crime against humanity"); G.A. Res. 2074, 20 U.N. GAOR Supp. (No. 14), para. 4, U.N. Doc. A6014 (1966) (condemning "the policies of apartheid and racial discrimination practised by the Government of South Africa in South West Africa, which constitute a crime against humanity"); G.A. Res. 2189, para. 6 (1967) (declaring "that the practice of apartheid, as also all forms of racial discrimination, constitutes a crime against humanity"); G.A. Res. 2202, para. 1 (1966) (condemning "the policies of apartheid practised by the Government of South Africa as a crime against humanity"); Convention on the Non-Applicability of Statutory Limitations to War Crimes and Crimes Against Humanity, opened for signature Nov. 26, 1968, 754 U.N.T.S. 73, G.A. Res. 2391, 23 U.N. GAOR Supp. (No. 18) at 40, art. 1(b), U.N. Doc. A/7218 (1968); and Apartheid Convention, supra note 66 , art. 1. The former convention incorporated apartheid-related conduct in its definition of crimes against humanity, and added a new category-eviction by armed attack or occupation. This clause was proposed by representatives of the United Arab Republic and Lebanon, who argued that Israel's occupation practices had resulted in "some of the most evil crimes against humanity which were being committed at present." Quoted in Miller, The Convention on the Non-Applicability of Statutory Limitations to War Crimes and Crimes Against Humanity, 65 AM. J. INT'L L. 476, 490 (1971). The apartheid resolutions and conventions enlarge the concept of crimes against humanity beyond that recognized by the Nuremberg tribunals, which effectively linked the element of "persecution" to "inhumane acts" entailing extraordinary savagery, such as mass extermination and enslavement. See supra text accompanying notes 226-28. While apartheid itself may not constitute a crime against humanity under customary law, atrocious crimes carried out on a mass scale as a means of enforcing apartheid would fall squarely within the definition of the customary law crime. Outside the rubric of crimes against humanity, systematic racial discrimination violates customary law. RESTATEMENT (THIRD), supra note $6, \S 702$.

239. Fourth report on the Draft Code of Offences against the Peace and Security of Mankind, by Mr. Doudou Thiam, Special Rapporteur, 38 U.N. GAOR C.4 at 86, U.N. Doc. AVCN.4/398 (1986). In addition, the General Assembly of the Organization of American States has affirmed that involuntary disappearances constitute crimes against humanity. E.g., AG/RES.742 (XIV-0/84); AG/RES.666 (XIII-0/83). See also Velásquez Rodríguez Case, Inter-Am. Ct. H.R. (ser. C) No. 4, para. 153 (1988) (judgment); Godínez Cruz Case, Inter-Am. Ct. H.R. (ser. C) No. 5, para. 161 (1989) (judgment) (noting that international doctrine and practice have often characterized disappearances as crimes against humanity); see also Draft Inter-American Convention on the Forced Disappearance of Persons, supra note 210, art. 4 (declaring forced disappearance to be a crime against humanity). There can be no doubt that forced disappearances constitute "inhumane acts" within the Nuremberg Charter's definition of crimes against humanity. See supra text accompanying note 224. Moreover the type of disappearances condemned by the O.A.S. General Assembly would generally fall within the rubric of politically-based persecutions recognized in the Charter definition; disappearances in Latin America have typically been directed against perceived political opponents of the government. If, however, the O.A.S. resolutions purport to recognize disappearances as crimes against humanity regardless of the scale on which they are carried out (this is unclear from the text of the resolutions), the O.A.S. actions would enlarge the crime beyond that recognized by the Nuremberg tribunals. See supra note 225 and accompanying text. While such an expansion might enjoy the consensus necessary to establish a new rule of customary law within the Inter-American system, a similarly strong consensus probably has not yet emerged beyond the O.A.S. member countries. The U.N. Sub-Commission on the Prevention of Discrimination and Protection of Minorities has, however, suggested that the Economic and Social Council request the U.N. General Assembly to invite the ILC to consider including disappearances in its draft code of offences against the peace and security of mankind, with a view to declaring disappearances a crime against humanity. E.S.C. Res. 1982/12, U.N. Doc. E/1982/12.

240. In contrast to the General Assembly's 1948 resolution recognizing genocide as an international crime, supra note 228 , which was adopted unanimously, the previously-cited resolutions condemning apartheid as a crime against humanity were adopted by a predominantly African-Asian majority, with most Western nations abstaining. See Goldenberg, Crimes Against Humanity-1945-1970, 10 WESTERN ONT. L. REV. 1, 38 (1971). Similarly, the Convention on the Non-Applicability of Statutory Limitations to War Crimes and Crimes Against Humanity, supro note 238, was supported by less than half of the member states of the United Nations. Miller, supra note 238, at 477. Much of the dissension surrounding this convention pertained to its inclusion of apartheid and "eviction" as crimes against humanity. See generally id. The 
In contrast, the international community has been far more united in affirming the law of crimes against humanity applied at Nuremberg. Significant acts of ratification include the following:

*On December 11, 1946, the United Nations General Assembly unanimously adopted a resolution "[a]ffirm[ing] the principles of international law recognized by the Charter of the Nürnberg Tribunal and the judgment of the Tribunal."241

*On November 21, 1947, the General Assembly established the International Law Commission (ILC) as a permanent body whose purpose would be to promote "the progressive development of international law and its codification," 242 and adopted a resolution directing the ILC to "[f]ormulate the principles of international law recognized in the Charter of the Nürnberg Tribunal and in the judgment of the Tribunal." 243 On December 12, 1950, the General Assembly adopted the "Nürnberg Principles" prepared by the ILC pursuant to its earlier resolution. ${ }^{244}$

*The principles of law applied at Nuremberg subsequently were incorporated into the municipal law of numerous countries. ${ }^{245}$

The Nuremberg principles of law have had an enduring impact on one category of offenders in particular: Nazi war criminals. Many countries have prosecuted Nazi criminals in the decades since the Nuremberg prosecutions were concluded, ${ }^{246}$ and efforts to bring World War II criminals to justice continue to the present day. ${ }^{247}$

Convention's provisions relating to crimes against humanity were so controversial that another convention on the same subject was subsequently drafted under the auspices of the Council of Europe. Dinstein, supra note 57, at 232. The European Convention on the Non-Applicability of Statutory Limitation to Crimes Against Humanity and War Crimes, opened for signature Jan. 25, 1974, reprinted in 13 I.L.M. 540 (1974), omits apartheid from its definition of crimes against humanity.

241. Affirmation of the Principles of International Law recognized by the Charter of the Nürnberg Tribunal, G.A. Res. 95(I), U.N. Doc. A/64/Add.1, at 188 (1946).

242. G.A. Res. 174 (II) Annex, art. 1(1) (1947).

243. G.A. Res. 177 (II), para. (a) (1947).

244. Report of the International Law Commission to the General Assembly, 5 U.N. GAOR Supp. (No. 12) at 11-14, U.N. Doc. A/1316 (1950).

245. R. WOETZEL, supra note 74, at xii; see also UN. Study on Punishment of War Criminals, supra note 91 , at 4, para. 10 .

246. See id. at 107-10 (summarizing data regarding thousands of prosecutions undertaken by various countries against persons suspected of committing war crimes and/or crimes against humanity during World War II). Some countries whose domestic law does not provide for prosecution of Nazi war criminals, including the United States, nonetheless actively cooperate with prosecuting nations by extraditing alleged war criminals.

247. See Britain Moving to Allow Trials of Stuspected Nazis, N.Y. Times, May 2, 1991, at A6, col. 1; Delay in Trial of Suspect Accused of War Crimes Has France Astir, N.Y. Times, Oct. 28, 1990, at 16, col. 1; War-Crimes Suspect Seeks to Stay in Canada, N.Y. Times, July 10, 1990, at A2, col. 2; Israel Court Hears Appeal in War Crimes Case, N.Y. Times, May 15, 1990, at A11, col. 1; Argentina to Extradite Ex-SS Man, N.Y. Times, Mar. 25, 1990, at 25, col. 4. 


\section{Punishment: Permissive or Obligatory?}

U.N. actions ratifying the law applied at Nuremberg have, on the whole, maintained that law's emphasis on permissive international jurisdiction. ${ }^{248}$ Despite this focus, the law is fairly interpreted to require, and not merely to authorize, states to punish crimes against humanity when committed in their own jurisdiction. Correctly understood, the emphasis on permissive international jurisdiction signifies the strength of international law's insistence that crimes against humanity must be punished: that principle is so important that it justifies an exception to the bedrock principle of international law-respect for national sovereignty. ${ }^{249}$

Post-Nuremberg developments have underscored the international community's resolve to ensure that crimes against humanity are punished. For example, Principles of International Cooperation in the Detection, Arrest, Extradition, and Punishment of Persons Guilty of War Crimes and Crimes Against Humanity ${ }^{250}$ ("Principles of Cooperation"), adopted by the U.N. General Assembly in 1973, provide that "crimes against humanity, wherever they are committed, shall be subject to investigation and the persons against whom there is evidence that they have committed such crimes shall be subject to tracing, arrest, trial and, if found guilty, to punishment."251 Two conventions adopted since 1968

248. For example, the "Nürnberg Principles" adopted by the General Assembly declare that "[a]ny person who commits an act which constitutes a crime under international law is responsible therefor and liable to punishment," Principle I, Report of the International Law Commission to the General Assembly, 5 U.N. GAOR Supp. (No. 12) at 11, U.N. Doc. A/1316 (1950), and identify crimes against humanity-along with crimes against peace and war crimes-as acts that are "punishable as crimes under international law." Principle VI, id. at 13-14 (emphasis added). Despite this phrasing, an expert on these legal developments has characterized the "Niirnberg Principles" as "confirming that international law required international crimes to be punished ..."2 B. FERENCZ, supra note 66 , at 22.

249. The nature of crimes against humanity made it virtually impossible to address the question of punishing Nazi criminals from any perspective other than that of international enforcement. The U.S. Military Tribunal that presided over the Einsatzgruppen Case reasoned:

Crimes against humanity are acts committed in the course of wholesale and systematic violation of life and liberty. It is to be observed that insofar as international jurisdiction is concerned, the concept of crimes against humanity does not apply to offenses for which the criminal code of any well-ordered state makes adequate provision. They can only come within the purview of this basic code of humanity because the state involved, owing to indifference, impotency or complicity, has been unable or has refused to halt the crimes and punish the criminals.

United States v. Ohlendorf (Case No. 9), IV TRIALS OF WAR CRIMINALS, supra note 68, at 498. Cf. 2 B. FERENCZ, supra note 66, at 23 (asserting that, "[b]y its very nature 'crimes against humanity' seemed to recognize the need for a Court representing all of humankind"). When, however, a democratic government took root in Germany, it assumed responsibility for prosecuting Nazi criminals. Between 1959 and 1981, German courts convicted some 6,000 war criminals. Herz, Denazification and Related Policies, in From DICTATORSHIP TO DEMOCRACY 20 (J. Herz ed. 1982).

250. G.A. Res. 3074, 28 U.N. GAOR Supp. (No. 30) at 79, U.N. Doc. A/9030 (1973).

251. Id., Principle 1. Other resolutions calling on states to cooperate to ensure prosecution and punishment of crimes against humanity include G.A. Res. 2583, 24 U.N. GAOR Supp. (No. 30) at 58, U.N. Doc. A/7630 (1969); G.A. Res. 2712, 25 U.N. GAOR Supp. (No. 28) at 78-79, U.N. Doc. A/8028 (1970); and G.A. Res. 2840, 26 U.N. GAOR Supp. (No. 29) at 88, U.N. Doc. A/8429 (197I). A resolution adopted in 1967 provided that states would not grant asylum to any person who was seriously suspected of committing war crimes, crimes against peace or crimes against humanity. Declaration on Territorial Asylum, G.A. Res. 2312, 22 U.N. GAOR Supp. (No. 16) at 81, U.N. Doc. A/6716 (1967). 
provide that crimes against humanity shall not be subject to any statute of limitations. ${ }^{252}$

Preeminent values underlying the international legal order are best served if a government whose predecessors committed crimes against humanity assumes responsibility for punishment. Prosecution under these circumstances reconciles international law's insistence on the one hand that crimes against humanity must not escape punishment, and its concern on the other hand to respect national sovereignty. The Principles of Cooperation exemplify this approach. Principle 2 provides: "Every State has the right to try its own nationals for . . . crimes against humanity," and Principle 5 provides: "Persons against whom there is evidence that they have committed ... crimes against humanity shall be subject to trial and, if found guilty, to punishment, as a general rule in the countries in which they committed those crimes. In that connexion, States shall co-operate on questions of extraditing such persons."

\section{Enduring Significance of Crimes Against Humanity}

While some aspects of the law relating to crimes against humanity remain ambiguous, that law's core principle is both clear and widely accepted: atrocious acts committed on a mass scale against racial, religious, or political groups must be punished. To some extent, the significance of this law as a distinct source of obligation has been eclipsed by the development of more expansive duties to punish atrocious human rights violations. States Parties to the conventions examined in Section II.C are generally required to punish torture, illegal killings, and disappearances, a broader duty than that imposed by the customary law of crimes against humanity. And customary law is now breached by a state's complete failure to punish repeated or notorious instances of these offenses, regardless of the animus of the violations. ${ }^{253}$ Further, customary law relating to genocide imposes a duty to punish conduct that overlaps substantially with crimes against humanity. ${ }^{254}$

But if the law of crimes against humanity is increasingly redundant of other law, it has not become superfluous. In the absence of effective enforcement machinery, international law's power to induce compliance with its prescriptions turns on the strength of the norms themselves. ${ }^{255}$ It is, perhaps, in this respect

252. See supra note 240. Although the Convention on the Non-Applicability of Statutory Limitations to War Crimes and Crimes Against Humanity, supra note 238 , does not explicitly provide that States Parties must prosecute crimes against humanity, it was adopted to fill what the drafters perceived as a gap in international law which, in their view, already required punishment but failed to make clear that no statute of limitations should apply. See Miller, supra note 238, at 477 . In the Barbie case, the French Court of Cassation found that the non-applicability of statutes of limitations to crimes against humanity is a rule of customary law. Barbie, 78 I.L.R. 132, 135 (1988) (Judgment of Jan. 26, 1984, Cass. Crim., Fr.).

253. See supra text accompanying notes 198-99.

254. See supra notes $216,228$.

255. See Orentlicher, The Power of an Idea: The Impact of United States Human Rights Policy, 1 TRANSNAT'L L. \& CONTEMP. PROB. 43, 65 (1991):Reisman, Sanctions and Enforcement, in INTERNATIONAL 
that the enduring significance of crimes against humanity is best understood. The law proscribing crimes against humanity has commanded a uniquely powerful commitment by the world community, which has resolved emphatically that it will not countenance impunity for massive atrocities against persecuted groups.

\section{APPLicAtion OF GeNERAL RULE TO TRANSITIONAL SOCIETIES}

If international law generally requires states to punish serious violations of physical integrity, ${ }^{256}$ must a successor government attempt to prosecute every such violation committed with impunity during a recent dictatorship? Or does international law provide a basis for "mitigating" the duty in light of the peculiar constraints prevailing in transitional societies?

In addressing these questions, it is important to begin by making clear what is not at issue. First, the fact that a democratically elected government succeeds a repressive regime has no bearing on the state's international obligations. It is well-established that a change in government does not relieve a state of its duties under international law. ${ }^{257}$ Accordingly, if an outgoing government failed to discharge its duty to punish atrocious crimes, its successor is generally bound to fulfill the obligation.

Second, that prosecutions may be inexpedient politically is no excuse for a government's failure to discharge its legal obligations. International law does not, of course, require states to take action that poses a serious threat to vital national interests. ${ }^{258}$ But a state cannot evade its duty to punish atrocious crimes merely to appease disaffected military forces or to promote national reconciliation. ${ }^{259}$ However desirable the objectives, the government must find other means to achieve them. Ratification of an amnesty law through some form of democratic procedure ${ }^{260}$ would not alter this conclusion; nations cannot

LAW ESSAYS: A SUPPLEMENT TO INTERNATIONAL LAW IN CONTEMPORARY PERSPECTIVE 403 (M. McDougal \& W. M. Reisman eds. 1981).

256. The phrase "serious violations of physical integrity" is used here to refer to torture, disappearances and illegal killings; it is not intended to cover other violations of physical integrity proscribed by human rights conventions, such as subjecting detainees to inhumane conditions.

257. See Velásquez Rodríguez Case, Inter-Am. Ct. H.R. (ser. C) No. 4, para. 184 (1988) (judgment);

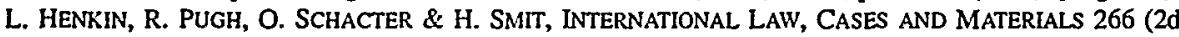
ed. 1987).

258. See infra Section B.

259. See supra text accompanying notes $25-26,38$.

260. José Zalaquett urges that a policy addressing abuses of the past-including an amnesty-“"must be approved in a manner that reflects the will of the people," such as by popular referendum. Zalaquett, supra note 8 , at 34 . Others have challenged this view, asserting that only the victim of a violation can forgive her tormentor. See L. WESCHLER, supra note 11, at 244. Zalaquett's suggestion is particularly troubling in light of the fact that victims of human rights violations are usually members of politically weak social groups. Surely a political majority should not be allowed to determine whether these victims' rights will be protected by law enforcement. $C f$. L. TRIBE, ABORTION: THE CLASH OF ABSOLUTES 80 (1990) ("The whole point of an independent judiciary is to be 'antidemocratic,' to preserve from transient majorities those 
extinguish their international obligations by enacting inconsistent domestic law. ${ }^{261}$

\section{A. Mitigating the Burden}

Somewhat more difficult issues are raised by the question whether international law can accommodate the peculiar constraints faced by nations that have recently emerged from a protracted period of lawlessness. In a country like Argentina, where some 9,000 persons are estimated to have disappeared during the military juntas' "dirty war against subversion," 262 a requirement that the government attempt to prosecute everyone who may be criminally liable could place impossible demands on the judiciary. ${ }^{263}$ Even a well-functioning judicial system would be incapable of discharging such a burden; ${ }^{264}$ much less can this be expected following the wholesale collapse of judicial process.

Further, the experiences of countries that have recently emerged from dictatorship suggest that post-transition trials may provoke political instability if the prosecutions are not confined within principled limits. A particularly instructive example is the experience of Argentina, where the most ambitious effort to prosecute past violations among countries swept by the recent tide of democratic transitions was undertaken by the government of Raúl Alfonsín. His government, which entered office in December 1983, prosecuted nine former junta members and several other officers for abuses committed during Argentina's "dirty war against subversion" in the late 1970's and early '80's. But military uprisings provoked largely by efforts to prosecute active-duty, midlevel officers led the government to retreat from further prosecutions; ultimate-

human rights ... to which our legal and political system is committed. Without this role there would be nothing to stop a bare majority of our citizens from deciding tomorrow that the minority should be enslaved ....") (emphasis in original).

261. See Montealegre, supra note 35 , at 50 ("Only the community of nations that created [a crime defined by international law] can abolish it."); see also sources cited supra note 62 .

262. NUNCA MAS: THE REPORT OF THE ARGENTINE NATIONAL COMMISSION ON THE DISAPPEARED 10 (1986).

263. Some experts on Argentina believe, however, that evidentiary constraints could have confined the number of human rights trials to a manageable level even without laws limiting the scope of prosecutions. E.g., Interview with Professor Alejandro Garro, New York City (July 31, 1990).

264. It has been observed that a key reason why some continental European countries have been able to maintain a system of mandatory prosecution for serious offenses is that their criminal justice systems are capable of processing the cases. See Damaska, The Reality of Prosecutorial Discretion: Comments on a German Monograph, 29 AM. J. CoMP. L. 119, 122-24 (1981); Langbein, Controlling Prosecutorial Discretion in Germany, 41 U. CHI. L. REV. 439, 466-67 (1974) [hereinafter Langbein, Controlling Discretion]. In contrast, prosecutorial discretion is thought to have developed in the United States in large part because the combined impact of high crime rates and extensive procedural rights makes it impossible for U.S. courts to process every serious crime that is potentially prosecutable. See Langbein, supra, at 44546; Langbein, Understanding the Short History of Plea Bargaining, 13 LAW AND SOC'Y 261, 265, 267 (Winter 1979). As these analyses suggest, a prerequisite of any law requiring prosecution of particular offenses is that the national judiciary must be capable of handling the burden imposed by that law. 
ly, it secured passage of two laws that effectively amnestied most violations by junior and mid-level officers. ${ }^{265}$

By all accounts, a key flaw in implementation of Alfonsín's prosecution program was its protracted nature. ${ }^{266}$ The prosecutions extended substantially longer than the architects of the program had anticipated. ${ }^{267}$ While there was strong public support for prosecutions at the outset of Alfonsín's presidency, this waned as time elapsed and other issues-in particular, those pertaining to Argentina's disintegrating economy-rose to greater public prominence. ${ }^{268}$ Simultaneously, the military, which at the outset of Alfonsin's term was weakened by its recent humiliation in the Falklands/Malvinas war, gradually recomposed itself and become a more viable threat to the Alfonsín government. ${ }^{269}$ For a variety of reasons, then, it became increasingly clear that the nation could not sustain indefinitely drawn-out prosecutions. ${ }^{270}$

The Alfonsín government also faced growing hostility from military factions as the scope of prosecutions broadened beyond the top commanders. Although

265. In December 1986, President Alfonsín secured enactment of the "full stop" law (ley de punto final), Law No. 23492, December 24, 1986, which set a 60-day limit on the initiation of new criminal complaints relating to human rights violations committed during the "dirty war." Although the law was designed to bring a close to prosecutions of military officers, it instead drew a flood of new complaints filed before the deadline. This stoked military discontent, which President Alfonsín sought to quell by securing passage of the "due obedience" law (ley de obediencia debida), Law No. 23521, June 4, 1987. That law established an irrebuttable presumption that military officials, with the exception of certain commanders, committed human rights abuses under coercion, and rendered them immune from prosecution on this basis. The Alfonsín government's unseemly retreat detracted from its achievement in bringing past junta members to account, and arguably emboldened military rebels to launch further revolts. See Neier, supra note 22, at 34. In consequence, even those who endorse the general outcome of Alfonsín's prosecutions-convicting high-level officers without completing more wide-ranging prosecutions-believe that the manner in which the result was achieved was detrimental. See id.; AMERICAS WATCH ARGENTINA REPORT, supra note 214, at 83 .

266. Several developments caused delays that the Alfonsín government did not anticipate. Substantial time was lost when the Supreme Council of the Armed Forces, which had original jurisdiction over the trials of military officers, resisted judging them. See Garro \& Dahl, supra note 9, at 319-20. Pursuant to legislation enacted at the instance of the Alfonsin administration, the cases were removed to a civilian court. In the meantime, the better part of a year was lost due to the Supreme Council's recalcitrance. Further, the civilian courts that had jurisdiction over cases filed by private parties tended to move slowly on those cases until prodded into swifter action by enactment of the "full stop" law. See supra note 265.

267. See Malamud-Goti, supra note 10 , at 74 .

268. This phenomenon is common to many countries in which an elected government succeeds a repressive one. Elsewhere I have argued that the most auspicious time for Philippine President Corazon Aquino to institute prosecutions of military personnel for crimes committed during the tenure of her predecessor, Ferdinand Marcos, was in the months immediately following Aquino's inauguration. During that period Aquino had a strong mandate to redress the rights violations of the Marcos period, and enjoyed greater power over the military than she would ever again possess. D. Orentlicher, supra note 37 . Telford Taylor, the chief United States prosecutor of war criminals at Nuremberg following the Allied Powers' joint prosecution of Major War Criminals, similarly found that public support for prosecutions waned as time passed and international concerns shifted elsewhere. See TAYLOR REPORT, stipra note 32, at 105.

269. See Malamud-Goti, supra note 10 , at 74.

270. Various efforts by the Alfonsín administration to restrict the scope of prosecutions were thwarted by other branches of government. For example, a bili prepared by the Alfonsín government establishing the basis of prosecutions was amended, at the instance of a Senator from a small provincial party, in a manner that opened the possibility of prosecuting a relatively large number of soldiers. For further discussion of this subject, see L. Moreno Ocampo, supra note $31, \S 1.3$. 
many officers had accepted prosecution of the commanders most responsible for implementing the "dirty war," the military grew restive when prosecutions began to sweep more broadly, in large part because this was thought to tarnish the military institutionally. ${ }^{271}$

Prosecutions in the mid-1970's of Greek military police for torture committed during the preceding period of military rule provide a contrasting example. From the outset, the Karamanlis government made clear that prosecutions would not be indefinite. It set a six-month deadline on the filing of private prosecutions against high-level officials, and a three-month deadline for suits against other officials. ${ }^{272}$ Although the prosecutions in Greece provoked military discontent, the response was far less destabilizing than the military backlash in Argentina. ${ }^{273}$

The contrasting experiences of Argentina and Greece suggest that the demands of justice and political stability are best reconciled through a program of prosecutions that has defined limits. To the extent that the purpose of prosecutions is to vindicate the authority of the law and deter repetition of recent crimes, ${ }^{274}$ it is not necessary that a transitional government prosecute all who participated in a previous system of violations. These and other objectives served by post-transition prosecutions can be accomplished with exemplary trials, ${ }^{275}$ provided the criteria used to select defendants do not vitiate the justifying aims of prosecutions by, for example, cynically targeting scapegoats. Once the chief aims of criminal law enforcement are achieved, further

271. See Malamud-Goti, supra note 10, at 73-74; Neier, supra note 22, at 34. Neier speculates that, "if the prosecutions had been limited to [junta members], the military uprisings against the Alfonsin government might never have taken place." $I d$.

272. All of the prosecutions for human rights violations that ensued were the result of private initiative.

273. The Karamanlis government was threatened by four conspiracies to re-establish military government. See Danopoulos, Beating a Hasty Retreat: The Greek Military Withdraws from Power, in THE DECLINE OF MILITARY REGIMES 246 (C. Danopoulos ed. 1988). The Karamanlis government was more successful than the Alfonsin government in establishing control over the military. Although various circumstantial factors, such as the military's preoccupation with Turkish aggression, reduced the threat of a successful military coup, the Greek military's ultimate acceptance of civilian authority is also a tribute to the effectiveness of the Karamanlis government's policies. While responding to legitimate military needs by increasing defense appropriations and maintaining generous benefits, such as medical care and housing for military officers, the Karamanlis government constantly asserted the principle of civilian supremacy, and made concerted efforts to persuade military officers of the merits of democracy. See id. at 249. For a thoughtful analysis of these issues, see Keith Syrett, Torture Trials and the Transition to Democracy in Greece from 1974 (1989) (unpublished manuscript on file with author).

274. See supra text accompanying notes 9-15.

275. As Professor Packer has observed, the social institution of criminal punishment achieves a deterrent effect by establishing a general warning that violation of a law carries the threat of punishment, coupled with the "occasional spectacle of its actual infliction." H. PACKER, supra note 12, at 42 . Thus, while a "minimum of punishment [is] needed to keep the threat credible," id. at 63 , it is not necessary to prosecute every violation to deter criminal conduct. See also K. DAVIS, supra note 15, at 168 ("The proper objective of an enforcement program is not the unrealistic one of penalizing all violators but the practical one of penalizing enough violators to induce a satisfactory degree of compliance."). 
prosecutions have "diminishing returns" and may reverse progress toward consolidating a democratic transition. ${ }^{276}$

\section{Application of Customary International Law}

The duty to punish human rights crimes imposed by customary law can readily accommodate the constraints faced by transitional societies. Applying the Restatement rule, customary law would be violated by complete impunity for repeated or notorious instances of torture, extra-legal executions, and disappearances, ${ }^{277}$ but would not require prosecution of every person who committed such an offense. Prosecution of those who were most responsible for designing and implementing a system of human rights atrocities or for especially notorious crimes that were emblematic of past violations would seemingly discharge governments' customary-law obligation not to condone or encourage such violations, ${ }^{278}$ provided the criteria used to select potential defendants did not appear to condone or tolerate past abuses.

\section{Application of Comprehensive Human Rights Conventions}

More complex issues are raised by the question whether a government of a state that has ratified the International Covenant, the European Convention, or the American Convention must attempt to prosecute all serious violations of the right to physical integrity committed, following the convention's entry into force for the state, by or with the acquiescence of a previous regime. Decisions interpreting these conventions include some indications that States Parties are in general expected to investigate every violation of the rights to life, freedom from torture, and freedom from involuntary disappearances, and to prosecute those who are responsible. ${ }^{279} \mathrm{~A}$ rigid application of the general rule that a state's international obligations persist despite a change in government $^{250}$ might, then, require successor governments to prosecute virtually

276. Malamud-Goti, supra note 9, at 13-14. Jose Zalaquett suggests that a circumscribed program of prosecutions might afford transitional governments an opportunity to offer inducements, such as immunity or leniency in exchange for military testimony, that could both improve the prospects of establishing responsibility and diminish the military's propensity to "close ranks." Zalaquett, supra note 8, at 57; Zalaquett, From Dictatorship to Democracy: Kicking Out the Generals Is Only the First Chapter, THE NEW REPUBLIC 20 (Dec. 16, 1985).

277. See supra notes $198-99$ and accompanying text.

278. Id.

279. For example, in the Velásquez Rodriguez Case the Inter-American Court repeatedly asserts that a State Party to the American Convention must investigate and punish "any" and "every" violation of the rights protected by the convention. See supra note 169 and accompanying text. In $X$ and $Y v$. Netherlands, the European Court found the Dutch government responsible for violating the European Convention because a gap in Dutch law prevented the applicant from initiating a criminal complaint against her rapist, even though Dutch law generally provided for such a procedure and, more generally, for prosecution of rape. See supra note 183 and text accompanying notes $182-85$.

280. See supra text accompanying note 257 . 
every violation of those three rights that has not yet been punished. ${ }^{281}$ Yet, for reasons suggested above, such a requirement could produce untenable results.

Pursuant to general canons of construction, the comprehensive treaties should be interpreted in a manner that avoids imposing impossible obligations or duties whose discharge would prove harmful. ${ }^{282}$ A functional analysis ${ }^{283}$ of the general rule requiring prosecution of torture, extra-legal killings, and disappearances provides a principled basis for such an interpretation. ${ }^{284}$

As noted earlier, the duty to punish these three crimes is squarely grounded on a deterrence rationale. ${ }^{285}$ Believing criminal sanctions to be the most effective means of securing rights deemed of paramount importance, bodies such as the Human Rights Committee and the Inter-American Commission have found investigation leading to punishment to be the most appropriate response to violations of those rights. ${ }^{286}$ The deterrence rationale supporting their decisions generally favors prosecution of each violation, since criminal laws are

281. In the Velásquez Rodriguez Case the Inter-American Court suggested that the American Convention is not necessarily violated by a State Party's failure to punish a violation: "In certain circumstances, it may be difficult to investigate acts that violate an individual's rights. The duty to investigate, like the duty to prevent, is not breached merely because the investigation does not produce a satisfactory result. Nevertheless, it must be undertaken in a serious manner and not as a mere formality preordained to be ineffective." Velásquez Rođríguez Case, Inter-Am. Ct. H.R. (ser. C) No. 4, para. 177 (1988) (judgment). See also id. at para. 181 (alluding to "the hypothetical case that those individually responsible for crimes ... cannot be legally punished under certain circumstances"). The Court presumably intended to acknowledge that legitimate factors, such as insufficiency of evidence, may justify a failure to prosecute, provided an investigation was undertaken in good faith.

282. $C f$. [1978] 2 Y.B. INT'L L. COMM'N (pt. 1), at 75, para. 33, U.N. Doc. A/CN.4/315 (1977) (quoting Schwarzenberger's view that treaty obligations "are likely to be interpreted in a manner which circumscribes them so as to exclude situations of both absolute and relative impossibility from the very scope of such duties"); $i d$. at 133 (quoting assertion by Professor Alfred von Verdross of principle that "international duties must not be taken so far as to result in self-destruction").

283. By "functional analysis," I mean an analysis of the application of a general rule of law to a particular situation in light of the rationale supporting the general rule.

284. A functional analysis may be more appropriate with respect to the duty to institute criminal proceedings imposed by comprehensive human rights treaties than with respect to the duty to punish explicitly established by the Genocide Convention and the Convention Against Torture. In the former instance, the duty has arisen as a matter of interpretation of States Parties' explicit duty to ensure several enumerated rights; the duty to punish exists because it is deemed instrumental to the effective enjoyment of those rights. Accordingly, a greater degree of flexibility may be justified in identifying the scope of that duty than would be appropriate with respect to a duty to punish that is explicitly set forth in a convention. Still, accommodation of the constraints faced by transitional governments may be possible under the torture and genocide conventions on the basis that unforeseen developments-such as the debilitating effects of a protracted period of lawlessness-render full compliance impossible. $C f$. Vienna Convention, supra note 62, arts. 61 (impossibility of performance) and 62 (unforeseen, fundamental change of circumstances). Application of these excuses for non-compliance is problematic, however. Under the Vienna Convention on the Law of Treaties, the excuses cannot be invoked by a State Party that brought about the conditions of impossibility or the fundamental change in circumstances by breaching an obligation owed to another State Party under the treaty or pursuant to another source of international duty. Id. For analysis of this issue in another context, see infra text accompanying notes 333-45.

285. This is implicit in the fact that the duty to prosecute is consistently identified with, and based upon, States Parties" obligation to "ensure" or "secure" enumerated rights. And, as the European Court explicitly stated in its judgment in $X$ and $Y v$. Netherlands, only criminal punishment is an adequate deterrent to violations of rights that are of crucial importance. See supra text accompanying note 185 .

286. See supra text accompanying notes 161-62, 176-77. 
most likely to deter potential violators when the threat of punishment is as nearly certain as possible. For this reason, the conventions can fairly be interpreted to require successor governments to investigate and seek to punish each violation committed on their own watch. Similarly, the prior government should have made good faith efforts to prosecute each violation committed during its tenure. But the same logic would not compel prosecution of all offenders once massive violations have occurred with impunity. In these circumstances, full enforcement is neither capable of preventing the crimes that have already occurred, nor necessary effectively to deter potential lawbreakers of the future. A bounded program of exemplary punishment could have a significant deterrent effect, and thus achieve the aim justifying the general duty to punish atrocious crimes.

In contrast, a failure to punish any of the past violations would thwart the deterrence objective underlying the general duty to punish. If a government established complete impunity for atrocious crimes committed on a sweeping scale, its action would, as the Restatement reasoned, have the effect of tolerating or condoning the past violations and thereby encouraging similar ones. ${ }^{287}$ This result is plainly incompatible with states' convention-based duty to undertake affirmative measures to prevent violations of physical integrity. ${ }^{288}$

While limitations on prosecutions may be compatible with states' international obligations, a policy that exonerates large numbers of persons who committed atrocious crimes offends common standards of justice and diminishes respect for the law. The best means of accommodating competing values might be to combine a finite program of prosecutions with legislation establishing a statute of limitations governing further prosecutions. ${ }^{289}$ Such legislation ${ }^{290}$ would minimize the destabilizing effects of trials ${ }^{291}$ while affirming the rule of law.

\section{Selection Criteria}

The possibility of limited prosecutions raises the difficult issue of appropriate criteria for selecting defendants. Although selective prosecution is accepted

287. See supra text accompanying notes 198-99; see also supra text accompanying notes 12-13.

288. A similar conclusion follows from application of the doctrine pacta sunt servanda, an integral element of which is the principle of good faith performance. See Vienna Convention, supra note 62, art. 26. Wholesale impunity for a system of atrocious crimes surely violates States Parties' commitment to perform their duties under the comprehensive human rights conventions in good faith.

289. The distinction drawn here has particular relevance for countries in which both the government and private parties can initiate criminal proceedings, but may also be pertinent to countries whare only the government can institute prosecutions. In the latter, the "selective prosecutions" referred to would be pursued as a matter of high governmental priority (in Argentina, prosecutions of former junta leaders were ordered by presidential decree), while additional prosecutions would be left to the initiative of individual prosecutors' offices.

290. Any time limit established by law should be reasonable. See supra note 126.

291. See supra text accompanying notes 265-73. 
in principle in virtually all legal systems, ${ }^{292}$ its exercise poses the risk of arbitrariness ${ }^{293}$ and may threaten the principle of equality before the law. ${ }^{294}$

These risks are minimized, however, if the criteria used to select defendants reflect appropriate distinctions based upon degrees of culpability. ${ }^{295}$ Such distinctions are drawn in every country's criminal law. ${ }^{296}$ They are reflected both in gradations of punishment prescribed by penal law and in enforcement patterns, which typically reflect a priority on prosecuting persons responsible for the most serious offenses. Moreover, in cases involving criminal syndicates, greatest priority is generally placed upon convicting leaders. ${ }^{297}$ Accordingly, prosecutions by a transitional government that focused on those most responsible for designing and implementing a past system of rights violations ${ }^{298}$ or

292. Even legal systems that require prosecution of certain offenses generally allow prosecutors to exercise discretion with respect to less serious offenses. See Damaska, supra note 264, at 122; Goldstein \& Marcus, The Myth of Judicial Supervision in Three "Inquisitorial" Systems: France, Italy, and Germany, 87 YALE L.J. 240, 250 (1977); Langbein, Controlling Discretion, supra note 264, at 450-451.

293. See H. PACKER, supra note 12, at 290. See generally K. DAVIS, supra note 15 . An effort to prosecute virtually everyone who may be liable for crimes committed during a past program of repression also can generate arbitrary enforcement practices. For an account of problems of this kind encountered in the denazification program in post-war Germany, see Herz, supra note 249.

294. The right to equality before the law is enshrined in Article 7 of the Univeral Declaration of Human Rights, supra note 84, and in all of the comprehensive human rights conventions. International Covenant, supra note 54, art. 14; Banjul Charter, supra note 131, art. 3; American Convention, supra note 92, art. 24; European Convention, supra note 34, art. 14.

295. Moreover the appearance of arbitrariness is lessened if it is clear that a failure to attempt full enforcement is based in large part on resource constraints. $C f$. H. PACKER, supra note 12, at 291 (when enforcement of a criminal law is "taken seriously but resources are inadequate to provide anything like full enforcement, the discrimination [in enforcement among violators] becomes less flagrant but remains objectionable").

296. Whether justified on retributivist, utilitarian or other grounds, all legal systems assign more serious penalties to more serious crimes. See H.L.A. HART, PUNISHMENT AND RESPONSIBILITY chs. 1, 7 (1968); C. BECCARIA, AN ESSAY ON CRIMES AND PUNISHMENT, chs. VII-VI, XXXVII (1872); J. BENTHAM, PRINCIPLES OF MORALS AND LEGISLATION, chs. XIV-XVI (1823). The seriousness of a crime is generally thought to depend upon both the harm it produces and the culpability of the offender. See von Hirsh, Proportionality in the Philosophy of Punishment: From "Why Punish?" to "How Much?," 1 CRM. L. FORUM 259, 266 (1990).

297. This priority underlies the common practice in the United States of allowing low-level participants in organized crime to plead guilty to a relatively minor offense or to receive immunity in exchange for testimony that will help convict their superiors. $C f$. H. ABADINSKY, SOCIAL SERVICE IN CRIMiNAL JUSTICE 95 (1979) (factors determining whether charges will be brought include whether potential defendant would be "valuable as a witness in another trial or against parties involved with him"); American Bar Association Project on Standards for Criminal Justice, THE PROSECUTION FUNCTION AND THE DEFENSE FUNCTION, § 3.9(b)(vii) (1971) (in exercising discretion in the charging function, a prosecutor may properly consider the "cooperation of the accused in the apprehension or conviction of others"); President's Commission on Law Enforcement and Administration of Justice, THE CHALLENGE OF CRIME IN A FREE SOCIETY 503 (1968) (addressing narcotics laws, asserting, "The objectives of law enforcement are to reach the highest possible sources of drug supply .....”).

298. Essentially this type of consideration, coupled with such other concerns as the availability of evidence, guided the Allied nations' selection of defendants prosecuted at Nuremberg. See TAYLOR REPORT, supra note 32, at 73-85. A study prepared by a U.N. Special Rapporteur suggests that amnesties should not be available for torture, involuntary disappearances and summary executions committed in a systematic fashion, and adds: "At the very least the authority granting amnesty, drawing on the legal theory of conspiracy, can exclude the instigators and higher officials from amnesty, particularly those in charge of agencies responsible for organizing and carrying out . . . 'administrative practices'." U.N. Study on Amnesty Laws, supra note 26, at 13, para. 63. 
on the most notorious crimes ${ }^{299}$ would best comport with common standards of justice.

Although a thorough consideration of appropriate selection criteria is beyond the scope of this Article, several negative criteria should be noted. First, consistent with universally accepted principles of law, individuals should never be exonerated or exempted from prosecution for grave human rights violations on the ground that they were "following orders," although this circumstance can be considered in mitigation of punishment. ${ }^{300}$ While a prosecution program may in fact allow low-level officers and soldiers to escape punishment, that result should never be achieved by endorsing a "superior orders" justification for committing atrocious crimes. ${ }^{301}$

Second, as suggested earlier, a government should not cynically prosecute a group of scapegoats. This might happen, for example, if prosecutions were directed against only low-level participants in a system of past atrocities or if patently political considerations infected the determination of defendants. ${ }^{302}$ Such prosecutions would vitiate the authority of the law and thereby deprive the prosecutions of their deterrent power.

299. The U.N. Special Rapporteur on Chile has urged Chilean authorities to make especially concerted efforts to prosecute several exemplary cases that "have shocked Chilean society." Report prepared by Professor Fernando Volio Jiménez (Costa Rica), Special Rapporteur on the simation of human rights in Chile, in accordance with paragraph 12 of Commission on Human Rights resolution 1987160 of 12 March 19S7, U.N. Doc. A/42/556, para. 105 (1987); see also id., para. 126; Report on the question of human rights in Chile submitted by Mr. Fernando Volio Jiménez (Costa Rica), Special Rapporteur, pursuant to the mandate conferred under resolution $1988 / 78$ of the Commission on Human Rights, 45 U.N. ESCOR Comm'n on Hum. Rts., paras. 54, 63, U.N. Doc. E/CN.4/1989/7.

300. The Nuremberg Charter provided that the fact that a defendant "acted pursuant to order of his Government or of a superior shall not free him from responsibility, but may be considered in mitigation of punishment ...." Nuremberg Charter, supra note 83, art. 8. This principle was subsequently ratified by the United Nations General Assembly, Principle IV, Report of the International Law Commission to the General Assembly, 5 U.N. GAOR Supp. (No. 12) at 11-14, U.N. Doc. A/1316 (1950), and has been absorbed into virtually all major legal systems. The principle has been incorporated, as well, in numerous international instruments. See, e.g., Convention Against Torture, supra note 67, art. 2(3); Inter-American Convention to Prevent and Punish Torture, supra note 92, art. 4; Draft Inter-American Convention on Forced Disappearances, supra note 210, art. 9; Code of Conduct for Law Enforcement Officials, art. 5, G.A. Res. 34/169, Annex (1979); Draft Declaration on Disappearances, supra note 208, art. 6(1); Principles on the Effective Prevention and Investigation of Extra-legal, Arbitrary and Summary Executions, supra note 211, Principle 19 (each asserting that acting pursuant to superior orders is no defense to proscribed conduct).

301. The "due obedience" law enacted in Argentina, see supra note 265, has appropriately been criticized because it contravenes the Nuremberg principle regarding the invalidity of a superior orders defense. See, e.g., Rogers, supra note 5, at 274; see also AMERICAS WATCH ARGENTINA REPORT, supra note 214, at 82 ("due obedience" law contravenes Argentina's obligations under Convention Against Torture, which bars superior orders defense).

302. An apparent example of the latter is the program of prosecutions undertaken by the Romanian government in the aftermath of the December 1989 uprising against Nicolae Ceausescu. Trials of former Ceausescu aides undertaken shortly after the revolution focused on the defendants' conduct during the five days of the revolution itself, and did not cover abuses during the previous twenty-five years of Ceausescu rule. This narrow focus apparently allowed former members of the Ceausescu regime who were also members of the successor government to escape accountability for their participation in past abuses. See HELSINKI WATCH, TRIALS IN ROMANIA 1 (March 1990). 


\section{Amnesty vs. Pardon}

Some analysts ${ }^{303}$ have suggested that a pardon that spares a convicted human rights offender from serving his sentence or from completing the full term is less objectionable than an amnesty that forecloses prosecutions, consigning past crimes to oblivion. ${ }^{304}$ This claim has intuitive appeal: In many countries, democracy has been secured with the blood of men and women whose suffering an amnesty would entomb forever in a grave of silence and denial. A pardon, in contrast, would leave the judgment of guilt intact.

But if the moral distinction between amnesty and pardon seems clear, the legal distinction is less so. On the one hand, the language of two conventions examined in Part II seems to support the claim that a post-conviction pardon might be permissible where an amnesty is not. As noted earlier, the Convention Against Torture requires States Parties to "submit" cases involving allegations of torture to the "competent authorities for the purpose of prosecution"; it does not explicitly require that a prosecution take place, ${ }^{305}$ let alone that punishment be imposed and served. ${ }^{306}$ And while the Genocide Convention explicitly provides that persons who commit genocide "shall be punished," a criminal conviction conceivably might satisfy this duty. For, as one writer has observed, " $[t]$ he essence of punishment for moral delinquency lies in the criminal conviction itself." 307 Similar reasoning would apply to the comprehensive human rights conventions that have been interpreted to require States Parties to investigate grave abuses and to "hold responsible" or "bring to justice" those who are guilty. Even when international law establishes a duty to prosecute particular offenses, it generally leaves the determination of penalties to the discretion of national governments. ${ }^{308}$

Still, it would be a mistake to conclude that international law is indifferent to the use of pardons. The conventions on genocide and torture evince concern that appropriately severe penalties be imposed on persons convicted of those crimes: Article V of the Genocide Convention requires Contracting Parties to enact legislation providing "effective penalties for persons guilty of genocide," while Article 4 of the Convention Against Torture requires States Parties to make acts of torture "punishable by appropriate penalties which take into account their grave nature." Although these conventions do not prescribe

303. E.g., Rogers, supra note 5, at 304.

304. See supra note 14.

305. See J. BURGERS \& H. DANELIUS, sipra note 92, at 138.

306. The drafters presumably recognized that there might be legitimate reasons to terminate an investigation without proceeding to trial, such as lack of necessary evidence. They also apparently sought to respect the independence of national courts and the procedural rights of defendants by avoiding language that suggested that a particular outcome of prosecutions was required.

307. Gardner, Bailey v. Richardson and the Constitution of the United States, 33 B.U.L. REv. 176, 193 (1953); see also H. PACKER, supra note 12, at 36 (identifying formal judgment of guilt as the crucial element of punishment).

308. See Dinstein, supra note 57, at 224. 
specific penalties, their manifest intent is that persons convicted of genocide and torture serve sentences that reflect the gravity of the offenses. ${ }^{309}$ And the duty to punish grave violations of comprehensive human rights treaties surely would be breached by a State Party's consistent failure to impose punishment commensurate with the gravity of the crimes. ${ }^{310}$

309. Commenting on Article V of the Genocide Convention, one writer has asserted that "insufficient .. p penalties may well be construed as representing a violation of this obligation." N. ROBINSON, supra note 106, at 77. In practice, states have tended to prescribe severe penalties for genocide. See UN. Study on Punishment of War Criminals, supra note 91, at 78, paras. 264-65; id. at 106, para. 383. In the view of two men who participated in drafting the Convention Against Torture, Article 4 "means that torture must be punishable by severe penalties." J. BURGERS \& H. DANELIUS, supra note 92 , at 129 . Messrs. Burgers and Danelius note that

it was not possible to indicate in the Convention any particular penalty which should be applied, such as imprisonment above a certain minimum [since] the practice with regard to criminal sanctions differs very much from country to country, and the severity of a penalty must therefore be assersed in relation to the severity of the sanctions which are generally applied in a particular country. ... In applying article 4 it seems reasonable to require, however, that the punishment for torture should be close to the penalties applied to the most serious offences under the domestic legal system.

Id. Whatever latitude these provisions allow, both would be violated by pardons that spared torturers or persons responsible for genocide from serving any sentence or that rendered their punishment patently inadequate.

During drafting of the International Covenant on Civil and Political Rights, delegates repeatedly insisted that a draft provision that entitled criminal defendants to benefit from changes in law establishing lighter penalties should not apply to persons who committed genocide or other crimes against humanity; several delegates stressed, in particular, that such criminals should not be allowed to benefit from an amnesty. See, e.g., 15 U.N. GAOR C.3 at 131, paras. 20, 24, U.N. Doc. A/C.3/SR.1007 (1960) (remarks of delegate from the United Kingdom).

310. This view is supported by the judgment in the Velasquez Radriguez Case, in which the InterAmerican Court stated that States Parties must impose "appropriate punishment" for violations of the American Convention. See supra text accompanying note 167. The Inter-American Convention to Prevent and Punish Torture, supra note 92, requires States Parties to make acts of torture "punishable by severe penalties that take into account their serious nature." Id., art. 6. States could commit the customary law violation of "denial of justice" to aliens not only by failing to prosecute and punish persons who committed crimes against aliens, but also by "prosecution and light punishment; prosecution, punishment and pardon; [and] prosecution and release. ..." In re Janes (U.S. v. Mex.), 4 REP. INT'L ARB. AWARDS 32, 90 (1926). A number of United Nations documents support the view that appropriately severe penalties are necessary to ensure the right to physical integrity. See,e.g., Principles on the Effective Prevention and Investigation of Extra-legal, Arbitrary and Summary Executions, supra note 211, Principle 1 (extra-legal executions shall be punishable by "appropriate penalties which take into account the seriousness of such offences"); Draft Declaration on Disappearances, supra note 208 , art. 4 (each state shall ensure that all forms of participaion in disappearances "are specific crimes of the gravest kind under its criminal law"); Report on the question of human rights in Chile submitted by Mr. Fernando Volio Jiménez (Costa Rica), Special Rapporteur, pursuant to the mandate conferred under resolution 1989/62 of the Commission on Human Rights, 46 U.N. ESCOR Comm'n on Hum. Rts. at 20, para. 23, U.N. Doc. E/CN.4/1990/5 (although conviction was rendered in case involving the burning of two student demonstrators, defendant's "penalty was light in relation to the seriousness of the acts, thereby depriving the ruling of any exemplary value"); see also 42 U.N. ESCOR Comm'n on Hum. Rts., para. 156, U.N. Doc. E/CN.4/2 (1986) (governments must make every effort to investigate allegations of complaints of physical abuse of detainees "so that those who turn out to be responsible may be punished harshly and without any lenience"); id., para. 52 (torture should be punishable "by appropriate penalties which take into account their grave nature"); Report of the Special Rapporteur, Mr. P. Kooijmans, pursuant to Commission on Human on Human Rights resolution 1989/33, 46 U.N. ESCOR Comm'n on Hum. Rts. at 84, para. 272(i), U.N. Doc. E/CN.4/1990/17 (whenever a person is found guilty of torture, "he should be severely punished"); Report by the Special Rapporteur, Mr. P. Kooijmans, pursuant to Commission on Human Rights resolution 1987/29, 45 U.N. ESCOR Comm'n on Hum. Rts., para. 50, U.N. Doc. E/CN.4/17 (1989) ("heavy penalties whenever torture occurs are vitally necessary" in countries where elected governments have replaced repressive regimes): Report of the Working Group on 
That abuse of the pardon power can undermine states' duty to protect citizens from harm has long been recognized. The eighteenth century Italian criminologist Cesare Beccaria made the point this way: "To shew mankind, that crimes are sometimes pardoned, and that punishment is not the necessary consequence, is to nourish the flattering hope of impunity . .."311 Bentham saw in the pardon power the potential for lawlessness:

From pardon power unrestricted, comes impunity to delinquency in all shapes: from impunity to delinquency in all shapes, impunity to maleficence in all shapes: from impunity to maleficence in all shapes, dissolution of government: from dissolution of government, dissolution of political society. ${ }^{312}$

The harmful effects of pardons are compounded when they are granted in response to military demands, thereby undermining the authority of civilian institutions reestablished by prosecutions. ${ }^{313}$

\section{B. Derogation}

Throughout this Article I have answered the claim that prosecutions are destabilizing by asserting: They need not be. The threat of instability is minimized when prosecutions are backed by unambiguous international law whose requirements are confined within principled limits. Still, there may be times when a fragile government lacks the power to comply with even the modest requirements of international law outlined in Section II.A. The situation I have in mind, of course, is one in which the military retains de facto power after relinquishing office, and will not abide a legal accounting for its depredations. When instituting prosecutions would pose a serious threat to vital interests-and not merely provoke military disaffection-can a government be excused from

Enforced or Involuntary Disappearances, 47 U.N. ESCOR Comm'n on Hum. Rts. at 86, para. 408, U.N. Doc. E/CN.4/1991/20 (problem of impunity is compounded by "reticence in the administration of justice"-particularly on the part of military courts-characterized by rare prosecutions, few convictions, and, when violators are convicted, "sentences that, by any standard, are grossly disproportionate to the crime committed."). These views comport with common conceptions of justice. In H.L.A. Hart's words, disproportionate sanctions pose the risk "of either confusing common morality or flouting it and bringing the law into contempt." H.L.A. HART, supra note 296, at 25.

311. C. BECCARIA, supra note 296, at 158-59.

312. Quoted in K. MOORE, supra note 5 , at 35.

313. See Timerman, Fear Returns to Argentina, N.Y. Times, Jan. 5, 1991, at 21, col. 1 (opinion piece); Pardoning Mass Murder in Argentina, N.Y. Times, Jan. 3, 1991, at A20, col. 1 (editorial) (both asserting that Argentine President Saul Menem's pardon of convicted military leaders for human rights crimes will embolden military to place itself above the law). Professor Moore has argued that, "[b]ecause pardons single people out for special treatment, every pardon is potentially a comparative injustice, a violation of the principle of equal treatment under the law." Moore, When Mercy Weakens Justice, N.Y. Times, Aug. 10, 1989, at A23, col. 1 (opinion piece). She argues that the only legitimate use of pardons is to prevent punishment of an innocent person or to "impose" the sentence that the offender deserves, on retributivist grounds, for her offense-in effect, to correct a sentence that was (or has become) inappropriate in light of retributivist-based criteria-and not to serve political or other interests. See K. MOORE, supra note 14. 
its general duty to punish atrocious crimes? The answers provided by international law are, in some respects, unsatisfactory. For as the following analysis makes clear, relevant law may not make adequate provision for situations in which the military occupies an autonomous realm of power.

The three comprehensive conventions analyzed in Part II allow States Parties to derogate from their duties in time of public emergency that threatens the life of the nation when various conditions are satisfied. ${ }^{314}$ Under no circumstances, however, are derogations from the rights to life and freedom from torture permitted. ${ }^{315}$ When applicable, the customary doctrines of state of necessity and force majeure similarly preclude the wrongfulness of a state's failure to comply with its international obligations in exceptional circumstances. ${ }^{316}$ But the prohibitions of torture, disappearances, and extra-legal executions have the status of peremptory norms: ${ }^{317}$ they can never be abrogated. ${ }^{318}$

The question arises, then, whether states' duty to prosecute these crimes should also be treated as nonderogable on the basis that prosecution of violators is necessary to secure the peremptory rights. Authoritative interpretations of the conventions analyzed in Part II offer no clear guidance on this question; the issue has never been squarely addressed. A plausible case can be made in support of either possible position.

While similar considerations would apply to all three comprehensive treaties, the issue is framed most sharply under the American Convention. Article 27(2) provides both that several substantive rights are nonderogable and that "the judicial guarantees essential for the protection of such rights" are likewise nonderogable. ${ }^{319}$ Interpreting this provision, the Inter-American Court

314. International Covenant, supra note 54, art. 4(1); American Convention, supra note 92, art. 27(1); European Convention, supra note 34 , art. 15(1).

315. International Covenant, supra note 54, art. 4(2); American Convention, supra note 92, art. 27(2); European Convention, supra note 34, art. 15(2). As noted earlier, none of these conventions explicitly proscribes disappearances as such. Accordingly, the right against forced disappearances is not explicitly made non-derogable. The draft Inter-American Convention on the Forced Disappearance of Persons, supra note 210, explicitly prohibits suspension of judicial guarantees necessary to secure protection from forced disappearances. See infra note 324.

316. These doctrines apply to obligations imposed both by customary law and by conventions that do not have an explicit derogation clause or a provision governing States Parties' obligations in the event of force majeure. See T. MERON, supra note 57, at 219 n.261; [1978] 2 Y.B. INT'L L. COMM'N (pt. 1), at 74, para. 32; 77, para. 39, U.N. Doc. A/CN.4/315 (1977) (force majeure). Their application to conventions that have derogation clauses is addressed in [1980] 2 Y.B. INT'L L. COMM'N (pt. l) at 45, para. 67; 51, Draft Article 33 (state of necessity), U.N. Doc. A/CN.4/318/Add.5-7 (1980).

317. See supra text accompanying note 195.

318. Although the principal effect of a rule's status as $j u s$ cogens is that it "cannot be set aside by treaty or acquiescence but only by the formation of a subsequent customary rule of contrary effect," I. BROWNLIE, supra note 57 , at 513 , a peremptory norm's non-derogability in this sense also connotes its non-derogability for purposes of applying doctrines of exception, such as state of necessity. See T. MERON, supra note 60, at 60 .

319. Although the other comprehensive treaties do not explicitly provide that judicial guarantees cannot be suspended if they are essential to the protection of non-derogable rights, it is implicit in the conventions' recognition of rights as non-derogable that States Parties must do that which is necessary to secure the rights. 
has concluded that States Parties to the American Convention cannot suspend individuals' right to seek habeas corpus. ${ }^{320}$ Since the Court has found punishment to be a necessary part of States Parties' duty to ensure rights under the Convention, ${ }^{321}$ States Parties arguably may not be able to derogate from their duty to prosecute violations of nonderogable rights.

Although plausible, this interpretation of the American Convention is not inevitable. Habeas corpus and criminal prosecution could be distinguished for purposes of determining whether derogation is permissible. Habeas corpus can avert imminent or further harm; it can, for example, be used to locate a person who has "disappeared" and thus secure her from physical danger, or to prevent a detainee who has been tortured from suffering further abuse. ${ }^{322}$ In contrast, criminal prosecution cannot prevent the specific act for which punishment is sought; it can only deter future instances of the offense. ${ }^{323}$ Thus, while prosecutions play a necessary part in States Parties' fulfillment of their duty to ensure fundamental rights, they may not be deemed "essential" for the protection of those rights for purposes of Article 27(2). Applying similar logic, the duty to institute criminal proceedings pursuant to other conventions may be derogable, at least in principle. ${ }^{324}$

Still, in view of the consistent recognition by international bodies that prosecution is necessary to secure certain nonderogable rights, a rule of law allowing states to derogate from the duty to prosecute violations of those rights would produce untenable results. Such a rule would have international law assert on the one hand that the rights to life, freedom from torture, and freedom from forced disappearances are nonderogable, and on the other hand that, under certain circumstances, states need not do that which is necessary to secure the rights.

Similar issues arise in applying the customary doctrine of state of necessity. ${ }^{325}$ The International Law Commission's draft articles on state responsibility

320. Judicial Guarantees in States of Emergency (Arts. 27(2), 25 and 8, American Convention on Hum. Rts.), Inter-Am. Ct. H.R. (advisory opinion), O.A.S. Doc. OC-9/87 (ser. A) No. 9 (1987).

321. See Part II, § C.2.

322. See Judicial Guarantees in States of Emergency (Arts. 27(2), 25 and 8, American Convention on Hum. Rts.), Inter-Am. Ct. H.R. (advisory opinion), O.A.S. Doc. OC-9/87 (ser. A) No. 9, para. 35 (1987).

323. It is precisely this function that underlies the duty to punish certain human rights violations. See supra text accompanying note 285 .

324. The draft Inter-American Convention on the Forced Disappearance of Persons, supra note 210, which requires States Parties to prosecute persons responsible for forced disappearances, provides that "States Parties shall not suspend any judicial guarantee including habeas corpus as a means of determining the whereabouts of a detainee, his or her state of health or the warrant from the authority leading to the arrest," even during a state of emergency. Id. art. 15. It does not, however, explicitly prohibit suspension of criminal prosecutions. Similarly, while the Convention Against Torture, supra note 92, requires States Parties to prosecute torture, its non-derogation provision does not explicitly address the duty to prosecute, providing only that "[n]o exceptional circumstances whatsoever . . . may be invoked as a justification of torture." $I d$., art. 2(2). Article 5 of the Inter-American Convention to Prevent and Punish Torture, supra note 92, establishes a similar rule.

325. Although circumstances in which the state of necessity doctrine applies are similar to those in which derogation is permitted under the comprehensive human rights treaties, the parameters of the conventional rules of derogation and the customary state of necessity doctrine may not be identical. See 
frame the doctrine this way: the state of necessity doctrine precludes the wrongfulness of an act of a state "not in conformity with an international obligation" if "the act was the only means of safeguarding an essential interest of the State against a grave and imminent peril." ${ }^{326}$ This justification is not available, however, "if the international obligation with which the act of the State is not in conformity arises out of a peremptory norm of general international law." ${ }^{327}$ As the earlier discussion makes clear, the customary duty to prosecute torture, disappearances, and extra-legal executions "arises out of" rights that have the status of peremptory norms. ${ }^{328}$

Even if the duty to prosecute certain human rights crimes were derogable in principle, states could rarely justify suspension of prosecutions. Both the state of necessity doctrine and the derogation provisions of human rights treaties establish a high threshold for application, requiring a grave and imminent threat to an essential state interest. ${ }^{329}$ And when the applicable threshold is established, States Parties to the comprehensive treaties may derogate only "to the extent strictly required by the exigencies of the situation." ${ }^{330}$ As noted, the state of necessity doctrine justifies noncompliance with international obligations only if the state's action "was the only means" of safeguarding an essential state interest against grave and imminent peril. ${ }^{331}$ The force majeure doctrine also has a high threshold of application. The ILC's draft articles on state responsibility frame the force majeure rule in the following terms: "The wrongfulness of an act of a State not in conformity with an international obligation ... is precluded if the act was due to an irresistible force ... which made it materially impossible for the State to act in conformity with that obligation . ..."332 Under each of these standards, governments would not be excused

Meron, On a Hierarchy of International Human Rights, 80 AM. J. INT'L L. 1, 20 (1986).

326. Draft article 33(1), [1980] 2 Y.B. INT'L L. COMM'N (pt. 2) at 33, U.N. Doc. A/35/10 (1980).

327. Id., Drafi article 33(2)(a). Although the IlC does not specify what it means by "arises out of," a common sense interpretation is that which "is reasonably necessary to secure the observance of."

328. See supra text accompanying notes $195,198-99$. As noted earlier, that duty is significantly less exacting than the corresponding duty established by various human rights conventions-except, perhaps, in the special circumstances surrounding political transitions. See supra Part III, A.2.

329. See supra text accompanying notes 314,326 . Bodies responsible for supervising compliance with the comprehensive human rights conventions have made clear that derogation is not justified if a threat is not sufficiently imminent or grave, even if it has some basis in fact. See, e.g., The Greek Case, 1969 Y.B. EUR. CONV. ON HUM. RTS. 71-76, paras. 152-65 (Eur. Comm'n of Hum. Rts.).

330. International Covenant, supra note 54, art. 4(1); European Convention, supra note 34, art. 15 (1). The corresponding language in Article 27(1) of the American Convention, supra note 92, is: "to the extent and for the period of time strictly required by the exigencies of the situation . ..." See Jorge Landinelli Silva v. Uruguay, Comm. No. R.8/34, 36 U.N. GAOR Supp. (No. 40) Annex XII, para. 8.4, U.N. Doc. A/36/40 (1981) (Human Rights Committee asserts that, even if situation of emergency existed in Uruguay, measures taken by government exceeded those that could be justified as necessary to restore peace and order).

331. See supra text accompanying note 326.

332. Draft article 3l(I), [1980] 2 Y.B. INT'L L. COMM'N (pt. 2) at 33, U.N. Doc. A/35/10 (1980). Although more commonly applied to acts of nature rendering compliance with international duties impossible, the force majeure doctrine has sometimes been applied to situations of insurrection causing injury to aliens. See I. BRowNLIE, supra note 57, at 466; [1978] 2 Y.B. INT'L L. COMM'N (pt. 1) at 106-24, paras. 162-246, U.N. Doc. A/CN.4/315 (1977). The appropriateness of the latter application has been questioned 
from their duty to prosecute human rights violations merely to placate restive military forces; the excuses are available only to avert a threat to the life of a nation or, in the case of force majeure, when compliance is rendered materially impossible.

It is unclear, moreover, whether various excuses for noncompliance would apply even if military conduct imperiled an essential state interest. The ILC's draft articles on state responsibility assert that a state of necessity may not be invoked to justify a breach of an international duty "if the State in question has contributed to the occurrence of the state of necessity." 333 Similarly, the ILC asserts that the force majeure rule does not apply "if the State in question has contributed to the occurrence of the situation of material impossibility." 334 Under the law of state responsibility, conduct of a state organ-including the military-is attributable to the state. ${ }^{335}$ Thus if a state failed because of military intimidation to punish atrocious crimes that it was otherwise required to prosecute, the state would be in breach of its international obligations. ${ }^{336}$

A decision of the European Commission of Human Rights suggests a different approach under the derogation clause of the European Convention. In The Greek Case, the Commission rejected the applicant states' argument that the revolutionary military government of Greece could not invoke the Convention's derogation provision because it had, by overthrowing the previous gov-

on the basis that general rules governing state responsibility for injury to aliens caused by non-state actors, such as those requiring states to exercise due diligence, determine the responsibility of the state without having to resort to such doctrines as force majeure. See C. EAGLETON, supra note 95, at 125-26.

333. Draft article 33(2)(c), [1980] 2 Y.B. INT'L L. COMM'N (pt. 2) at 33, U.N. Doc. A/35/10 (1980). See also [1978] 2 Y.B. INT'L L. COMM'N (pt. 1) at 73, para. 29, U.N. Doc. A/CN.4/315 (1977).

334. Drafi article 31(2), [1980] 2 Y.B. INT'L L. COMM'N (pt. 1) at 33, U.N. Doc. A/35/10 (1980); see also [1978] 2 Y.B. INT'L L. COMM'N (pt. 1) at 69, para. 15, U.N. Doc. A/CN.4/315 (1977). Indeed, publicists have distinguished the force majeure and state of necessity doctrines on the basis that the former involves conduct that is "involuntary," having been brought about by an external and irresistible force, while the latter involves a deliberate course of state action chosen to avert imminent harm to the life of the state. See [1978] 2 Y.B. INT'L L. COMM'N (pt. 1) at 72-74, paras. 25-30, U.N. Doc. A/CN.4/315 (1977); [1980] 2 Y.B. INT'L L. COMM'N (pt. 1) at 14, paras. 1-2, U.N. Doc. A/CN.4/318/Add.5-7 (1980).

335. T. MERON, supra note 57, at 155-56. This is true even if the state organ exceeded its competence or contravened its instructions pursuant to national law. Id. at 156-57; Draft article 10, [1975] 2 Y.B. INr'L L. COMM'N 60, U.N. Doc. A/10010/Rev.1 (1975); see also id. at 66, para. 15.

336. See [1980] 2 Y.B. INT'L L. COMM'N (pt. 1), at 111-112, para. 20, U.N. Doc. A/CN.4/330 (1980) (noting similarity of rules of attribution for purposes of establishing state responsibility and determining whether conduct "contributing to" material impossibility restores full responsibility when force majeure doctrine would otherwise preclude the wrongfulness of a state's conduct). This interpretation of international law is reinforced by the views of several U.N. Rapporteurs and Representatives. For example, the Special Representative on El Salvador has repeatedly faulted the Salvadoran judiciary for failing to pursue prosecutions of military personnel who committed extra-legal executions--despite his acknowledgment that Salvadoran judges face a serious threat of assassination and other forms of intimidation by Salvadoran armed forces. See, e.g., Final report on the situation of human rights in El Salvador, submitted to the Commission on Human Rights by Professor José Antonio Pastor Ridruejo in fulfillment of the mandate conferred under Commission resolution 1982/28, 39 U.N. ESCOR Comm'n on Hum. Rts. at 39, para. 96; 46, para. 119, U.N. Doc. E/CN.4/1983/20. 
ernment, brought about the revolutionary situation upon which it based its claim of entitlement to derogate. ${ }^{337}$

One can fairly question whether the widely recognized rules formulated by the ILC are appropriate in the circumstances prevailing in many transitional societies. Legal rules attributing military conduct to the state presuppose the government's ability to control its armed forces. ${ }^{338}$ But when countries emerge from a protracted period of military rule, the armed forces often continue to occupy a large realm of autonomous power, exerting more control over the civilian government than it asserts over them. ${ }^{339}$ In these circumstances, a rule requiring civilian authorities to prosecute armed forces may seem inappropriate, and even nonsensical-if not downright dangerous.

Yet the alternative-excusing states from compliance with their human rights obligations-also poses troubling prospects. If transitional governments were excused from their international duties when military obstruction accounts for their noncompliance, international law would effectively reward the military's behavior. ${ }^{340}$ Also, a formal recognition that the civilian government is, in effect, rendered powerless by the armed forces would undercut the legitimacy of the elected government when its authority is already imperiled. ${ }^{341}$

While applicable rules are probably best clarified on a case-by-case basis, future legal developments should be guided by one overarching concern: rules governing derogation should be fashioned to provide incentives for governments to assert control over their armed forces. Customary law governing state responsibility for injury to aliens caused by insurgent forces may offer a productive analogy. International arbitral tribunals have found or intimated that the wrongfulness of a state's noncompliance with international duties toward

337. The Greek Case, 1969 Y.B. EuR. Conv. ON HUM. RTs. 31-32, paras. 58-60 (Eur. Comm'n of Hum. Rts.). In reaching this conclusion, the Commission also rejected the respondent's claim that the Commission could not pass judgment on its conduct since it was a revolutionary government. See id. at 31, para. 56. The Commission found, however, that the circumstances prevailing at the time of the Greek government's derogation did not pose a sufficiently imminent and grave threat to justify its derogations. See id. at 71-76, paras. 152-65; 100, paras. 206-07.

338. Cf. C. EAGLETON, supra note 96, at 26 ("When a state has been recognized by the community of nations, it is presumed to be capable of exercising the rights and duties of membership in that community."). Moreover the reasons why international law generally holds states to a high standard of accountability for the behavior of their armed forces may not be fully pertinent to the circumstances considered here. It is unclear whether standards of strict accountability designed, inter alia, to protect citizens of one state from conduct by organs of another state during international armed conflict are equally relevant when applied to protect the rights of citizens vis-a-vis their own government. See T. MERON, supra note 57, at 161-62.

339. See supra text accompanying notes $3,27-32$. This has been notably true of Guatemala and El Salvador since those countries' formal transition from military to civilian rule in the mid-1980's.

340. The right of derogation has been subject to substantial abuse by governments. See T. MERON, supra note 60, at 53. See generally N. Questiaux, Study of the Implications for Human Rights of Recent Developments Concerning Situations Known as States of Siege or Emergency, U.N. Doc. E/CN.4/Sub.2/198$2 / 15$.

341. Cf. A. JAMES, SOVEREIGN STATEHOOD 127-29 (1986) (noting reticence of other states to withdraw formal recognition from "collapsing states"). For a thoughtful analysis of these issues, see Eric Lasker, Possible Defenses to a 'Transitional Government's Prosecutorial Obligation Under International Human Rights Law (Jan. 17, 1989) (unpublished manuscript on file with author). 
aliens might be precluded if the injury were caused by revolutionary forces over which the government could not assert control. ${ }^{342}$ To avoid liability, a state has had to establish that it exercised due diligence in seeking to prevent the situation that made compliance with its international duties impossible. ${ }^{343}$ This has been treated as a question of fact, to be determined on a case-by-case basis, ${ }^{344}$ and the state's efforts to control revolutionary forces by punishing their crimes have been deemed relevant to the analysis. ${ }^{345}$

Although these issues merit further study, ${ }^{346}$ the difficulty of satisfactorily addressing prosecution-related risks through doctrines of exception underscores the importance of interpreting general legal standards requiring prosecution in a manner that accommodates constraints commonly faced by transitional governments. As argued earlier, governments should be able to discharge their legal duties without provoking the type of crisis that might, under various rules of exception, justify noncompliance.

\section{FutURE DEVELOPMENTS IN THE LAW}

In a period when democracies have replaced dictatorships in dozens of societies, many successor governments have failed to establish criminal accountability for violations of the recent past. ${ }^{347}$ This sobering pattern raises the question whether further elaboration of international standards is desirable ${ }^{348}$

342. E.g., J.N. Henriquez (Netherlands/Venezuela), Mixed Claims Comm'n (1903), 10 REP. INT'L ARB. AWARDS 714-17 (1903); In re Gill (Great Britain v. Mexico), 6 Ann. Dig. 203 (British-Mexican Claims Tribunal 1931-32), 5 REP. INT'L ARB. AWARDS 157, 159 (1931).

343. See C. EAGLETON, supra note 96, at 146.

344. Id.

345. According to Eagleton, "the grant of amnesty to insurgents . . . has sometimes been regarded [by arbitral tribunals] as revealing the lack of a sufficient desire on the part of the government to repress the rebellion." Id. at 151; see also I. BROWNLIE, supra note 57, at 454. In the Gill case, the British-Mexican Claims Tribunal asserted that, when conduct of revolutionaries causing injury to aliens was brought to a government's attention, or was so notorious that the government could presume to have known of it, and it was not shown that the government "took any steps to suppress the acts or to punish those responsible," the Commission could assume "that strong prima facie evidence exists of a fault on the part of the authorities." In re Gill, supra note 342, at 158 . Others have suggested that states can be presumed to have exercised due diligence to supress an insurrection, though such a presumption can be overcome by evidence to the contrary. See I. BROWNLIE, supra.

346. While troubling, the concerns addressed in this section would rarely be determinative of a state's legal duties. The derogation clauses of conventions and the doctrines of necessity and force majeure justify non-fulfillment of an international obligation only during the period of actual emergency or impossibility. See [1978] 2 Y.B. INT'L L. COMM'N (pt. 1) at 69, para. 13, U.N. Doc. A/CN.4/315 (1977) (force majeure); [1980] 2 Y.B. INT'L L. COMM'N (pt. 1) at 20, para. 14, U.N. Doc. A/CN.4/3I8/Add.5-7 (1980) (state of necessity). Since criminal prosecutions often extend over protracted periods, it should rarely, if ever, be necessary for a government formally to suspend implementation of a duty to prosecute human rights offenders. Instead, by their nature criminal proceedings allow governments the flexibility they may need to adjust the timing of prosecutions to avoid exacerbating political tensions.

347. See supra note 36.

348. Problems relating to implementation of human rights conventions have often been addressed by developing new declarations and conventions designed to improve compliance with duties that have been inadequately implemented. For example, the European Convention for the Prevention of Torture and Inhuman or Degrading Treatment or Punishment, adopted Nov. 26, 1987, E.T.S. 126, Misc. 5 (1988), reprinted in 27 I.L.M. 1152 (1988) (entered into force Feb. 1, 1989), establishes obligations designed to 
or, instead, whether the gap between duty and compliance can effectively be narrowed by invigorating efforts to implement current law. ${ }^{349}$

The two options are not mutually exclusive, and the values promoted by prosecutions ${ }^{350}$ may be best served if both approaches are pursued. Efforts to secure compliance with current law can only be strengthened by states' adherence to conventions that render explicit the duty to prosecute grave violations of physical integrity. ${ }^{351}$

While the Convention Against Torture serves this function, similar international conventions on extra-legal executions and disappearances should be adopted ${ }^{352}$ Like the Convention Against Torture, the new conventions should define the conduct that States Parties must criminalize; explicitly require States Parties to investigate credible allegations that the crimes have occurred, even if no formal complaint has been filed, and to prosecute those implicated by the investigation or extradite them for trial in another country; and require that national legislation provide for appropriately severe penalties.

The proposed treaties should include provisions designed to ensure prosecution in the event that a State Party abrogates the duties it has undertaken. To this end, future conventions should require States Parties to afford victims, their survivors, or their legal representatives a means of initiating a criminal proceeding in the event that the state fails to do so, or of seeking review of a prosecutor's determination not to press charges. ${ }^{353}$ The conventions should also estab-

eradicate torture-a practice prohibited by the European Convention, supra note 34, which was adopted in 1950. For other examples, see supra note 92 . The newer instruments have generally been thought to reinforce the earlier-established legal norms, and not implicitly to call their validity into question. The reiteration of a rule in numerous international instruments has, in fact, often been cited as evidence that the rule has acquired the status of customary law. See, e.g., Filartiga v. Peña-Irala, 630 F.2d 876, 882-84 (2d Cir. 1980).

349. A case involving a challenge to Suriname's amnesty law, referred to the Inter-American Court in August 1990, will afford the Court an important opportunity to affirm the duty to punish extra-legal executions pursuant to the American Convention. See supra note 5.

350. See Part I, A.

351. Proposed rules of international law that would secure important values should not be rejected because they would require some governments to aspire to standards they have generally failed to satisfy -an argument advanced by some opponents of new law requiring prosecution. It is precisely the point of human rights law to promote a higher standard of conduct than that which prevails in many countries when the law comes into force. $C f$. W. MOBERLY, RESPONSIBILITY: THE CONCEPT IN PSYCHOLOGY, IN THE LAW, AND IN THE CHRISTIAN FATTH 23 (1956) ("In many circumstances to expect and to exact a high standard is the most likely way to get it."). Ideally, new legal norms should raise standards of conduct prevailing in countries where generally-accepted principles are routinely violated, without establishing standards that cannot reasonably be satisfied by those subject to the law. I am indebted to Professor Henry B. Hansmann for this insight.

352. The following discussion considers only provisions relating to investigation, prosecution and punishment that should be included in future conventions. Any specialized conventions concerned with extralegal executions or disappearances should, of course, set forth other means of preventing and remedying these abuses, including the assurance of effective civil remedies.

353. Many countries' legal systems enable individuals who have a direct interest in a case to initiate criminal proceedings or to challenge the public prosecutor's decision not to press charges, and these procedures help check abuses of prosecutorial discretion. See Damaška, supra note 264, at 135. Some potential adherents to the proposed conventions-particularly countries whose legal systems allow broad prosecutorial discretion and do not enable private parties to initiate criminal proceedings-may, of course, be unwilling to accept the proposed provision. This possibility should not, however, deter its inclusion in 
lish an oversight body that is empowered, inter alia, to receive complaints from, or on behalf of, individuals who claim that their convention-based rights have been violated. Together, these provisions would enable victims to seek the assistance of an international body to press their governments to initiate prosecutions when malfeasance accounts for a state's failure to do so. ${ }^{354}$

The proposed conventions should also authorize the oversight body to 1) initiate an investigation of apparently well-founded reports that a State Party has systematically violated the convention and failed to prosecute the offenders, even if no complaint has been received; ${ }^{355}$ and 2 ) receive inter-state complaints alleging such a pattern. ${ }^{356}$ While the first power is not yet common among bodies that monitor compliance with human rights conventions, it would not be exceptional. The Committee that monitors compliance with the Convention Against Torture can initiate investigations of this sort; ${ }^{357}$ this approach signals the direction that should be taken in future conventions. By declaring a state to be in breach of its treaty obligations and urging corrective action, the oversight body would provide a measure of accountability and build international pressure in support of prosecutions that is now lacking. ${ }^{358}$

The proposed conventions should also explicitly require States Parties to ensure protection of complainants and witnesses, to investigate allegations of intimidation of participants in legal proceedings, and to prosecute those who are responsible. Future conventions should also explicitly prohibit States Parties from adopting laws or issuing decrees that preclude criminal punishment of persons who commit atrocious crimes. ${ }^{359}$ Following the example of the Con-

a convention; States Parties unwilling to accept the obligation could enter a reservation to the relevant article.

354. The practice of such bodies as the Human Rights Committee and the Inter-American Commission of urging states to investigate particular human rights violations and to bring to justice those who are responsible, see supra text accompanying notes 147-60, 176-77, establishes a foundation for allowing individuals to seek the assistance of an international body in compelling governments to initiate criminal proceedings in particular cases. Such a body would, of course, only be able to accept complaints from victims alleging a violation by a State Party that had recognized the body's competence.

355. Because many governments have been more inclined to ratify than to comply fully with human rights conventions, adherents to the proposed conventions would likely include some governments that systematically commit serious violations.

356. If there were any viable prospect of the creation of an international criminal court, it would also be desirable to include a provision recognizing the tribunal's competence over systematic violations of the conduct proscribed in the proposed conventions. As noted earlier, however, proposals to establish such a court have languished at the United Nations. See supra note 86.

357. Article 20 of the Convention Against Torture, supra note 67, authorizes the Committee Against Torture to initiate an investigation when it "receives reliable information which appears to it to contain wellfounded indications that torture is being systematically practised in the territory of a State Party."

358. Cf. T. MERON, supra note 57, at 205-07 (declaratory judgment is an especially appropriate form of relief in cases initiated by inter-state petitions alleging a system or pattern of human rights violations; "[a] clear declaration that a government's conduct violates human rights sensitizes national and international public opinion, thus bringing pressure to bear on the government to conform its conduct to international standards."). Although the "sanction" of publicity may seem limp, it has in fact proved to be one of the most effective means of promoting state compliance with internationally-recognized human rights standards. See Orentlicher, supra note 93 , at 84.

359. The draft Inter-American Convention on the Forced Disappearance of Persons, supra note 210, contains such a provision. Id., art. 8 . 
vention Against Torture, future specialized treaties should establish universal jurisdiction over the proscribed conduct. ${ }^{360}$ Finally, the conventions should provide that the crimes they define shall not be considered "political offenses" for purposes of extradition.

Never has the time been more auspicious to develop such conventions. As countries emerge from periods of sweeping state violence, many of the new governments are assuming international commitments to help assure that their nations never again descend into an all too familiar chasm of lawlessness and repression. ${ }^{361}$

\section{CONCLUSION}

In a wide array of countries the specter of torture, political murder, and forced disappearance has been dispelled by the dawning of freedom and the revival of judicial process. But the transitions have rarely been smooth, and the fledgling democracies face formidable challenges as they seek to balance the demands of justice against the continuing threat of destabilizing force.

In these circumstances, can the insertion of this or that provision in an international treaty possibly make a difference? For a new government precariously perched atop a restless and long-oppressed polity, with the torturers still controlling the guns, the threat of a coup may seem all too real. International law seems not so much remote as beside the point.

And yet. If the international community cannot prevent, at least it must not condone. Its words of censure or approval eventually filter through. For over a decade the dissidents of Eastern Europe recited the human rights promises of the Helsinki Final Act. With every recital the legitimacy of the governments that had made and broken those promises crumbled a little more.

360. While states have been reluctant to assert universal jurisdiction to punish human rights crimes committed in another country, it is conceivable that prosecution of some crimes by a "foreign" government would be acceptable to both the prosecuting state and the government of the state where the crime occurred. The Panamanian government of Guillermo Endara supported prosecution of General Manuel Antonio Noriega (on drug-trafficking charges) in the United States, while the Philippine government of Corazon Aquino supported the prosecution (on corruption charges) of former President Ferdinand Marcos-who died before his case went to trial-and his wife Imelda in the United States. Still, enduring concerns about sovereignty are likely to prevent frequent resort to universal jurisdiction as a basis for prosecuting human rights crimes. It is noteworthy that, despite the Aquino government's support for the U.S. prosecution of Imelda Marcos, the presiding judge questioned the propriety of prosecuting Mrs. Marcos in a U.S. court for malfeasance allegedly committed in the Philippines, and jurors who acquitted Mrs. Marcos indicated that they shared this concern. See The 'Wrong' Court: Marcos Acquittal Is Seen as Reaction of Jury to Hearing Manila Case in U.S., N.Y. Times, July 3, 1990, at B3, col. 5.

361. Among the first acts of governments that have replaced dictatorships in such countries as Argentina, the Philippines and Uruguay has been adherence to international human rights conventions. See Nino, The Human Rights Policy of the Argentine Constitutional Government: A Reply, 11 YALE J. INT'L L. 217, 220-21 (1986); LAWYERS COMMITTEE FOR HUMAN RIGHTS, VIGILANTES IN THE PHILIPPINES: A THREAT TO DEMOCRATIC RULE X (1988); Zalaquett, supra note 8 , at 38,66 n. 16 . 


